\title{
Het koningschap in België in de eenentwintigste eeuw
}

Jan Velaers

\section{Inleiding}

\section{De monarchie van meet af aan republikeins}

-I. Het Belgisch grondwettelijk recht over de monarchie vertoont een grote stabiliteit. Dat laat zich verklaren doordat de grondwetgever al in I83I brak met de autocratische monarchie en opteerde voor een 'republikeinse monarchie'. In het Nationaal Congres liet men daarover geen twijfel bestaan. Velen hadden het over 'une monarchie républicaine', ' 'une monarchie aussi républicaine que possible'. ${ }^{2}$ De Belgische monarchie is een constitutionele monarchie: de Koning legt de eed van trouw aan de grondwet af (art. 9I, derde lid GW) en heeft geen andere machten dan degene die de grondwet of de wetten hem uitdrukkelijk toekennen (art. I05 GW). Hij heeft ook geen persoonlijke macht. 'Geen akte van de Koning kan immers gevolg hebben, wanneer ze niet mede ondertekend is door een minister die daardoor alleen reeds ervoor verantwoordelijk wordt' (art. Io6 GW). 'De persoon van de Koning is onschendbaar, zijn ministers zijn verantwoordelijk', zo luidt het (art. $88 \mathrm{GW}$ ). Van meet af aan ging het ook om een representatieve monarchie. Zonder de volksvertegenwoordiging in Kamer en Senaat kunnen geen wetten worden gestemd, geen belastingen geheven, geen begrotingen goedgekeurd en hebben de verdragen geen gelding. Dat het ook een parlementaire monarchie zou zijn, was in I83 I niet zo duidelijk. De Koning benoemt en ontslaat 'zijn' ministers, zo luidde het en zo luidt het nog steeds (art. $96 \mathrm{GW}$ ). Nergens staat dat zij ook het vertrouwen van de meerderheid in het parlement dienen te krijgen. Een aantal leden van het Nationaal Congres

* Jan Velaers is gewoon hoogleraar aan de Universiteit Antwerpen en assessor in Raad van State, afdeling Wetgeving.

I Ch. Vilain XIIII, I9 november I830 E. Huyttens, Discussions du Congrès National de Belgique, I830-I83I, I, p. 200.

2 J.B. Nothomb, I9 november I830, ibidem, p. I92. De Stassart had het over 'des institutions vraiment libérales, des institutions presque républicaines si l'on veut', (I9 november I830, p. II6). 'Nous avons admis dans la Constitution une combinaison des principes monarchique et républicain,' aldus Raikem (I9 juli i831, p. 633). Abbé Dehaerne stelde dat 'la monarchie représentative n'est autre chose qu'une république déguisée.' (I4 december I830, p. 474). 'Nous faisons plutôt une république royale qu'une monarchie républicaine', verklaarde Charles Lehon (6 februari I83I, p. 562). 
stelde dat de Koning de ministers kon kiezen die hij vertrouwde. ${ }^{3}$ De meest luciden, zoals bv. Joseph Lebeau, zagen echter meteen in dat de echte Governmentmaking Power onontkoombaar aan de volksvertegenwoordiging ${ }^{4}$ zou toekomen, dat de regering het beleid zou moeten voeren dat een meerderheid in het parlement wenste en dat niet de Koning, maar de ministers de dienst zouden uitmaken. Lebeau verklaarde: 'La Royauté n'est pas, à proprement parler, un pouvoir. Comment dire qu'il y ait pouvoir, lorsque toute faculté d'agir est interdite sans l'assentiment d'autrui? Telle est la position de la Couronne, assujettie qu'elle est par le contreseign à la volonté du conseil. Toute l'action propre de la couronne gît dans le choix du cabinet, mais on a vu que ce choix lui est imposé. 5 Al na enkele jaren, na het ontstaan van de politieke partijen, was het duidelijk dat Lebeau gelijk kreeg. In I846 werd de liberale partij opgericht. In 1847 slaagde die erin een meerderheid van de zetels in het parlement te veroveren, zodat de Koning zich verplicht zag een liberale regering te aanvaarden. Daarmee was het parlementair systeem een feit.

\section{Een evolutie buiten de tekst van de grondwet}

-2. Democratie en monarchie evolueerden ook later uiteraard nog. Het koningschap van Albert I is nauwelijks te vergelijken met dat van Albert II. De lijn van de evolutie is duidelijk: de Koning raakte steeds meer op de achtergrond. Die evolutie voltrok zich zonder dat de artikelen in de grondwet over de monarchie ingrijpend werden gewijzigd. Alleen de bepalingen over de troonopvolging werden tot tweemaal toe herzien. In I893 werd, op uitdrukkelijk verzoek van Leopold II, de instemming van de Koning met het huwelijk van de prinsen als voorwaarde gesteld om het recht op de troon te behouden (art. 85, tweede lid GW) Ook werd voorzien in de mogelijkheid voor de Koning om bij gebreke aan mannelijke troonopvolgers zelf, met instemming van de Kamers, een opvolger aan te duiden (art. $86 \mathrm{GW}$ ). Bijna honderd jaar later, in I99I, werd de Salische wet opgeheven. Ook vrouwen kwamen voortaan voor de troon in aanmerking. Ten slotte werden in 1993 bepalingen over de legislatuurregering en het legislatuurparlement in de grondwet ingeschreven, die ook een weerslag hebben op de bevoegdheid van de Koning om een eerste minister te benoemen en de Kamers te ontbinden. We komen er later nog op terug. Anders dan Nederland, dat met een herziening van de grondwet in 1983 de bepalingen inzake het koningschap heeft 'versoberd, verduidelijkt en gemoderniseerd'6 door o.m. de machten

3 Zo stelde Lehon: 'Il faut laisser au chef de l'Etat la plus grande latitude pour le choix des dépositaires de son pouvoir. Sous un régime franchement constitutionnel, en présence de deux chambres électives, avec la discussion publique de toutes les lois, et une véritable responsabilité ministérielle, le chef de l'Etat est le plus intéressé au bon choix de ses ministres.' Le Hon in E. Huyttens, II, p. 220.

4 Lebeau: 'La Chambre, une fois composée, confirme, modifie ou renvoie le ministère selon le degré de confiance ou de défiance qu'il lui inspire. La chambre élective, ouvrant et fermant à volonté la bourse des contribuables, tient dans sa main la destinée du cabinet; elle impose à la couronne ses exclusions et ses choix; elle élit donc en réalité quoique indirectement, le ministère tout entier.' E. Huyttens, I, p. 208.

5 E. Huyttens, I, p. 208.

6 Notitie 'over het koningschap' van minister-president W. Kok, 2000. 
niet langer aan de Koning toe te wijzen, maar aan de regering, die wordt gevormd door de koning en de ministers, ademt de Belgische grondwet nog steeds de verhoudingen uit die in I83 I bestonden. Ze ziet er nog steeds uit als 'une constitution du temps de Louis-Philippe'? De Koning staat nog steeds centraal. De bevoegdheden worden aan hem toegewezen, niet aan de regering. De wetgevende macht wordt gezamenlijk uitgeoefend door de Koning, de Kamer van Volksvertegenwoordigers en de Senaat (art. $36 \mathrm{GW}$ ), terwijl de uitvoerende macht bij de Koning berust (art. 37). De overige bepalingen van de grondwet wijzen de machten eveneens toe aan de Koning, niet aan de regering. Die wordt in de grondwet nauwelijks genoemd. ${ }^{8}$ Ook van de ministers is er nauwelijks een spoor te bekennen.

-3. Het is op grond van het ongeschreven staatsrecht, van grondwettelijke gewoonten en conventies dat men kan stellen: er staat niet wat er staat, je mag het niet letterlijk nemen, ook in België geldt het adagium 'de Koning heerst, maar regeert niet'. In I949, tijdens de koningskwestie, werd bij regentsbesluit een commissie ingesteld om advies uit te brengen 'over de toepassing van de grondwettelijke beginselen betreffende de uitoefening van de prerogatieven van de Koning en over de verhoudingen der grote grondwettelijke machten onderling'. Het verslag van deze commissie $^{9}$ - die we hierna de commissie-Soenens zullen noemen, naar haar voorzitter L. Soenens, de toenmalige eerste voorzitter van het Hof van Cassatie - is nog steeds een belangrijk document over dit ongeschreven grondwettelijk recht. Vooral de onschendbaarheid van de Koning, zijn onbekwaamheid om alleen te handelen, de ministeriële verantwoordelijkheid en hun onderlinge samenhang, staan erin centraal. 'De onschendbaarheid van de persoon van de Koning zal des te nuttiger zijn voor de monarchie en voor het land, als de regel van de onbekwaamheid voor de Koning om alleen te handelen, beter zal nagekomen worden', zo luidt het. De ministeriële verantwoordelijkheid heeft een ruime draagwijdte. Immers: 'Elke daad van de koning die rechtstreeks of onrechtstreeks een politieke weerslag kan hebben moet door een minister gedekt worden'. ${ }^{\text {ro }}$ Verder zijn er hoofdstukken over 'de benoeming en afzetting van ministers', het 'bevelhebberschap over het leger' en het 'kabinet van de Koning', aangelegenheden waarover er tijdens de regeerperiode van Leopold III discussie was ontstaan.

A. Mast, 'Une Constitution du temps de Louis Philippe', Rev. Dr. Publ. Sc. Pol., 1957, p. 987-Iozo.

8 Hoofdstuk III van de Grondwet handelt over 'De Koning en de federale Regering'.

9 Verslag van de Commissie ermede belast een met redenen omkleed advies uit te brengen over de toepassing van de grondwettelijke beginselen betreffende de uitoefening van de prerogatieven van de Koning en over de verhoudingen der grote grondwettelijke machten onderling, B.S., 6 augustus 1949. Zie ook A. Alen en J. Dujardin, Casebook Belgisch Grondwettelijk Recht, Brussel, Story Scientia, 1986, p. 373-390.

Io Zodra het optreden van de koning het staatsbelang raakt of een weerslag heeft op de beleidsdomeinen waarvoor de overheid verantwoordelijkheid draagt, is de ministeriële verantwoordelijkheid in het geding. 


\section{Geen debat over het koningschap ... of toch?}

-4. Vergelijkbare documenten zijn er later niet meer opgesteld. ${ }^{\text {II }}$ Ook de zogenoemde 'minikoningskwestie' in I990, toen koning Boudewijn weigerde de abortuswet te ondertekenen, heeft niet tot een reflectie over het hedendaagse koningschap geleid. Eerste minister Martens kondigde wel structurele maatregelen aan, maar die zijn er uiteindelijk nooit gekomen. ${ }^{\mathrm{I} 2}$ Anders dan in Nederland, ${ }^{13}$ is het in België ook nooit voorgekomen dat de eerste minister in een notitie aan de Kamer aangeeft van welke invulling van het koningschap de regering uitgaat. Ook de wetgever heeft zich nauwelijks over het koningschap gebogen. Al jaren wordt een wet verwacht om de dotaties aan de leden van de koninklijke familie te rationaliseren, maar ze is er vooralsnog niet. ${ }^{14}$ Als de monarchie in het parlement ter sprake komt, is het naar aanleiding van - echte of vermeende, ernstige of aangedikte - incidenten waarin de zonen van de Koning betrokken zijn. Een fundamenteel debat over de monarchie is er echter niet. Enkele Vlaamse politieke partijen hebben hun republikeinse overtuiging wel omgezet in voorstellen die uiteindelijk moeten leiden tot een afschaffing van de monarchie ${ }^{15}$ of een louter protocollaire monarchie. ${ }^{16}$ Een debat daarover is echter nooit gevoerd. Velen vinden dat 'het sop de kool niet waard' is. Uiteraard is de monarchie van een andere tijd. Ze is echter zo geëvolueerd, dat ze nog hooguit een schoonheidsvlekje op het blazoen van de democratie is. Ze heeft nog steeds een ruime aanhang bij de bevolking en dat levert ook een zekere democratische legitimatie op. Op institutioneel vlak heeft België trouwens wel andere katten te geselen. Weinigen hebben dus zin in een debat. Zeer recent is hier echter een verandering ingetreden. De huidige generatie politici lijkt het debat over de monarchie wel te willen aangaan. In maart 2010 pakten de kranten De Standaard en La Libre Belgique uit met een reeks interviews waaruit bleek dat een modernisering van de monarchie

II In het verleden werden wel vergelijkbare voorstellen gedaan vanuit republikeinse hoek. Ze werden niet in overweging genomen. Zie wetsvoorstel tot oprichting van een bijzondere commissie ermede belast een met redenen omkleed advies uit te brengen over de toepassing van de grondwettelijke beginselen betreffende de uitoefening van de prerogatieven van de Koning en over de verhoudingen der grote grondwettelijke machten onderling, Parl. St., Senaat, I996-97, I-607/I (Verreycken en Ceder); zie ook het voorstel van resolutie betreffende de oprichting van een commissie ter evaluatie van de koninklijke prerogatieven, Parl. St, Senaat, I999-2000, 2-500 (Van Quickenborne en De Decker).

I2 Zie hierover infra. nr. 83.

I3 Zie bv. brief van minister-president W. Kok aan de voorzitter van de Tweede Kamer der StatenGeneraal, I5 september 2000, Kamerstukken II I999/00, 27 409, nr. I en brief van minister-president M. Rutte aan de voorzitter van de Tweede Kamer der Staten-Generaal, 24 mei 20II, met de visie van het kabinet over het modern koningschap; 'Beschouwingen over het koningschap', https://zoek.officielebekendmakingen.nl/dossier/32372/kst-3279I-I.html.

I4 Zie infra nr. Ioo.

I5 Zie voorstel van verklaring tot herziening van de grondwet wat het afschaffen van de monarchie betreft, Parl. St., Kamer, 20I0-20II, Doc 53 Io6o/I (Vlaams Belang).

I6 Zie voorstel van verklaring tot herziening van de artikelen 36, 37, 40, 44, 45, 46, 72, 87, 88, 89, 9I, 93, 96, I02, I04, I05, I07, I08, I09, IIo, III, II2, II3, II4, I5I, I53, I6o, I65, I67, I97 en I98 van de grondwet, Parl. St., Kamer, 2005-2006, Doc 5I, 2300/00I (NV-A). 
geen taboe meer is. ${ }^{17}$ Ook tijdens de recente regeringsvorming stond het onderwerp op de agenda. ${ }^{18}$

-5. Het initiatief van de Vereniging voor de Vergelijkende Studie van het Recht van België en Nederland om over de rol van de Koning na te denken komt daarom op een goed moment. Een staatsvorm kan slechts gedijen als er een zekere consensus over bestaat. Verdwijnt die, doordat politieke partijen ze ter discussie stellen, dan mag men die discussie niet uit de weg gaan. Dat helpt niet. In 2002 verraste het congres van de Vlaamse liberalen vriend en vijand door zich uit te spreken voor de protocollaire monarchie. Kamervoorzitter en liberaal Herman Decroo relativeerde toen de stemming door te stellen dat die wellicht anders zou zijn uitgevallen indien er 'tien minder in de bar waren blijven hangen'. Ook premier Guy Verhofstadt verklaarde: 'Ik ben niet van plan te prutsen aan het koningschap. De Belgische monarchie is mee geëvolueerd met de moderne tijd. Waarover discussiëren we dan?'r9 'Ik zie niet in waarom er daarover discussie moet zijn en ik ben dan ook niet van plan ze te voeren. ${ }^{20}$ Vandaag, bijna tien jaar later, werpt VLD-voorzitter en zoon Alexander Decroo zich op tot pleitbezorger van de protocollaire monarchie. ${ }^{2 \mathrm{I}} \mathrm{Men}$ mag er niet op rekenen dat de storm wel zal overwaaien. Integendeel, men moet zien of er iets aan de hand is. Bovend'Eert schreef terecht: 'Het behoeft geen zinloze exercitie te zijn om het functioneren van het belangrijkste staatsorgaan op gezette tijden te toetsen aan de constitutionele uitgangspunten of rechtsbeginselen die bepalend zijn voor de inrichting van de staat. ${ }^{22}$ Wat is de actuele betekenis van het koningschap? Is er behoefte aan een hervorming van de monarchie? In dit preadvies gaan we in op de verschillende dimensies van de Koning: hij is staatshoofd (I), staat op het voorplan bij de vorming van de regering (II), oefent een aantal prerogatieven uit ten aanzien van het regeringsbeleid (III) en is ook een persoon van wie zelfs het privé- en gezinsleven een weerslag kan hebben op het publieke leven (IV). We gaan

'De macht van de kroon', De Standaard en La Libre Belgique, 20 maart 20Io. Zie ook S. Samyn en M. Buxant, Koning zonder land. De toekomst van de Belgische monarchie in woelige tijden, Amsterdam, De Bezige Bij, 20II, I9, p. I55-I69.

I8 In het verslag aan Koning Albert II, I7 oktober 20I0, van koninklijk verduidelijker De Wever, wordt in het hoofdstuk over 'Politieke vernieuwing' voorgesteld dat 'de Koninklijke functie wordt gemoderniseerd door de herziening van een aantal grondwetsartikelen.' Naar verluidt maakte De Wever uit zijn gesprekken op dat er consensus bestaat om de functie van de koning louter protocollair te maken. De krant De Morgen meldde: 'Het zou de bedoeling zijn om bij de start van de nieuwe regering met het Paleis onderhandelingen te starten over de modernisering van de functie. De wijziging van het grondwettelijk verankerde ambt kan pas tijdens de volgende regeerperiode gebeuren. Maar via de goedkeuring van een resolutie kan het nieuwe kader vorm krijgen. Dat zou bij de troonopvolging van Filip een feit moeten zijn. Want de Wetstraat gaat ervan uit dat Albert tijdens deze regeerperiode abdiceert.' 'Consensus over protocollaire functie van de Koning', De Morgen, 20 oktober 2010.

I9 'Verhofstadt weerstaat VLD-congres', 2 januari 2003.

20 'De Koning doet zijn werk uitstekend', Het Laatste Nieuws, 3I december 2002 en I januari 2003.

2I 'Het is tijd om de protocollaire invulling van de monarchie te betonneren. Zoals in Scandinavië.' S. Samyn en M. Buxant, Koning zonder land. De toekomst van de Belgische monarchie in woelige tijden, Amsterdam, De Bezige Bij, 20II, p. I6I-I62.

22 P.P.T. Bovend'Eert, 'Met of zonder Koning? de samenstelling van de regering in een moderne parlementaire democratie, in L. Prakke en A.J. Nieuwenhuis (eds.), Monarchie en Republiek, Zwolle, Tjeenk Willink, 200o, p. 2. 
na welke invulling de constitutionele beginselen over het koningschap in onze tijd krijgen met betrekking tot elk van deze dimensies. Welke ruimte laat de ministeriele verantwoordelijkheid voor de persoon binnen de instelling? Op welke wijze worden monarchie en democratie verzoend?

\section{De koning, het staatshoofd}

\section{Symbool van eenheid, stabiliteit, continuïteit en neutraliteit}

-6. De Koning is in de eerste plaats staatshoofd. Dat is zo vanzelfsprekend dat de grondwet het niet eens vermeldt, tenzij zijdelings in artikel 87, eerste lid, dat bepaalt dat de Koning niet tegelijk hoofd van een andere staat kan zijn zonder instemming van beide Kamers. ${ }^{23}$ Door te opteren voor een staatshoofd dat zijn ambt niet door een politieke strijd heeft verworven, maar door erfopvolging, van generatie op generatie, binnen eenzelfde familie, opteerde het Nationaal Congres voor stabiliteit, continuïteit en neutraliteit aan het hoofd van de staat. Terwijl er steeds weer andere meerderheden in het parlement zetelen en de regeringen komen en gaan, blijft de Koning een leven lang op de troon en zorgt de dynastie voor duurzaamheid in de tijd. De leden van het Nationaal Congres vreesden de ambities, intriges en politieke passies die de strijd om de macht in een republiek met zich brengt. ${ }^{24} \mathrm{De}$ republiek zaait verdeeldheid. Immers, zo wist Devaux: 'l'élection d'un président est le triomphe d'un parti sur un autre.'25 Van een koning wordt verwacht dat hij neutraal is en dat hij boven de partijen staat. Jan De Meyer schreef 'dat de monarchie een instelling is die niet bij het spel der partijen kan worden betrokken en die trouwens haar gezag en haar prestige moet verliezen indien zij, als monarchie, in dat spel betrokken wordt. ${ }^{26}$ De Koning moet dus steeds 'boven het strijdgewoel' blijven, hij moet een teken van verbondenheid zijn en de eenheid van de Staat en van de Natie

23 In het decreet van 22 november 1830 over de regeringsvorm wordt de koning wel uitdrukkelijk 'chef héréditaire' (erfelijk staatshoofd) genoemd. Tijdens de besprekingen in het Nationaal Congres was hij eveneens als zodanig aangeduid (zie bv. Liedts, Nothomb en Raikem, I9 november I830, E. Huyttens, I, p. IgI en v.) Daarenboven stemde het Nationaal Congres een decreet van 28 januari I83I 'sur le mode d'élection du chef de l'Etat' (Pasin. I830-I83I, p. I70) en een decreet van 2 juni I83I 'sur l'élection du chef de l'Etat' (Pasin. I830-I83I, p. 356) In het decreet van 4 juni I83I (Pasin, I830-I83I, p. 357) wordt Leopold I uiteindelijk Koning der Belgen genoemd, zonder dat de uitdrukking Staatshoofd nog wordt gebruikt. A. Van Welkenhuyzen, $\mathrm{V}^{\circ}$ Chef de l'état, R.P.D.B., I977, Compl. V, nr. I.

24 Zie Nothomb in E. Huyttens, I, p. I92: 'Il faut d'abord qu'il soit héréditaire, car la nécessité d'une élection occasionnerait un interrègne durant lequel la représentation nationale s'agitant sur elle-même serait aux prises avec toutes les passions. Pour faire en sorte que personne n'aspire à la première place, il faut la supposer à jamais occupée, et contraindre toutes les ambitions à se remuer dans une sphère secondaire.' Zie in die zin Leclercq, Zoude, Vilain XIIII, Lebeau, Wannaar en Destouvelles in E. Huyttens, I, p. I88, I90, I99, 209, 22I, 24I.

25 E. Huyttens, I, p. 2 I4 (20 november I830).

26 J. De Meyer, 'De monarchie tussen links en rechts in het hedendaagse Europa', Zes beschouwingen over de Monarchie, Atheneum Paperbacks, Polak \& Van Gennep, I966, p. 78-79. 
verpersoonlijken. ${ }^{27}$ In 1949 schreef de commissie-Soenens daarover: 'De grondwetgever heeft willen verhinderen dat de keuze van het staatshoofd, hoogste orgaan van de Natie, periodiek zou ter sprake komen (...) hij heeft gedacht dat onze koningen, duurzaam verbonden met de geschiedenis van de Natie, het levend symbool zouden worden van het Vaderland.' Dat laatste woord geeft aan dat we bij de emotionele en sociaal-psychologische aspecten van het koningschap zijn beland. Veelal hebben constitutionalisten er weinig aandacht voor. Ze voelen er zich zelfs wat onwennig bij. Die aspecten zijn ook moeilijk grijpbaar en hebben weinig staatsrechtelijke rele-

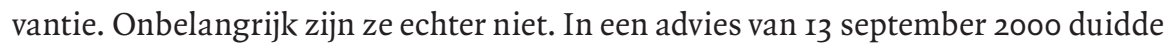
de Nederlandse Raad van State de symboolfunctie van de Koning als volgt: 'Een staatkundig en maatschappelijk bestel kan niet bestaan zonder noties van eenheid, van eigen identiteit en van staatkundig verleden. Het Nederlandse koningschap is in sterke mate de belichaming van die noties. ${ }^{28}$

-7. In het verdeelde België, waar een debat wordt gevoerd over de toekomst van het land, is die symbolische functie geenszins vanzelfsprekend. De monarchie kan een bindmiddel zijn, maar ook een teken van tegenspraak en een steen des aanstoots. Zoals André Molitor, van I96r tot I979 kabinetschefvan Boudewijn I, reeds aangaf, is de koninklijke functie 'symbolisch' in twee betekenissen van het woord: niet alleen vertegenwoordigt de koning de eenheid, maar zoals de ethymologie het aangeeft - sun-ballein, verenigen - poogt hij die eenheid ook tot stand te brengen. ${ }^{29}$ België is het project van de monarchie. Niet alleen straalt de Koning dat uit. Hij laat er ook in zijn toespraken niet de minste twijfel over bestaan. Net als zijn broer Boudewijn, ${ }^{30}$ laat ook Albert II niet na om de Belgen op te roepen hun eenheid te bewaren. Weliswaar zagen de koningen in dat de evolutie naar een federale staat onomkeerbaar is en dat zij daaraan ook hun loyale medewerking dienden te verlenen. Ze zijn echter beducht voor ontwikkelingen die ze als een risico voor het voortbestaan van de staat beschouwen. ${ }^{\text {I }}$ Onvermijdelijk worden ze daardoor tegenspelers van politici die het voortbestaan van de Belgische Staat geen meerwaarde vinden of die de autonomie van de deelstaten zo ver mogelijk willen doordrijven. We komen er later nog op terug.

27 L. de Lichtervelde, 'L'unité du Pouvoir', Bulletin de la Classe des lettres et des sciences morales et politiques de l'Académie Royale de Belgique, t. XXXVII, I95I, p. 508.

28 Raad van State, no. Wor.00.0347/I, I3 september 20I0, Kamerstukken II 2000/oI, 27400 III, A.

29 A. Molitor, La fonction royale en Belgique, Brussel, CRISP, $2^{\text {de }}$ uitgave, I994, p. 78.

30 Zo werd Vlaams minister-president L. Van den Brande op II januari rg93 in audiëntie ontvangen nadat hij, na de Sint Michielshervorming, meteen al pleitte voor een volgende stap in de staatshervorming. De Koning zette naar verluid zijn visie op de staatshervorming uiteen en waarschuwde tegen alles wat naar separatisme neigde. Eerste minister Dehaene nam de politieke verantwoordelijkheid hiervoor op zich. Zie Parl. Hand., Kamer, I992-I993, I8 januari I993, 744. Ze ook G. Polspoel en P. Van den Driessche, Koning en onderkoning. Over de invloed van het Hof en de macht van Jacques van Yperseele de Strihou, Van Halewyck, 20oI, p. I47.

3 I In zijn memoires publiceert gewezen eerste minister Martens een brief die koning Boudewijn schreef naar aanleiding van de staatshervorming van 1988 die volgends hem te ver ging. Zie W. Martens, De Mémoires, Lannoo, 2006, p. 823-825. 
-8. De koning symboliseert de eenheid van het staatsbestel en van de staatsmachten. Die zijn weliswaar gescheiden. In het staatshoofd komen ze echter - minstens op een symbolische wijze - weer samen. De Koning makkt deel uit van de federale wetgevende macht (art. $36 \mathrm{GW}$ ); hij bekrachtigt de wetten en kondigt ze af (art. Io9 GW). ${ }^{32}$ De federale uitvoerende macht berust bij de Koning (art. 37 GW) en de vonnissen en arresten van de rechterlijke macht worden 'in naam van de Koning' ten uitvoer gelegd (art. $40 \mathrm{GW}$ ). Alle personen bekleed met overheidsgezag - de ministers, de ambtenaren, diplomaten, magistraten en officieren ${ }^{33}$ - leggen een eed van getrouwheid aan de Koning af. ${ }^{34}$ Ook de deelentiteiten van het federale België zijn op een symbolische wijze met het staatshoofd verbonden. De aanwijzing van de voorzitters van de gemeenschaps- en gewestregeringen wordt immers bekrachtigd door de Koning in wiens handen zij de eed afleggen. ${ }^{35}$ Ook de ambtenaren van de Gemeenschappen en de Gewesten leggen die eed af. ${ }^{36}$ De Raad van State heeft de betekenis hiervan in een advies als volgt verduidelijkt: 'De eed van getrouwheid aan de Koning is, gelet op onze staatsstructuur, niet op te vatten als een erkenning van afhankelijkheid of onderdanigheid, doch enkel als een belofte van loyauteit tegenover de politieke gemeenschap waarvan de Koning de personificatie is. Hij is derhalve niet onverenigbaar met een door en binnen de Belgische staatsstructuur verleende autonomie. ${ }^{37}$

32 Daarbij wordt nog steeds de gepersonaliseerde formule gebruikt: 'Albert II, Koning der Belgen. Aan allen die nu zijn en hierna wezen zullen, Onzen Groet.' Art. 3, wet 3I mei I96I betreffende het gebruik der talen in wetgevingszaken, het opmaken, bekendmaken en inwerkingtreden van wetten en verordeningen, BS, 2I juni ig6r.

33 Alleen de parlementsleden zweren geen trouw aan de Koning.

34 Zie art. 2 decreet 22 juli I83I betreffende de eedaflegging bij de aanvang der grondwettelijke vertegenwoordigende monarchie, Bull. Off., nr. LXXVI.: 'Al de ambtenaren van de gerechtelijke en de administratieve orde, de officieren van de burgerwacht en van het leger en in het algemeen al de burgers belast met enig openbaar ambt of openbare dienst, moeten, alvorens in dienst te treden, de eed afleggen in de volgende bewoordingen: "Ik zweer getrouwheid aan de Koning, gehoorzaamheid aan de Grondwet en aan de wetten van het Belgische volk." Alleen de kamerleden en senatoren (art. I decreet 20 juli I83I) en de leden van de gemeenschaps- en gewestparlementen (...) zweren slechts "de Grondwet na te leven".'

35 Art. 6o, § 4, derde lid Bijzondere wet 8 augustus 1980 tot hervorming der instellingen, B.S., I5 augustus I980; art. 49, eerste lid, wet 3I december 1983 tot hervorming der instellingen voor de Duitstalige Gemeenschap, B.S., I8 januari I984; art. 35, § 3, eerste lid, Bijzondere wet 12 januari I989 met betrekking tot de Brusselse instellingen, B.S., I4 januari I989.

36 Zie artikel 87, §. 2, Bijzondere wet 8 augustus I980 tot hervorming der instellingen, B.S., I5 augustus I980. Zie evenwel de voorstellen om een eigen eedformule in te voeren, wetsvoorstel tot wijziging, wat betreft de eedformule voor personeelsleden die afhangen van de regeringen van de Gemeenschappen en de Gewesten, van het decreet van 20 juli I83I betreffende de eedaflegging bij de aanvang der grondwettelijke vertegenwoordigende monarchie, Parl. St., Kamer, 2010-20II, Doc. 53, o969/0oI (B. Weyts) en voorstel tot wijziging van de bijzondere wet van 8 augustus 1980 tot hervorming der instellingen met het oog op de overdracht van de bevoegdheid inzake het bepalen van de eedformule, Parl. St., Kamer, 20I0-20II, Doc. 53 0850/00I (A. Colen). Advies R.v.St., afd. Wetgeving, 9 december 1982 over een voorstel van decreet houdende bepaling van de eedformule af te leggen voor de Vlaamse Raad en voor de Vlaamse Gemeenschap en voorstel van decreet houdende eedaflegging van de leden van de Vlaamse Executieve. 
-9. Aan het staatshoofd, hij weze een koning of een president, worden steeds een aantal symbolische taken toegewezen. Hij vertegenwoordigt de Staat en de Natie in binnen- en buitenland. Hij legt staatsbezoeken af, ontvangt staatshoofden en regeringsleiders en neemt de geloofsbrieven in ontvangst van de diplomatieke vertegenwoordigers van andere staten. Hij gaat voor in een aantal nationale ceremonies en rituelen die het 'theater van de staat' uitmaken ${ }^{38}$ en geeft ook een persoonlijk gelaat aan de staatsinstellingen. Zijn portret wordt opgehangen in openbare gebouwen en scholen, het staat op postzegels en op munten. De koning is zo de verpersoonlijking van de Staat en van de Natie. In zijn boek The English Constitution onderstreepte Walter Bagehot het belang van die rol. Bagehot maakte een onderscheid tussen de 'effective' en de 'dignified parts of the Constitution'. Tot de eerste rekende hij de regering die effectief de macht uitoefent. Tot de tweede rekende hij de monarchie die nauwelijks macht heeft, maar daarom nog niet nutteloos is. Integendeel, ze heeft een fundamentele betekenis in het verzinnebeelden en versterken van de nationale eenheid en in het verzoenen van de burgers met hun instellingen. Het politieke kluwen van parlement, regering, politieke partijen, publieke opinie enz. gaat het petje van Jan-met-de-pet immers erg te boven, aldus Bagehot. Het koningschap daarentegen is wel begrijpelijk en boeiend bovendien. De monarchie zorgde voor een aura van warme affectieve legitimiteit waaraan de rationale en kille instellingen behoefte hebben. ${ }^{39}$ Voor Bagehot is de monarchie eigenlijk een scherm waarachter een republiek schuil gaat, waarvoor de bevolking echter nog niet rijp is. ${ }^{40}$ Bagehot schreef dit in 1867 , op een ogenblik dat de scholingsgraad nog zeer laag was. Of de beter opgeleide burger van vandaag nog steeds nood heeft aan de illusie dat de Koning het land regeert, mag men betwijfelen.

-Io. Doordat de Koning, over de jaren heen, een band met de bevolking heeft ontwikkeld, is hij in staat gevoelens van samenhorigheid en verbondenheid tot uiting te brengen, waaraan de gemeenschap nu en dan nood heeft. ${ }^{4 \mathrm{I}}$ Dat lijkt trouwens de core

$3^{8}$ Anders dan bv. het Verenigd Koninkrijk en Nederland, is België hierin nooit erg exuberant geweest. Alleen de Nationale feestdag (2I juli) en het Feest van de Dynastie (I5 november) hebben enige weerklank.

39 'The nature of a constitution, the action of an assembly, the play of parties, ... are complex factors, difficult to know and easy to mistake. But the action of a single will, the fact of a single mind, are easy ideas: anybody can make them out, and no one can ever forget them.' W. Bagehot, The English Constitution, Sussex Academic Press, I997, p. 2 I.

40 'To state the matter shortly, royalty is a government in which the attention of the nation is concentrated on one person doing interesting actions. A Republic is a government in which that attention is divided between many, who are all doing uninteresting actions. Accordingly, so long as human heart is strong and the human reason weak, royalty will be strong because it appeals to diffused feelings and Republics weak because they appeal to the understanding.' (p. 24) Zie D.M. Craig, 'Bagehot's republicanism', A. Olechonowicz (ed.), The Monarchy and the British Nation I780 tot the present, Cambridge, University Press, 2007, p. I39-I62.

4I Zie over het belang van een symbolische orde voor een politieke gemeenschap: D.W.J.M. Pessers, 'De symbolische legitimaties van de constitutionele monarchie', in D.J. Elzinga, De Nederlandse constitutionele monarchie in een veranderend Europa, Kluwer, Alpen aan de Rijn, 2006, p. 5I-6o (5I): 'Een politiek systeem als een staat omvat nu eenmaal ook een Gefühlsraum. Deze heeft niet zozeer betrekking op de juridische staatsordening, als wel op de natie waarvan de staat de juridische uitdrukking is. Naties worden gekenmerkt door een gemeenschappelijke taal en cultuur, door gemeenschappelijke herinneringen, door gemeenschappelijke trauma's of prestaties, 
business van de hedendaagse monarchie te zijn geworden. De koning en ook de leden van de koninklijke familie zijn zeer aanwezig in het land. Voortdurend leggen ze bezoeken af en nemen deel aan een breed scala aan activiteiten, zoals het uitreiken van onderscheidingen, het openen van tentoonstellingen en beurzen, het bezoeken van bedrijven, scholen en ziekenhuizen, het bijwonen van concerten en congressen, het huldigen van verdienstelijke landgenoten enz. Ook bij nationale rampen is het staatshoofd aanwezig en brengt het medeleven van het land tot uiting. Soms wordt er wel eens schamper over gedaan. Generaal De Gaulle bv. omschreef de taak van een niet-verkozen staatshoofd - koning of president - als het 'inhuldigen van de chrysanten' ('inaugurer les chrysanthèmes'). Het belang van deze symbolische orde, waarin rede en gevoel vermengd zijn, is nochtans niet te onderschatten. Dat moge blijken uit de talloze uitnodigingen, gericht tot de Koning of een lid van de koninklijke familie, waarmee het Paleis nog steeds wordt overspoeld en ook uit de commotie die ontstaat wanneer niet tijdig of niet gepast wordt gereageerd op een rampspoed die de bevolking treft. ${ }^{2}$ Wanneer het staatshoofd - hij weze koning of president - aanwezig is, deelt die namens de Natie, zo luidt het romantisch, in de vreugde en het verdriet, in de trots om geleverde prestaties en de treurnis om tegenslagen. Hij wordt dan katalysator van massagevoelens. Omdat hij niet verkozen is, maar door erfopvolging wordt aangeduid, is een koning misschien wel beter dan een president in staat om deze symbolische functie te vervullen. Hij is immers neutraal en staat boven de partijen. Hij wordt niet om de vier jaar vervangen en kan een continue band met het land aangaan Hij kan daardoor wellicht beter datgene wat de inwoners van een staat bindt, vertolken en versterken. Hedendaagse auteurs beklemtonen ook dat het koningschap in tijden van globalisering en europeanisering, in een samenleving die complexer en pluriformer wordt, een herkenningspunt kan zijn dat de nationale samenhang tot uiting brengt en bevordert. ${ }^{43}$

\section{De symbolische functie en de ministeriële verantwoordelijkheid}

-II. Ook de symbolische aspecten van het koningschap vallen onder de ministeriële verantwoordelijkheid. Het publieke optreden van het staatshoofd, de audiënties die hij verleent, de bezoeken die hij in binnen- en buitenland aflegt, de officiële reizen die hij maakt en de toespraken die hij houdt, dienen door de regering gedekt te zijn. Uit de staatsrechtelijke praktijk blijkt dat het keurslijf van de ministeriële

door een gemeenschappelijke trots op landschap, steden, cultuurgoederen, industrieën, ja zelfs de kwaliteit van het openbaar bestuur kan voorwerp van nationale trots zijn. Wie na een buitenlandse reis de Nederlandse grens passeert, rijdt niet de Nederlandse staat in, maar de Nederlandse Natie. Heimwee naar het vaderland betreft niet heimwee naar de staat, maar heimwee naar de natie ofwel, zoals de Duitsers zeggen, naar de Heimat: het vaderland waarin je je thuis voelt en waarin je je moedertaal spreekt.'

42 Dat ervoer het koningspaar toen zij in augustus I996, na de ontdekking van de lijken van de door Marc Dutroux ontvoerde meisjes, niet meteen uit hun vakantieoord Chateauneuf-de-Grasse naar het land terugkeerden om in de collectieve rouw en verontwaardiging te delen.

Zie bv. A. Joustra, 'Gered door Europa. De toekomst van de Nederlandse monarchie in de Europese Unie', in R. Meijer en H.J. Schoo (ed.), De Monarchie. Staatsrecht, volksgunst en het Huis van Oranje, Amsterdam, Prometheus, 2002, p. I69-I86. 
verantwoordelijkheid hier echter niet nodeloos strak wordt aangespannen. De Koning krijgt heel wat ruimte om zelf zijn publieke agenda te bepalen en ook om eigen accenten te leggen in de toespraken die hij houdt. Alleen over wat politiek controversieel zou kunnen zijn, heeft vooraf overleg plaats. Door de gevoeligheden, o.m. op communautair vlak, is het hier vaak spitsroeden lopen. Dat moge blijken uit enkele casussen over een audiëntie, een bezoek of een toespraak, die tot een activering van de ministeriële verantwoordelijkheid hebben geleid.

\section{A Audiënties en bezoeken}

-I2. Jaarlijks ontvangt de Koning honderden mensen in audiëntie en legt ook talloze bezoeken af. ${ }^{44}$ In het wekelijks overleg met de eerste minister komt de publieke agenda van de vorst aan bod. Alleen de belangrijkste activiteiten van de Koning worden echter doorgesproken. Niet over elke audiëntie die hij verleent of over elk bezoek dat hij aflegt, heeft er vooraf overleg plaats, laat staan dat de eerste minister er vooraf zijn goedkeuring aan verleent. Dat zou ook een haast onmogelijke zaak zijn. Vooral de bezoeken aan het buitenland krijgen aandacht. Ze hebben in het verleden in de Kamer al vaak tot een activering van de ministeriële verantwoordelijkheid geleid. 45 Voor de bezoeken in het binnenland beschikt de koning over veel meer ruimte voor een eigen invulling. Hier zal er slechts overleg met de eerste minister of een ander minister plaats vinden indien er mogelijk politieke gevolgen te duchten zijn. Dat was bijvoorbeeld het geval met de ontmoeting die koning Boudewijn op 22 mei 1979 had met de Voerense politicus José Happart die hem een petitie overhandigde. Deze in het licht van de taalkwestie zeer gevoelige ontmoeting was vooraf overlegd met de toenmalige minister van Binnenlandse Zaken. Daarover in de Kamer geïnterpelleerd, verklaarde eerste minister Martens dat de koning had gehandeld onder de verantwoordelijkheid van de minister van Binnenlandse Zaken die had 'geoordeeld dat het in de lijn van de traditie lag sommige burgers toe te laten, naar aanleiding van een koninklijk bezoek, petities aan het staatshoofd te overhandigen. ${ }^{{ }^{4} 6}$ Vaak wordt er echter geen overleg gepleegd. 'Er bestaat een vertrouwensrelatie waarbij wederzijds al eens wat risico's worden genomen', aldus gewezen eerste minister Dehaene. ${ }^{47}$ Soms ontstaat er politieke commotie terwijl men dat niet had verwacht. Zo bracht koning Albert II bijvoorbeeld op ro juli 1994 aan de vooravond van de Vlaamse feestdag een onaangekondigd bezoek aan Brugge waar hij de prijsuitreiking van de Guldensporen-marathon bijwoonde. Op een zonovergoten markt van Brugge werd

44 Zie het antwoord van de eerste minister op een antwoord over de 'officiële bezoeken van de leden van het koningshuis', Parl. Hand., Kamer 2008-2009, QRVA 52 038, 27 oktober 2008, p. 979I.

45 Zie bv. de interpellatie over het niet bijwonen door de Koning van de begrafenis van de Britse Koning George VI. Parl. Hand., Senaat, I95I-I952, I3 februari I952, p. 454. Zie ook het debat over de reis van het staatshoofd naar Kongo in juni 2007 en over het bezoek van het vorstenpaar, vergezeld door de eerste minister, aan het Vaticaan, naar aanleiding van de zaligverklaring van paus Johannes Paulus II. 'Wrevel in regering over zaligverklaring en pausbezoek', De Standaard, 26 april 201 .

46 Parl. Hand., Kamer, BZ I979, 23 mei i979, p. 43I-432.

47 L. Neuckermans en P. Van den Driessche, Albert Koning na Boudewijn, Leuven, Van Halewijck, I995, p. 53 . 
de 'Vlaamse Leeuw' - het officiële lied van de Vlaamse Gemeenschap - aangeheven. Inzoemende camera's registreerden dat de vorst zowaar enige regels van dat lied meelipte. Het bezoek leidde tot heel wat commotie in enkele Franstalige dagbladen en tot vragen van Franstalige parlementsleden die wel eens wilden weten welke excellentie de koninklijke zangstonde dekte. Eerste minister Dehaene nam de verantwoordelijkheid op zich en verdedigde ook Alberts optreden als een normale betuiging van eerbied voor de nieuwe instellingen..$^{8}$ Uiteindelijk koelde alles zonder blazen. Twee maanden later bezocht de vorst ook de Fêtes de Wallonie in Namen.

-I3. Ook inzake audiënties is de staatsrechtelijke praktijk in dezelfde zin gevestigd. De Koning ontvangt jaarlijks een groot aantal mensen in audiëntie: buitenlandse staatshoofden en regeringsleiders, politici uit binnen- en buitenland, diplomaten, militairen, academici, journalisten, verantwoordelijken uit de sociale en economische wereld, uit internationale organisaties en NGO's, mensen uit de artistieke, culturele en sportieve sector, uit het verenigingsleven, gewone burgers enz. Een gewezen kabinetsmedewerker van het Hof heeft het over 200 officiële audiënties die in een communiqué van het Paleis worden bekendgemaakt en daarnaast nog een groot aantal officieuze audiënties. ${ }^{49}$ In beginsel beslist de koning zelf vrij wie hij ontvangt. Hij zal de eerste minister wel vooraf verwittigen als er twijfels zouden kunnen rijzen over de opportuniteit van een audiëntie..$^{50}$ In de praktijk is er echter heel wat ruimte voor eigen initiatief. Zo heeft men er bv. geen bezwaar tegen dat de koning politici uit de oppositie en critici van het regeringsbeleid ontvangt. Hij heeft immers het recht zich op de hoogte te houden over wat er leeft in het land. Ook al leidt dat al eens tot fricties - in IgII viel er zelfs een regering over ${ }^{51}$ - in onze tijd zal de eerste minister zonder verpinken de verantwoordelijkheid op zich nemen, ook al laat hij soms niet na te preciseren dat hij vooraf niet was ingelicht laat staan dat zijn toestemming was gevraagd. Zo verleende koning Albert II op 3I januari 1996 een audiëntie aan Knack-journalist Chris De Stoop, die net een uitermate kritisch boek had gepubliceerd over het asielbeleid van minister van Binnenlandse zaken Johan Vande Lanotte, die dit boek als intellectueel oneerlijk had afgedaan. Daarover geïnterpelleerd in de Kamer zei eerste minister Dehaene 'dat alle daden van de Koning gedekt moeten zijn door een minister en dat het niet de gewoonte is dat audiënties vooraf worden voorgelegd of besproken. ${ }^{52}$ Op de vraag over een audiëntie die de

48 Parl. Hand., Kamer, I993-I994, PLEN I4 juli I994, 2I48-2I49. Zie ook L. Neuckermans en P. Van den Driessche, Albert Koning na Boudewijn, Leuven, Van Halewijck, I995, p. 53; L. Demullier, Twee Koningen vijf jaar na Boudewijn, Bijlage bij het Volk van ıo juli ı998.

49 Y. Monette, Métier de Roi de A à Z, Brussel, 2002, p. 22 (Audiences); zie ook A. Molitor, La fonction royale en Belgique, p. 50-52, 98-99.

50 Zie A. Molitor, La fonction royale en Belgique, p. I20.

5 I In I9II bood regeringsleider Schollaert zijn ontslag aan nadat Koning Albert I, te midden van een aankomende politieke crisis, een aantal ministers van staat, ook uit de oppositie, had ontvangen, en het Paleis een bericht hierover naar de pers had gelekt. Zie J. Velaers, Albert I. Koning in tijden van oorlog en crisis, Lannoo, 2009, p. I09-I26.

52 Parl. Hand., Kamer, I995-I996, I februari I996, II29-II30. Zie ook G. Polspoel en P. Van den Driessche, Koning en onderkoning. Over de invloed van het Hof en de macht van Jacques van Yperseele de Strihou, Van Halewyck, 20or. Zie ook het antwoord van eerste minister Verhofstadt aan Vlaams Blok-kamerlid Annemans, in verband met de audiëntie die koning Albert II aan bur- 
Koning had verleend aan journalist Hugo Gijssels, auteur van een kritisch boek over het Vlaams Blok, bevestigde de eerste minister dat een audiëntie had plaats gevonden en voegde eraan toe: 'Het is het voorrecht van de Vorst de mensen van Zijn keuze te ontvangen.' 53

-I4. Ook voor het publieke spreken en schrijven van de Koning geldt de ministeriele verantwoordelijkheid. Telkens hij, in het openbaar, het woord voert of een brief schrijft, ${ }^{54}$ moet hij gedekt zijn door een minister. Typisch voor de Belgische staatsrechtelijke praktijk is dat men er steeds naar gestreefd heeft om ook hier het keurslijf niet al te strak aan te spannen. In het verleden, vooral onder Leopold II (I865I909) en Albert I (I909-I934), zijn er zelfs gewoonten gegroeid, die de Koning wel erg veel ruimte boden. Weliswaar zijn die inmiddels weer uitgedoofd, maar - zoals hierna zal blijken - ze smeulen toch nog enigszins na.

-I5. Lange tijd bestond ook in ons land de gewoonte dat het staatshoofd bij de jaarlijkse opening van het parlement een troonrede uitsprak waarin het regeringsbeleid werd voorgesteld. ${ }^{55}$ In 1892 deden zich daarbij echter incidenten voor, die ook tegen de Koning gericht waren. Voor Leopold II hoefde het daarna niet meer. De poging van Albert I om in IgIo weer bij de traditie aan te knopen, leidde opnieuw tot incidenten. Ook hij was daarna niet langer bereid om zonder meer het regeringsbeleid uit te dragen en dan mee de kritiek te incasseren. Was dat trouwens niet strijdig met de koninklijke waardigheid? Over het voorlezen van de troonrede door de Britse koningin Elisabeth, stelde een BBC-commentator, weinig eerbiedig: 'Alles wat van de Koningin verwacht wordt, is dat ze voldoende sterke glazen heeft om de toespraak te kunnen voorlezen die de eerste minister heeft opgesteld. ${ }^{56}$ Leopold II wilde niet louter de spreekbuis van zijn regering zijn. Hij wilde overal te lande vrij kunnen spreken en zijn zorgen over de landsverdediging en het koloniaal beleid aan de bevolking kunnen kond doen, ook al zaten zijn ministers niet op dezelfde golflengte. Uit talloze aanvaringen ontstond uiteindelijk de typisch Belgische doctrine dat de Koning het recht heeft persoonlijke standpunten in te nemen die niet noodzakelijkerwijze door de regering worden gedeeld. Het beginsel van de minis-

gemeester Janssens van Antwerpen verleende: 'Het is de normale gang van zaken dat de Koning zonder enige politieke betekenis gezagdragers in ons land uitnodigt, hetzij op gemeentelijk, stedelijk, provinciaal of nationaal vlak. Ik begrijp uw diepe ontgoocheling: u zult nooit worden uitgenodigd en dat is ook normaal. U bent tegen de Koning, u bent tegen het koningschap, alleen weten uw kiezers dat nog altijd niet goed.' Parl. Hand., Kamer, 2006-2007, CRIV 5I Plen, I9 oktober 2008, 2.

53 Parl. Hand., Kamer, I998-I999, 30 november I998, BI53, P20819.

54 Zo schreef Koning Albert II onlangs, onder ministeriële verantwoordelijkheid, een brief aan VNsecretaris-generaal Ban Ki-Moon i.v.m. het mandaat van de VN-missie in Congo om op te treden tegen seksueel geweld.

55 Zie L. De Lichtervelde, 'Coutumes de la monarchie constitutionnelle', Académie royale de Belgique, Bulletin de la classe des lettres et des sciences morales et politiques, I948, t. XXXIV, p. 39-40.

56 J. Stengers, De koningen der Belgen, deel I, hfdst. I, I. p I67. 
teriële verantwoordelijkheid vergt immers niet, zo luidde het toen, dat de regering het eens is met WAT de Koning zegt, het volstaat dat zij het ermee eens is DAT hij het zegt. Deze doctrine - die soms de Schollaert-doctrine wordt genoemd, naar de gelijknamige regeringsleider die ze in het parlement verdedigde ${ }^{57}$ - heeft lange tijd ook in de rechtsleer aanhangers gehad..$^{8}$ Van meet af aan deed ze nochtans heel wat vragen rijzen. Werd zo het beginsel van de 'eenheid van de Kroon' niet geschonden? Vergde de ministeriële verantwoordelijkheid niet dat de standpunten van de Koning ook inhoudelijk door de ministers kunnen worden gedeeld en verdedigd?59 Na de Tweede Wereldoorlog werd de doctrine steeds vaker bekritiseerd. ${ }^{60}$ Thans lijkt ze te zijn verlaten. In april 1990 werd ze een laatste maal ingeroepen, bij de weigering van Koning Boudewijn om de abortuswet te ondertekenen. De brief van de koning aan de eerste minister, waarin hij zijn gewetensbezwaren uiteenzette, werd toen op verzoek van de koning en onder de verantwoordelijkheid van de regering, bekendgemaakt. Toen de oppositie in de Kamer opwierp dat de Kroon aldus werd ontbloot $^{6 \mathrm{I}}$ en dat de Koning zo in het politieke strijdgewoel terechtkwam, citeerde

57 Zie het antwoord van Schollaert op de interpellatie van de h. Furnemont over een publieke brief van Leopold II aan minister Schollaert i.v.m. de exploitatie van de kolonie. Ann. Parl., Kamer, 6 juli I909, p. I87I en v., I877. 'N'est-il pas naturel ... que le Roi ait des vues sur l'avenir du Congo et n'est -il pas légitimé qu'il désire en voir profiter le pays? Ces vues, je le répète, nous n'avons pas à en faire un programme, mais nous assumons entièrement la responsabilité du fait d'avoir donné au Roi l'occassion de les exprimer.' Zie eerder het debat naar aanleiding van een publieke brief van Leopold II aan minister van Oorlog Cousebant d'Alkemade in I904, waarin de Koning zich voor de persoonlijke dienstplicht uitsprak. Ann.Parl., Kamer, I904-I905, 6 december I904, p. 203. Zie J. Stengers, De koningen der Belgen, hfdst. I, II, p. 213 en 2I9 en C.H. Höjer, Le régime parlementaire belge de I9I8 à I940, p. 358; zie ook de analyse van M. Vauthier in Rev. Adm., I924, p. 53 en v. en Rev. Adm., I930, p. I97-206.

58 In 1908 schreef de gezaghebbende Orban: 'Tout en admettant que le roi, parlant en public ou écivant des lettres ou messages publics doit être couvert par la responsabilité ministérielle, il faut reconnaître que celle-ci n'implique pas l'impossibilité pour le ministère de laisser exprimer, parfois, par le Roi, des idées personnelles qu'il ne s'approprie pas, mais dont il admet parfaitement que le Roi puisse se déclarer partisan.' (O. Orban, Le droit constitutionnel de la Belgique, Liège-Paris, I908, t. II, p. 229) Louis de Lichtervelde schreef nog in I945: 'Il peut avec le consentement de ses Ministres qui portent tout au moins la responsabilité de l'opportunité de son intervention, développer des vues qui dépassent le programme du Cabinet.' (Préface in Métier du roi, p. Io). Jan Meyer schreef in I96r: 'On pourrait dire plus exactement que dans des cas de ce genre, il est possible que le gouvernement prenne la responsabilité de laisser le Roi traduire des idées dont le gouvernement n'entend pas lui-même assumer la responsabilité.' (J. De Meyer, 'Réflexions sur la monarchie parlementaire', Res Publica, I961, p. 243-250).

59 Rev. Adm., I9Io, II; F. Delpérée en B. Dupret, 'Nul ne peut découvrir la couronne', Les cahiers constitutionelles, p. 20.

6o Volgens Devisscher bestaat er geen enkele reden inzake ministeriële verantwoordelijkheid een onderscheid te maken tussen de inhoud en de opportuniteit van de bekendmaking (P. De Visscher, 'La Fonction royale', p. 682). W.J. Ganshof van der Meersch schreef over de Schollaert-doctrine: 'Cette règle est, au surplus, dangereuse. Même en n'en usant qu'avec mesure et prudence, l'expérience révèle que la pratique expose le Roi à être discuté et donc diminué dans son autorité.', in W.J. Ganshof van der Meersch, 'Le Commandement de l'armée et la responsabilité ministérielle en droit constitutionnel belge', p. 279.

6I Zie ook in die zin R. Lallemand, 'La conscience royale et la représentation de la Nation', J.T., I990, p. 466. R. Ergec, 'L'institution monarchique à l'épreuve de la crise', JT, I99o, p. 266. B. Dupret, 'La Couronne a-t-elle été découverte?’, p. I2: ‘Dans la crise du début avril, la Couronne a été découverte pour des raisons précises. ... Au-delà de toute unité de façade, la division de l'exécutif s'est étalée sur la place publique. Si la lettre de la règle constitutionnele qui veut que 'nulle peut découvrir la Couronne' a été préservée, son esprit a été méconnu.' 
eerste minister Wilfried Martens letterlijk de verklaring van Schollaert uit 1909. ${ }^{62}$ Dat waren echter uitzonderlijke omstandigheden. We komen er later nog op terug. Dat de Koning in een toespraak, onder ministeriële verantwoordelijkheid, ingaat tegen het regeringsbeleid zou thans niet meer worden aanvaard. ${ }^{63}$

-I6. Onder Albert I ontstond een andere praktijk. Het was de beginperiode van de coalitieregeringen. Ze hadden het moeilijk om compromissen te sluiten en die aan het parlement en aan de publieke opinie verkocht te krijgen. Albert had tijdens de Eerste Wereldoorlog een enorm prestige verworven. Zijn populariteit was ongeëvenaard. Het verwondert dan ook niet dat de regeringen poogden er hun voordeel mee te doen. Er ontstond een nieuw fenomeen. Om de regering te steunen, schreef de koning een brief aan de eerste minister of aan een minister. ${ }^{64}$ Die brief werd meteen in de pers gepubliceerd. In die brief feliciteerde de vorst zijn regering, met een verdrag dat was onderhandeld, een wetsontwerp dat was ingediend, een amendement dat werd voorgesteld en een enkele keer suggereerde hij zelf een oplossing voor een beleidsprobleem. Onder Leopold III kreeg dit een vervolg met de bekendmaking van een toespraak van de Koning in de ministerraad in 1936 waarin hij een wending in het buitenlands beleid verdedigde. ${ }^{65}$ Die publiek gemaakte brieven en toespraken waren een uiting van de sterkte van de koning, maar ook van de zwakte van de regering: de ministers hadden het gezag van het staatshoofd nodig om hun beleid te dekken. De constitutionele rollen werden als het ware omgekeerd. Niet de ministers dekten de koning, maar de koning dekte zijn ministers. In 1949 waarschuwde de commissie-Soenens dat de regering er zich vooral moet 'voor wachten aan de Koning de raad te geven een betwistbare maatregel publiek goed te keuren; de grondwettelijke regel zou inderdaad omgekeerd worden indien men de ministers door de Koning liet dekken. ${ }^{66}$ Ook deze praktijken lijken thans te zijn uitgedoofd. In een milde vorm flakkeren ze soms toch weer op. Zowel koning Boudewijn ${ }^{67}$ als

62 Parl. Hand, Senaat, I989-I99o, I9 april I99o, I909.

63 Molitor schreef in I98I dat het de Koning niet veroorloofd is in het openbaar stelling te nemen 'door persoonlijke interpretaties die in tegenspraak zouden zijn met de beslissingen van het wettelijk land.' A. Molitor, 'Bedenkingen bij de koninklijke taak', in Wij, Koning der Belgen. 150 jaar Grondwettelijke Monarchie, Brussel, r98I, p. I8. Hij wees er terecht op dat de regel van de ministeriële verantwoordelijkheid ertoe strekt 'de vorst en de continuïteit van de dynastie (te) behoeden tegen de risico's die zij zouden lopen bij het innemen van persoonlijke en openbare standpunten, op bepaalde momenten in onze geschiedenis; dit kan in een pluralistisch land aanleiding geven tot felle debatten, bij voorbeeld de schoolkwestie of de abortuswetgeving.' (I6).

64 Zo zijn er publieke brieven van Albert over tal van zwaarwichtige naoorlogse kwesties: het Verdrag van Versailles, I919, de invoering van de achturenwerkdag, I92I, de verlenging van de dienstplicht, 1923, het herstelbeleid, 1926 en de internationale economische ordening, I932, en - last but not least - het amnestievraagstuk (I934).

65 Zie J. Velaers en H. Van Goethem, Leopold III. De Koning, het land, de oorlog, Lannoo, I994, p. $58-63$.

66 Zie ook A. Van Welkenhuyzen, $V^{\circ}$ Chef de l'état, R.P.D.B., I977, Compl. V.

67 Op 20 december 1979 hield de koning in het openbaar een lofrede op de regering-Martens I die nauwelijks acht maanden in functie was. De vorst zei: 'Sinds uw ambtsaanvaarding aan het hoofd van de regering hebt u zovele blijken gegeven, niet allen van begrip en verzoeningsgezindheid, maar ook van vastberadenheid en zin voor verantwoordelijkheid.' V. Nees (red.) Wij, Boudewijn, Koning der Belgen, Het politiek, sociaal en moreel testament van een nobel vorst, Uitgeverij Editions, 1996, p. 966. 
koning Albert $\mathrm{II}^{68}$ heeft in het verleden reeds openlijk de eerste minister en de regering geloofd voor het gevoerde beleid. Hoe moeten we die loftuitingen interpreteren in het licht van de ministeriële verantwoordelijkheid? Men mag hopen dat ze niet door de eerste minister zelf zijn geïnspireerd. Wellicht is de Koning oprecht tevreden over zijn premier en wil hij dat ook laten weten. Soms gaat het ook om beleid dat op Europees vlak op grote waardering is onthaald. Toch begeeft de Koning zich dan op een politiek pad, dat voor een neutraal staatshoofd taboe zou moeten zijn. De eerste minister, die gisteren misschien nog door de oppositie scherp werd gehekeld, blijkt vandaag een medestander van formaat te hebben: de Koning zelf. Dergelijke toespraken hebben in het verleden tot scherpe kritiek geleid vanwege de oppositie. Wie zich in het politiek strijdgewoel begeeft, mag politieke kritiek verwachten. ${ }^{69}$

-I7. Veelal zijn de toespraken van de Belgische koningen de persoonlijke boodschappen die zij tot de Natie willen richten. De Koning voert vaak het woord. Bij zijn eedaflegging voor de Verenigde Kamers spreekt hij een troonrede uit. Jaarlijks houdt hij in het Paleis een nieuwjaarstoespraak tot de overheden van het land. Ook bij staatsbezoeken en ontvangsten in binnen- en buitenland, herdenkingen, verjaardagen of gelegenheden allerhande, neemt de Koning het woord. Ten slotte is er de traditie van de tv-toespraken op $2 \mathrm{I}$ juli, naar aanleiding van de nationale feestdag, en op 24 december, op kerstavond. Al die toespraken worden onder ministeriële verantwoordelijkheid uitgesproken. Zij dragen echter duidelijk de stempel van de Koning. Dat blijkt zowel uit de wijze waarop ze tot stand komen, als uit de toon en de inhoud ervan. ${ }^{70}$ In samenwerking met zijn kabinet stelt de Koning het ontwerp op. Dat wordt voor fiat aan de eerste minister of de bevoegde vakminister overgemaakt. ${ }^{71}$

68 Zo zong Albert II in zijn nieuwjaarstoespraak van 2002 de lof van het Europese voorzitterschap van de regering-Verhofstadt en pleitte hij voor communautaire vrede, wat toen tot scherpe kritiek van CD\&V-voorzitter Stefaan De Clerck leidde die zei 'Verhofstadt mag de Koning niet misbruiken voor zijn politieke strategieën'. Zie De Morgen, 22 juli 2002. In zijn kersttoespraak van 2010 zong de Koning opnieuw de lof van het Europese voorzitterschap, ditmaal van de regeringLeterme II.

69 K. Rimanque en M. Wouters schreven terecht: 'De grondwet vereist dat de ministers de verantwoordelijkheid opnemen voor de handelingen van de koning en niet omgekeerd. Schending van deze absolute verplichting tot discretie zou er toe kunnen leiden dat de Koning ertoe wordt aangespoord zijn prestige bij de bevolking aan te wenden als pleitbezorger van de politiek van de regeringsmeerderheid. Op deze wijze zou het vertrouwen in zijn onpartijdigheid ernstig op de proef worden gesteld.' K. Rimanque en M. Wouters, 'Het optreden van de koning in België, in het bijzonder tijdens regeringscrisissen', Res Publica, I99I/I, p. Io6. Zie ook P. De Vissscher, 'La Fonction royale', p. 702 ; W.J. Ganshof van der Meersch, 'Des rapports entre le chef de l'Etat et le gouvernements e n droit constitutionnel belge', p. I92; A. Van Welkenhuyzen, $V^{\circ}$ Chef de l'Etat, R.P.D.B., I977, Compl. V, nr. 55 .

70 Zie A. Molitor, La fonction royale en Belgique, p I02: '(...) le texte arrêté par le Roi est soumis à l'approbation du ministre compétent par les soins du Cabinet du Roi. Le ministre suggère des amendements de fond ou de forme. Le texte définitif est fixé de commun accord. Cette conception paraît conforme aux particularités du statut constitutionnel de la monarchie en Belgique. Le Roi agit toujours sous la responsabilité de ses ministres. Mais il a dans certains cas et toujours sous leur responsabilité un mode d'action personnel. Il lui incombe de garder les intérêts permanents de la Nation et il peut - et doit - rappeler ceux-ci lorsqu'il l'estime nécessaire ou opportun.'

7I C. Koninckx, Le Roi en Belgique, Tout savoir sur, Brussel, 2000, Kluwer, p. II7. 
Wanneer de regering het niet helemaal eens is met de tekst, zal zij wijzigingen voorstellen. ${ }^{72} \mathrm{Zij}$ is immers verantwoordelijk..$^{73}$ Dit wordt ook steevast als reden aangevoerd voor de weigering van het staatshoofd om een interview te geven voor radio of televisie. ${ }^{74}$ De dekking door de regering vergt immers voorafgaand overleg over de uitspraken die de koning zal doen. Dat impliceert weliswaar niet dat hij slechts de woordvoerder is van de regering. Als de Koning spreekt, is hij zelf aan het woord.75

-I8. Dat de typisch Belgische benadering over het spreken en schrijven van de Koning ook in onze tijd nog uitlopers kent, tonen de gebeurtenissen aan van de zomer van I996 toen er een golf van verontwaardiging over het land ging na het vinden van de lijkjes van de slachtoffers van Marc Dutroux. De Koning ontpopte zich toen tot vertolker van het massale ongenoegen van de bevolking over de falende politie en justitie. Nadat het vorstenpaar de ouders van de vermoorde meisjes had ontvangen, maakte het Paleis op ro september 1996 een communiqué bekend waaruit bleek dat de Koning de minister van Justitie Stefaan De Clerck ter verantwoording riep. Hij eiste volledige klaarheid in de zaak Dutroux en makte een lijst met desiderata in verband met politie en justitie over. De omstandigheden waarin dit gebeurde zijn nog steeds niet helemaal opgehelderd. ${ }^{7}$ Het heeft er echter alle schijn van dat de minister van Justitie vooraf over dit communiqué niet was ingelicht. Het Kabinet van de premier haastte zich wel nadien te stellen dat de mededeling van het Paleis door de hele regering werd gedekt. ${ }^{77}$ De minister van Justitie deed trouwens zijn voordeel met het koninklijk initiatief. Een aantal van de maatregelen waar de koning publiek op aandrong en die ook de minister wilde nemen - zoals bv. een vorm van externe controle op de rechterlijke macht - waren op dat ogenblik immers betwist. In de oppositie klonk echter kritiek. De liberale leider Louis Michel verklaarde: 'Dit debat hoort in het parlement thuis. Men kan het zwaartepunt van de democratie niet verplaatsen. ${ }^{78}$ Historicus en kenner van de monarchie M. Van den Wijngaert commentarieerde later dat 'de koning de indruk gaf aan de kant van het volk te staan. Politiek gezien was dat gevaarlijk omdat de mensen de regering als de schuldige zagen. Terwijl die regering natuurlijk ook een beter gerecht en een betere politie wilde. Ik twijfel niet aan de oprechtheid van Albert, maar grondwettelijk kon hij

72 F. Delpérée, 'Le Roi règne et ne gouverne pas', J.T., I990, p. 702; L. De Lichtervelde, 'Coutumes de la Monarchie constitutionnelle', Académie royale de Belgique, Bulletin de la classe des lettres et des sciences morales et politiques, I948, t. XXXIV, p. I6I.

73 L. De Lichtervelde, 'Préface', in Métier de Roi. Léopold I, Léopold II, Albert I, Léopold III, Brussel, I945, 9; Molitor, La fonction royale en Belgique, I979, I02; G. De Coninck, Koning der Belgen: Eender en Anders, Gent, Mys en Breesch, I99I, p. I3.

74 Y. Monette, Métier de Roi de A à Z, p. I29 (Neutralité).

75 F. Delpérée, 'Le Roi règne et ne gouverne pas', J.T., I990, 702.

76 Ons relaas is gebaseerd op G. Polspoel en P. Van den Driessche, Koning en onderkoning. Over de invloed van het Hof en de macht van Jacques van Yperseele de Strihou, Van Halewyck, 20oI, II9I20 en L. Demulier, Twee Koningen vijf jaar na Boudewijn, Bijlage bij het Volk van ro juli I998.

77 Minister De Clerck verklaarde tien jaar later: 'C'est une communication qui a suscité des réactions aussi au sein du gouvernement. Mais il a couvert le roi sans aucun problème. Le Roi avait très bien analysé la situation; cela a été accepté par les responsables politiques. C'était un peu exceptionnel, mais la situation était exceptionnel. Le pays était très secoué. Il était adéquat que le Roi intervienne d'une manière forte.' La Libre Belgique, 22 juli 2006.

De Volkskrant, I2 september 1996. 
de minister van Justitie niet publiek ter verantwoording roepen.'79 Het gebeuren kreeg trouwens nog een vervolg. Enkele dagen later, op I8 oktober 1996, werd in het Paleis een rondetafelconferentie georganiseerd waaraan de ouders van de slachtoffers, deskundigen en beleidsmensen deelnamen. De Koning, ditmaal geflankeerd door de minister van Justitie, sprak er opnieuw strenge taal aan het adres van de magistratuur, de politie en de overheid. Dat twee dagen later, op 20 oktober 1996, driehonderdduizend mensen vreedzaam, in een Witte Mars, door de straten van de hoofdstad trokken, werd mede aan het ongebruikelijke initiatief van de Koning geweten, die zoals een minister het treffend formuleerde, door zijn ongebruikelijke initiatieven, als een bliksemafleider de te grote emotionaliteit van de bevolking wist te ontladen. Wellicht toont Alberts optreden, in die voor het land zo traumatische periode, inderdaad aan dat het spreken van het staatshoofd soms een helend effect kan hebben. ${ }^{80}$

-I9. Veelal zijn de toespraken van de koning niet zo controversieel. ${ }^{8 \mathrm{r}} \mathrm{Hij}$ gaat zelden in op actuele beleidskwesties. Hij beoefent veeleer het langetermijndenken en heeft het over normen en waarden en over de uitdagingen voor de samenleving: ${ }^{82}$ thema's die de Koning nauw aan het hart liggen en waarover vaak een ruime consensus bestaat. Dat is zeer terecht. In de constitutionele monarchie van de eenentwintigste eeuw mag men van het staatshoofd immers verwachten dat hij politiek neutraal is en boven de partijen staat. Slechts binnen de beslotenheid van het Kroonberaad spreekt de koning 'vrij'. Hij heeft het recht te pogen invloed uit te oefenen, doch dan alleen in de samenspraak met zijn ministers, niet in zijn toespraken tot de Natie. De regering die het ermee eens is dat de Koning met zijn persoonlijke opvattingen aan het politiek debat deelneemt, bewijst de monarchie uiteindelijk geen dienst. Door publiek stelling te nemen over actuele problemen waarover de samenleving verdeeld is, kan hij zelf voorwerp van politieke controverse worden. Monette stelt dan ook terecht: 'Tout l'art consiste dès lors à conjuguer analyse pertinente et neutralité ou, en d'autres termes, à éviter tant la prise de position trop politique que les généralités sans intérêt. ${ }^{83}$ Een moeilijke evenwichtsoefening. Van zodra de woorden van de Koning de diepgang van de leuze 'melk is goed voor elk' overstijgen, kunnen ze tot controverse leiden. Als de vorst bv. waarschuwt tegen racisme en onverdraagzaamheid heeft dat steevast zure oprispingen van extreemrechtse partijen tot gevolg. Honni soit qui mal y pense. Tegenwind komt er ook als hij zich uitlaat over

79 M. Van den Wijngaert, Knack, 3I oktober 200I, p. 40. Zie ook over de kritische reacties P. Vaute, Voie royale, Essai sur le modèle belge de la monarchie, Brussel, Ed. Nous, I998, p. I32-I33.

8o Vergelijk met de oproep van GroenLinks politica Femke Halsema die na de moord op Theo Van Gogh de koningin opriep een troostend woord te spreken.

8I P. Boucquey, 'Les messages du Roi', Rev. B. dr. Const. , I997, p. 3-22.

82 Molitor stelt: 'Il lui incombe de garder les intérêts permanents de la Nation et il peut - et doit - rappeler ceux-ci lorsqu'il l'estime nécessaire ou opportun.'A. Molitor, La fonction royale en Belgique, p. I02.

83 P.Y. Monette, Métier de Roi de A à Z, p. 54 (Discours royaux). 
een beleidsdomein, bv. het talenonderwijs,${ }^{84}$ dat tot de bevoegdheid van de gemeenschappen of de gewesten behoort en waarvoor de federale overheid geen beleid kan voeren. ${ }^{85}$

-20. In een verdeelde staat als België, is de 'eenheid van het land' een politiek thema bij uitstek. Dat mocht koning Albert ervaren toen hij in januari 2006 in zijn toespraak tot de overheden van het land de spanningen tussen de gewesten ter sprake bracht en aangaf dat het antwoord daarop 'niet bestaat in een in zichzelf keren van elk gewest, ook niet in het ontwikkelen van een subnationalisme, en evenmin in openlijk of omfloerst separatisme'. ${ }^{86}$ De toespraak was gedekt door de federale premier Verhofstadt. De Vlaamse minister-president Leterme kon ze maar matig waarderen. Nog in het Paleis sprak hij de koning erover aan en drukte hem de noodzaak van een diepgaande staatshervorming op het hart. Later maakte hij in een broeierig Vlaams Parlement duidelijk dat de Koning het beleid van de Vlaamse regering niet kon beïnvloeden. ${ }^{87}$ Ook de kroonprins liet al verstaan dat wie aan België raakt, met hem te doen zou krijgen. ${ }^{88}$ Daarover ondervraagd in de Kamer, verklaarde diezelfde premier Verhofstadt toen 'dat hij zich kan voorstellen dat de prins zich afzet tegen partijen die de splitsing van het land voorstaan, maar dat dit evenwel niet in overeenstemming is met de huidige en vooral de toekomstige rol van de prins in ons land.' De eerste minister waarschuwde er nog voor dat als de leden van de koninklijke familie zelf het voorwerp worden van een politieke controverse 'dit afstraalt op de monarchie zelf en op het staatshoofd in het bijzonder wiens politieke neutraliteit natuurlijk onbetwistbaar moet zijn. ${ }^{89}$ Daarmee is een niet geringe paradox voor de Belgische monarchie blootgelegd. Het staatshoofd wordt geacht de eenheid van het

84 In zijn nieuwjaarstoespraak van 1996 pleitte de koning voor het aanleren van de tweede taal vanaf de tweede kleuterklas.

85 Minister-president L. Van den Brande stelde in het Vlaamse Parlement dat de federale regering zich terughoudend moet opstellen wanneer zij de koning wil dekken in materies die tot de Vlaamse bevoegdheid horen. Hij nuanceerde dit echter meteen zelf door te stellen: 'Men mag echter evenmin in het andere uiterste vallen. Als er immers over bevoegdheden die ons nu exclusief toekomen, nooit één overweging kan gemaakt worden, dan raken we zelf in moeilijkheden als het gaat om bevoegdheden die niet de onze zijn.' Hand., Vl. Raad, 7 februari I996, p. I325.

86 Het gehele citaat luidt als volgt: 'De tweede kwestie die ik met U wou bespreken, betreft de spanningen tussen gewesten. Ze bestaan in talrijke Europese landen en ook wij ontsnappen er niet aan zoals $U$ wel weet. In vele gevallen worden ze nog geaccentueerd door de verspreiding van twee vaststellingen. Enerzijds het bestaan van een verschil in welstand en anderzijds een verschil in beleid. Die ongelijke toestand, die met zich geldoverdrachten tussen gewesten meebrengt, doet zich voor in vele Europese landen. In die omstandigheden bestaat het antwoord niet in een in zichzelf keren van elk gewest, ook niet in het ontwikkelen van een subnationalisme, en evenmin in openlijk of omfloerst separatisme. Breuken en scheidingen vallen meestal duur uit voor alle betrokkenen of ze nu rijk of weinig welvarend zijn. Ook de menselijke kostprijs mag zeker niet vergeten worden; hem geringschatten zou een grove fout zijn. Op al die vlakken mag men geen illusies koesteren.'

87 Zie Hand. Vl. Parl., 2005-2006, I februari 2006.

88 De verklaring luidde: 'Sommige mensen en partijen, zoals het Vlaams Belang, zijn tegen België en willen ons land kapotmaken. Ik kan u verzekeren dat ze dan met mij te maken krijgen.'

89 Antwoord van eerste minister Verhofstadt over de samengevoegde vragen van de hh. Annemans en Cocriamont over 'de uitspraken van kroonprins Filip'. Parl. Hand.; Kamer, 2004-2005, CRIV 5I PLEN o96, 2 december 2004, p. 4. Zie over de ministeriële verantwoordelijkheid voor de leden van de Koninklijke familie, infra. 
land te belichamen. Zodra hij die eenheid echter al te zeer benadrukt, dreigt hij een teken van tegenspraak te worden. Omdat de neutraliteit de belangrijkste troef is van de Koning om de staat te symboliseren en het staatshoofd van allen te zijn, is neutraliteit zeker ten aanzien van de politieke aspecten van de hervorming van de staat ten zeerste geboden.

\section{De koning, een institutionele moderator}

-2I. Precies omdat een door erfopvolging aangeduid staatshoofd neutraal is en boven de politieke partijen staat, is hij geschikt om na verkiezingen of na een politieke crisis ervoor te zorgen dat de trein van het parlementair systeem weer op de rails geraakt. Dat is althans de insteek van de grondwet. Het Nationaal Congres was hier schatplichtig aan de ideeën van Benjamin Constant. Die zag in de Koning een 'pouvoir neutre et intermédiaire' of ook wel een 'pouvoir régulateur' of een 'pouvoir modérateur', ${ }^{\circ}$ die vooral in actie komt als het politiek proces hapert of opnieuw op gang moet worden gebracht..$^{91}$ Hij beschikt dan over instrumenten om de instellingen weer uit het slop te halen. Hij benoemt en ontslaat de ministers en staatssecretarissen (art. 96, eerste lid en I04 GW) en kan, onder strikte voorwaarden, de Kamer van Volksvertegenwoordigers ontbinden, wat meteen ook de ontbinding van de Senaat tot gevolg heeft (art. $46 \mathrm{GW}$ ). Die bevoegdheden komen hem toe als staatshoofd..$^{2}$

\section{I}

De vorming van de regering

-22. De vorming van de regering is ongetwijfeld de belangrijkste politieke rol die de Koning heeft te vervullen. Eigenlijk bepaalt de grondwet slechts dat de Koning de ministers benoemt. Hij dient dus minstens het benoemingsbesluit te tekenen. Al bij de eerste regeringsvorming door Leopold I in I83I ontstond de gewoonte dat de Koning een formateur aanstelt die hij belast met de vorming van de regering. ${ }^{93}$ Ook nadat de reële Government making power naar het parlement en de politieke partijen overging, bleef de Koning zijn rol spelen. Hij initieert, faciliteert en begeleidt het proces door telkens weer initiatieven te nemen die tot de vorming van de regering kunnen bijdragen. Strikte regels zijn er nauwelijks. ${ }^{94}$ Alleen het doel ligt vast: zo vlug mogelijk een duurzame regering vormen die door een meerderheid in de

90 'Le pouvoir qui se maintient par l'hérédité et l'inviolabilité n'est qu'un pouvoir modérateur', verklaarde Nothomb in het Nationaal Congres. E. Huyttens, t. I, I9 november I830, p. I93.

9I Zie hierover D.J. Elzinga, 'Monarchie en constitutioneel neutrum. Over de betekenis van de "pouvoir neutre" in de Nederlandse democratie', in D.J. Elzinga, De Nederlandse constitutionele monarchie in een veranderend Europa, Kluwer, Alpen aan de Rijn, 2006, p. 7.

W.J. Ganshof van der Meersch, 'Des rapports entre le chef de l'Etat et le gouvernement en droit constitutionnel belge', Rev. dr. Int. dr. comp., nr. spec., I950, p. I83.

93 J. Stengers, 'Leopold Ier et la formation de la Coutume constitutionnelle en Belgique', in Liber Amicorum J. Gilissen, Antwerpen, Kluwer rechtswetenschappen, 1983, p. 328-329.

$94 \mathrm{~K}$. Rimanque en M. Wouters, 'Het optreden van de koning in België, in het bijzonder tijdens regeringscrisissen', Res Publica, I99I/I, p. II9-I20. 
Kamer wordt gesteund of minstens gedoogd. Het is het prerogatief van de Koning om de middelen te kiezen om dat doel te bereiken. We zullen hierna zijn taak als procesbegeleider van de regeringsvorming belichten. C.M.J. Schuyt schreef over de Nederlandse monarchie: 'In het politieke proces presenteert de koning zich op een wijze die neutraliteit suggereert: hij verschijnt als iemand die boven de partijen staat. En juist omdat hij niet op uitgesproken en zichtbare wijze direct aan het politieke spel deel heeft, brengt hij wellicht een element in waardoor het spel mogelijk is. ${ }^{95}$ De hamvraag is echter of de Koning door de regeringsvorming niet onvermijdelijk in het politieke spel terechtkomt.

-23. De voorbije periode was dat in België zeker het geval. Ook in het verleden verliep een regeringsvorming al wel eens moeizaam. In de naoorlogse jaren zijn er twee periodes die door grote regeringsinstabiliteit worden gekenmerkt: tijdens de Koningskwestie, tussen I2 februari I945 en I6 augustus I950, diende de Regent zeven regeringen te vormen en in de periode die de tweede staatshervorming voorafging, tussen 20 oktober 1978 en 2I september I98I, vormde Koning Boudewijn vijf regeringen, waarvan enkele ook in zeer moeizame omstandigheden. Vaak lopen regeringsvormingen echter ook 'van een leien dakje'. Ook Koning Albert II stuitte in zijn eerste jaren niet op onoverkomelijke problemen. Vanaf 2007 lijkt het devies van de Belgische staat echter veranderd van 'L'Union fait la force, 'Eendracht maakt macht' in 'Rien ne va plus'. Al na de verkiezingen van ro juni 2007 duurde het I94 dagen vooraleer de tijdelijke regering-Verhofstadt-III kon worden gevormd. Die werd nadien opgevolgd door de regeringen-Leterme I, -Van Rompuy I en -Leterme II. Nadat ook deze regering op 26 april 20 Io ontslag diende te nemen en er op I3 juni 2oro opnieuw verkiezingen werden gehouden, brak de langste periode van regeringsvorming uit de Belgische geschiedenis aan. Het wereldrecord regeringsvorming werd inmiddels in het Guinness Book of Records opgetekend. Op I september, de dag dat deze bijdrage werd ingeleverd, was ons land reeds 492 dagen zonder volwaardige regering. Al die tijd stond de Koning op het voorplan. Alle registers van de regeringsvorming werden bespeeld. Zowel in de crisis van 2007, als in deze van 20I0-20II was Albert II niet slechts een 'onbewogen beweger'. Hij was niet de seismograaf, die slechts de politieke trillingen registreerde en omzette in initiatieven. Hij kon zich dat niet veroorloven. Zo werkte het niet. Hij zag zich verplicht zich te engageren. Hij nam wel degelijk op 'uitgesproken en zichtbare wijze, aan het politieke spel deel'. Hij werd bij momenten ook de speelbal van de politiek. Greep op de gebeurtenissen kreeg hij nauwelijks. Hij onderging ze veelal. Nooit was de crisis zo diep en zo verontrustend als de voorbije vier jaar. Ieder beseft uiteraard dat dit niet te

95 C.M.J. Schuyt, De traditie van het Koningschap, in D.J. Elzinga, De Nederlandse constitutionele monarchie in een veranderend Europa, Kluwer, Alpen aan de Rijn, 2006, p. 44. 'Juist door een zekere afstandelijkheid en neutraliteit kan hij binnen de politieke strijd een bindende rol vervullen, de continuïteit ervan mee verzekeren en het gezag ervan helpen overeind te houden. ... Die neutraliteit blijkt uit de terughoudendheid van de koning bij de ontvangst van informateurs en formateurs. Zo is de huidige koning zelf bij dat soort gelegenheden zelf niet in beeld en ziet men slechts de informateur de trap naar het paleis bestijgen of afdalen. Het is deze die al dan niet een verklaring aflegt, de koningin doet er wijselijk het zwijgen toe.' 
wijten is aan de rol die de Koning speelt, maar wel aan de regimecrisis waarin België is terecht gekomen.

De regeringsvorming in 2007 en in 20I0-20II is dus enigszins atypisch. Toch zullen we hierna op die recente gebeurtenissen ingaan omdat ze, op een verhevigde wijze aangeven dat een apolitieke Koning het risico loopt bij een regeringsvorming in het politieke strijdgewoel terecht te komen.

De Koning op het voorplan...

\section{a De raadplegingen}

-24. Na het ontslag van de regering vat de Koning de gebruikelijke raadplegingen aan..$^{6} \mathrm{Hij}$ ontvangt de ontslagnemende eerste minister, de voorzitters van de Kamer en de Senaat en vervolgens ook de voorzitters van de politieke partijen. ${ }^{97}$ Soms blijft het daar niet bij en worden nog andere politici gehoord, en soms ook de gouverneur van de Nationale Bank of de voorzitters van werkgevers- of werknemersorganisaties enz. De Koning bepaalt autonoom zijn raadplegingen. ${ }^{98}$ Hij alleen beoordeelt het nut ervan. Niet alle partijen worden, in elke fase van de formatie, op strikt gelijke wijze behandeld. Dat veroorzaakt al eens tandengeknars en leidde in 2007 zelfs tot een Open Brief aan de Koning in een krant. ${ }^{99}$ Het zou o.i. wenselijk zijn het als een ongeschreven regel van het formatieberaad te beschouwen dat de Koning alle voorzitters van de politieke partijen met zetels in het parlement, raadpleegt. ${ }^{\text {Ioo }}$ Hij moet immers een adequaat beeld krijgen van wat de volksvertegenwoordiging wenst. Als neutrale procesbegeleider van de regeringsvorming kan hij geen partijen weren bv. omdat ze het einde van België of van de monarchie nastreven. Dat doet hij overigens ook niet. Uiteraard is de Koning niet verplicht iemand uit te nodigen die al van te voren aankondigt dat hij niet zal komen of dat hij op geen enkele wijze aan de vorming van een Belgische regering wenst deel te nemen. Dat is wellicht de reden waarom de voorzitters van het Vlaams Blok en later het Vlaams Belang nooit ten Paleize werden ontvangen. ${ }^{\text {ro }}$ Bij elke regeringsvorming komt het ook voor dat par-

96 P. Lemmens, 'De raadplegingen van de Koning bij het begin van een regeringscrisis', Jura Falc. I976-1977, p. 407-426.

97 Voor de Tweede Wereldoorlog werden ook in België veeleer de fractievoorzitters geraadpleegd. Daardoor kwam de Governmentmaking power van het parlement meer tot zijn recht. Via de fractievoorzitters kreeg de Koning te horen wat het parlement zelf wilde. Na de oorlog eiste de particratie steeds meer haar rechten op. Zie de treurnis daarover bij P. Wigny, Droit constitutionnel, Principes et droit positif, Brussel, Bruylant, I952, I, p. 458-459.

98 Delpérée schreef dat de Koning raadpleegt 'qui il veut, quand il veut, où il veut et de la manière qu'il veut.' F. Delpérée, 'Le droit constitutionnel et les crises ministérielles', Bull. Acad. royale de Belgique, I988, nr. 5, p. I63; zie ook A. Molitor, La fonction royale en Belgique, p. 33: 'Il faut souligner que le Roi reste libre de ses consultations.'

99 Tijdens de regeringsvorming publiceerde LDD-voorzitter Jean-Marie Dedecker een open brief aan Koning Albert. Zie De Morgen, I3 november 2007.

Ioo In Nederland lijkt dit te zijn verworven. In I998 erkende minister-president Kok zelfs dat indien de koningin in afwijking van de bestaande praktijk slechts enkele fractievoorzitters zou raadplegen, de premier daarover verantwoording verschuldigd zou zijn. Handelingen, II, I997-I998, p. 4027-4028.

IOI Stichter-voorzitter Karel Dillen verklaarde lang geleden dat hij nooit naar het Paleis zou gaan als hij daartoe werd uitgenodigd. G. Polspoel en P. Van den Driessche, Koning en onderkoning. 
tijvoorzitters die in de eerste ronde van de raadplegingen wel werden gehoord, in een tweede of een derde ronde, niet meer worden uitgenodigd, omdat het gelet op de aan de Koning door de andere partijvoorzitters verstrekte adviezen, op dat ogenblik niet nuttig voorkomt. Ook dat is uiteraard volstrekt normaal.

-25. In België worden de door de partijvoorzitters aan de Koning verstrekte adviezen niet openbaar gemaakt. Daar wordt ook niet voor gepleit. De politieke partijen vragen er niet om. Wellicht vrezen ze dat een voortijdige bekendmaking van hun initiële standpunten hun onderhandelingsmarge aantast en de compromisvorming niet bevordert. De bekendmaking zou uiteraard de transparantie van de regeringsvorming wel ten goede komen. De Commissie Biesheuvel die in 1970 in Nederland de openbaarheid aanbeval, ${ }^{102}$ argumenteerde dat 'de kiezers er recht op hebben te weten wat er met hun stem gebeurt.' De openbaarmaking van de adviezen zou ook de mythe over de manoeuvreerruimte van de Koning tot haar ware proporties terugbrengen, door bloot te leggen dat een kabinetsformatie vooral een onderhandelingsproces is tussen politieke partijen. ${ }^{103}$ In België lijkt echter het gevoelen te overheersen dat het noch voor de democratie, noch voor de monarchie wenselijk is dat de onderhandelingen op straat worden gevoerd. Ook het risico dat een N-F-patstelling openlijk zou blijken, wordt wellicht geducht. De adviezen zijn dus alleen voor de Koning bestemd. Hij is door een discretieplicht gebonden. De politici weten dat. Ze spreken vrijmoedig. De koning, en zijn kabinetschef, die soms bij de gesprekken aanwezig is, zijn daardoor beter dan wie ook op de hoogte van de in and outs van de politieke toestand.

\section{b Het uitsturen van een 'wegbereider'}

-26. Op grond van de hem verstrekte adviezen, zal de Koning een initiatief nemen. Elke crisis is anders. De kaarten zijn steeds weer anders geschud. Soms is het te volgen tracé evident, soms liggen nog vele wegen open. Strikte regels zijn er niet. De Koning is bv. niet verplicht om de leider van de grootste partij een opdracht te geven, als vaststaat dat die toch niet kan slagen. ${ }^{104} \mathrm{Hij}$ zal iemand slechts het veld insturen als er een kans is dat die de regeringsvorming vooruit kan helpen. Tijdens de lange regeringscrisissen in 2007 en 2010-20II is gebleken dat het Hof over heel wat creativiteit beschikt in het steeds weer bedenken van nieuwe titels. Naast informateurs, preformateurs en formateurs, werden ook bemiddelaars en onderhandelaars, verkenners en verduidelijkers uitgezonden. Ook is gebleken dat de Koning wel kan pogen de regie te voeren, maar dat hij afhankelijk is van de bereidheid van de

Over de invloed van het Hof en de macht van Jacques van Yperseele de Strihou, Van Halewyck, 200I, p. II4.

I02 Rapport Openbaarheid Openheid I970.

I03 Zie in die zin J.J. Vis, 'Vrijheid en verantwoordelijkheid bij de kabinetsformatie', in Vrijheid en recht. Opstellen aangeboden aan prof. mr. E.H. s'Jacob ter gelegenheid van zijn aftreden als hoogleraar aan de Rijksuniversiteit van Groningen, Zwolle, W.E.J. Tjeenk Willink, I975, p. 35I359 .

I04 Zie daarover het debat in de Kamer naar aanleiding van de regeringsvorming van I924. J. Velaers, Albert I. Koning in tijden van oorlog en crisis, Lannoo, 2009, p. 638-643. 
politieke klasse om zijn regieaanwijzingen te aanvaarden. Die bereidheid lijkt af te nemen. In een boek over de recente regeringscrisis schrijven de journalisten Samyn en Buxant 'dat er steeds minder politici zijn die aarzelen om voorstellen of denksporen van het paleis af te wijzen. Iets wat in een niet zo ver verleden ondenkbaar was.' ${ }^{\text {I05 }}$ Vooraf moet de Koning zich er dan ook van vergewissen of zijn initiatief in goede aarde zal vallen. Gewezen eerste minister Martens getuigt: 'Voor het paleis een initiatief neemt, gaat men na of alle betrokken partijen er zich in kunnen vinden. Dat was vroeger niet zo. Tegenwoordig loopt het hof het risico dat iemand die wordt aangezocht voor een opdracht als bemiddelaar of informateur wordt teruggefloten door zijn partij.' ${ }^{\text {'06 }}$

\section{c De omschrijuing van de onderhandelingsruimte}

-27. Merkwaardig is ook dat de Koning vaak zeer ver gaat in het precies omschrijven van de opdracht die hij geeft. In een communiqué van het Paleis wordt dan vermeld met hoeveel partijen er zal worden onderhandeld, welk timing moet worden geëerbiedigd en zelfs waarover de onderhandelingen moeten gaan. ${ }^{107}$ Wellicht is de achterdocht tussen de partijen vaak zo groot dat zij het speelveld niet wensen te betreden vooraleer de koning het heeft afgebakend. Deze 'instrumentalisering' van het staatshoofd houdt risico's in. De Koning begeeft zich op politiek glad ijs. Zijn instructies worden immers niet altijd in dank aanvaard. In het najaar van 2007 bv. toen de onderhandelingen over de staatshervorming vastliepen en formateur Leterme leek te mislukken, nam de Koning het opmerkelijke initiatief om in een communiqué van het Paleis ${ }^{108}$ aan te geven dat hij aan de voorzitters van Kamer en

I05 S. Samyn en M. Buxant, Koning zonder land. De toekomst van de Belgische monarchie in woelige tijden, Amsterdam, De Bezige Bij, 201 , p. I6.

Io6 'Serviteur de l'Etat van de bovenste plank', in De Morgen, 29 augustus 2007.

I07 Deze communiqués worden gepubliceerd op de website www.monarchie.be. Zie bv. Communiqué 29 augustus 2010 'De Koning heeft (....) de h. Di Rupo gevraagd zijn opdracht verder te zetten: in het bijzonder over: BHV; de herfinanciering van Brussel; de modaliteiten van de voorbereiding van de nieuwe financieringswet op basis van de 12 overeengekomen principes en over de banden tussen deze 3 onderwerpen om het vertrouwen tussen de onderhandelaars te herstellen. Door het bijeenbrengen van de sociale partners om met hen te spreken over de materies die hen meer direct aanbelangen.' Communiqué io oktober 20Io 'De Koning heeft hem [de heer De Wever] gevraagd een verduidelijkingopdracht van tien dagen te vervullen met de zeven partijen die rond de tafel zaten om de standpunten dichter bij elkaar te brengen.'

Communiqué 29 oktober 2010: 'De Koning heeft deze namiddag de Heer Johan Vande Lanotte belast met een bemiddelingsopdracht. Zijn eerste doel zal zijn het vertrouwen te herstellen. Op basis van de werkzaamheden van de verduidelijker, de bemiddelaars en de preformateur wordt hij belast met het testen van de verschillende hypothesen die zijn voorgesteld aangaande de financieringswet, ten einde de financiële gevolgen ervan voor het federale niveau en de gefedereerde entiteiten te voorspellen. Hij zal ook nagaan of deze ramingen te verzoenen zijn met de I2 overeengekomen principes. Hij zal dit werk uitvoeren in samenwerking met de Nationale Bank en het Planbureau. Bovendien, zal de bemiddelingsopdracht ook de andere domeinen beslaan, behandeld door de 7. (...)' Communiqué 22 juli 20II: ‘(...) De Koning stelt voor een pauze tot midden augustus in te lassen in de onderhandelingen. De discussies zullen hervat worden op basis van de organisatie van de werkzaamheden zoals de formateur het heeft voorgesteld na de vergadering van deze nacht met de acht partijvoorzitters. De pauze zal gebruikt worden om verschillende wetsontwerpen door de juridische dienst van de Kamer te laten onderzoeken.'

Io8 Communiqué 8 november 2007: 'Dhr Leterme heeft een zesde verslag uitgebracht over zijn opdracht. De Koning heeft hem gevraagd zijn opdracht verder te zetten, zodat er vlug een federale 
Senaat zou vragen om de dialoog over de staatshervorming op te starten, zodat de formateur zich kon focussen op de regeringsvorming. Merkwaardig, een koning die de voorzitters van Kamer en Senaat een opdracht geeft. ${ }^{\text {I09 }}$ Reeds een dag later liet de partij van formateur Leterme weten dat ze dit niet zag zitten. Ze eiste dat de staatshervorming bleef deel uitmaken van de regeringsonderhandelingen. Iets gelijkaardigs deed zich voor in de zomer van 20 Io toen de Koning aan preformateur Di Rupo vroeg zijn opdracht voort te zetten en o.m. 'de autonomie en de responsabilisering van de gefedereerde entiteiten voor hun nieuwe bevoegdheden' uit te diepen. ${ }^{\text {IIo }}$ [onze cursivering] Meteen lieten Vlaamse onderhandelaars weten dat ze het daarmee niet eens waren en dat de autonomie en de responsabilisering ook voor de oude bevoegdheden moest gelden.

\section{d Het vasthouden aan een gegeven opdracht}

-28. Naarmate de crisis langer duurde en uitzichtlozer werd, leek de Koning wanhopiger te worden en was hij niet langer bereid zich, zonder meer, bij mislukkingen neer te leggen. Zo weigerde Albert II tot driemaal toe een ontslag te aanvaarden en drong erop aan een nieuwe poging te wagen. ${ }^{\text {III }}$ Ook aarzelde hij niet om soms zijn eigen gewicht in de schaal te werpen, opdat een formatiepoging zou slagen. Zo was hij in de zomer van $\mathbf{2 0 0 7}$, toen de onderhandelingen over een rooms-blauwe regering op een mislukking afstevenden, bereid om naast formateur Leterme te gaan staan en door raadplegingen de formatiepoging alsnog een kans te geven. ${ }^{\mathrm{II}}$ Het leverde hem de banbliksems op van de socialisten ${ }^{113}$ en in de pers het epitheton ornans 'de koning-formateur', 'le roi-formateur'. In de zomer van 2010 deed zich iets gelijk-

regering zou kunnen gevormd worden. Dit is van belang voor de welvaart van alle burgers van ons land, voor de geloofwaardigheid van België en zijn noodzakelijke cohesie. Anderzijds, zal de Koning dit weekend de Voorzitters van de Kamer van volksvertegenwoordigers en de Senaat ontvangen om hen te vragen een dialoog te starten over een evenwichtige verdere uitbouw van onze instellingen en de versterking van de cohesie tussen de gemeenschappen. Intussen zal de formateur voorbereidende bilaterale gesprekken hebben met de vier delegatieleiders.' Zie ook nog de communiqués van II, I3 en 23 november 2007.

Io9 Zie de kritiek van L. Tobback: 'Sinds wanneer komt het de koning als hoofd van de uitvoerende macht toe om aan de voorzitters van de wetgevende macht (...) op te dragen wat zij wel en niet moeten doen. Noem mij een dinosaurus die niet mee is maar voor mij is dat nieuw.' Het Nieuwsblad IO-II november 2007.

IIo Communiqué I8 augustus 20I0: ‘(..) de Koning heeft de Heer Di Rupo gevraagd zijn opdracht verder te zetten vanaf zaterdag en in het bijzonder de hiernavolgende domeinen uit te diepen: - de autonomie en de responsabilisering van de gefedereerde entiteiten voor hun nieuwe bevoegdheden om de bloei van elke entiteit mogelijk te maken; - de duurzame financiering van de federale staat voor de bevoegdheden en verplichtingen die hij zal blijven op zich nemen.'

III Communiqué 29 augustus 20I0: '(....) De Heer Di Rupo heeft aan de Koning gevraagd van zijn opdracht te worden ontheven. De Koning heeft geweigerd en heeft hem gevraagd zijn opdracht verder te zetten. (...)'; Communiqué II januari 201 I waarin J. Vande Lanotte aanvaaardt zijn ontslag weer in te trekken; Communiqué 22 juli 20 I waarin de Koning het ontslag van formateur Di Rupo weigert.

II 2 Het communiqué van het Paleis van 17 augustus 2007 luidde als volgt: 'Dhr Leterme heeft verslag uitgebracht over de evolutie van zijn opdracht. Naar aanleiding van dit verslag voert de Koning de komende dagen politieke raadplegingen. Gedurende die periode zullen de onderhandelingen in Hertoginnedal worden opgeschort.'

II3 'SP.A-voorzitter Johan Vande Lanotte vindt dat het Paleis een onaanvaardbaar initiatief neemt door oranjeblauw te hulp te komen', De Standaard, I8-Ig augustus 2007. 
aardigs voor. Nadat uit het verslag van preformateur Di Rupo bleek dat er vooruitgang was geboekt, vroeg Albert hem zijn opdracht verder te zetten, terwijl hij zelf toezegde vooraf de onderhandelende partijvoorzitters nog even te ontvangen. ${ }^{\text {II4 }}$ De koning stelde zich dus op als een loyale partner van zijn opdrachthouders. Alhoewel een dergelijke actieve deelname aan het proces van onderhandelingen ook al ten tijde van koning Boudewijn is voorgekomen, ${ }^{115}$ lokt ze steevast de kritiek uit dat het staatshoofd partijdig is, dat het niet aan hem toekomt om in de politieke arena af te dalen om een bepaalde coalitie mogelijk te maken.

\section{e De politieke klasse kapittelen}

-29. De regeringscrisis van 20I0-20II was bij het indienen van deze tekst op I september 20II nog lang niet beslecht. Net zoals koning Boudewijn in het verleden had gedaan, vond ook koning Albert II het nodig om de politieke klasse ten aanzien van de publieke opinie te kapittelen en terecht te wijzen als de verantwoordelijke voor de impasse. Op 3I maart I98I, enkele uren na de val van het kabinet-Martens IV ontbood Boudewijn negentien politieke, patronale en syndicale leiders in het paleis om hen op ongewoon scherpe wijze de levieten te lezen. De Koning zei: 'Het is nu de hoogste tijd om geschillen, van welke aard ook, aan de kant te schuiven en voorrang te geven aan de overleving. Dat is wat wij zouden doen indien we in oorlog zouden zijn. Welnu, het is oorlog: oorlog voor het behoud van onze economie, voor het welzijn van allen en vooral van de minderbedeelden, voor onze plaats in de wereld. Nog een opmerking waaraan ik groot belang hecht: de stabiliteit van de regering moet worden hersteld. In zeven jaar tijd hebben zeven regeringen elkaar opgevolgd, en dat in de moeilijkste tijden van de naoorlogse periode, nu wij meer dan ooit behoefte hebben aan stabiliteit en continuiteit.' Zijn toespraak werd in de pers bekendgemaakt. ${ }^{116}$ Recent maande ook Koning Albert zowel in de kersttoespraak van 2010, als in de 2I-juli-toespraak van $201 \mathrm{I}$ de politici sterk aan om een compromis te sluiten over de staatshervorming en een regering te vormen. ${ }^{\text {Ir7 }}$ In 2010 hield hij hun voor dat alle elementen op tafel lagen om een grondige hervorming van de staat te verwezenlijken en hij riep hen op de moed op te brengen om de nodige toegevingen te doen. In 20II legde de Koning met nauwelijks verholen onbegrip uit dat het nu wel lang genoeg had geduurd. 'Ik zou me aan mijn taak onttrekken', aldus de Koning, 'mocht ik nalaten aan de risico's te herinneren die alle Belgen lopen bij een langdurige crisis, en ook, mocht ik niet opnieuw aandringen bij alle politici, en bij hen die ze kunnen helpen, zich constructief op te stellen en snel een evenwichtige oplossing uit te werken voor onze problemen.'

II4 Communiqué I8 augustus 20I0. 'Daarom heeft de Koning de Heer Di Rupo gevraagd zijn opdracht verder te zetten vanaf zaterdag .... Donderdag en vrijdag zal de Koning de partijvoorzitters ontvangen, die deelnemen aan de onderhandelingen.'

II5 In 1978 bemiddelde de Koning bij de partijvoorzitters na het mislukken van het Egmontpact en in 1992 hielp hij formateur M. Wathelet door zelf gesprekken te voeren tijdens diens formatiepoging.

II6 V. Nees (red.), Wij, Boudewijn, Koning der Belgen. Het politiek, sociaal en moreel testament van een nobel vorst, Uitg. Editions, 1996, deel 2, p. I028-1029.

II7 Zie voor deze toespraken de website www.monarchie.be. 


\section{$f$ De keuze van de ministers}

-30. Wanneer dan uiteindelijk de regeringsvorming rond is, moeten nog de ministers worden aangeduid. In de aanvangsjaren van de coalitiedemocratie, in het interbellum, had de vorst nog wel invloed op de keuze van de ministers. Geleidelijk aan nam de particratie echter toe. Aanvankelijk werd hier nog tegen geprotesteerd. ${ }^{\mathrm{I}}{ }^{8}$ Zo waarschuwde de commissie-Soenens er in 1949 voor dat 'in een zo kiese aangelegenheid als deze der benoeming en der afzetting der ministers, de invloed (van de politieke partijen) zich met mate moeten laten gelden.' Steeds meer slaagden de partijen er echter in het laken naar zich toe te halen. Sinds de beruchte uitspraak van de PS-voorzitter Spitaels, die na de moord op zijn voorganger A. Cools, verklaarde 'Il m'a fait ministre', doen de politici steeds minder moeite om de schijn hoog te houden. Rimanque en Wouters schreven terecht: 'Een van de meest flagrante voorbeelden van de kloof tussen de formele fictie en de politieke realiteit is precies de grondwetsbepaling die de koning het recht toekent zijn ministers te benoemen. In praktijk onderhandelen de partijen van de nieuwe meerderheid over de onderlinge verdeling van de ministerposten en beslist elke partij vervolgens zelf wie voor haar in de regering zal zetelen."119 Weliswaar worden er ook voor de naoorlogse periode nog steeds voorbeelden aangehaald van kandidaat-ministers die op het veto van de Koning zouden zijn gestuit. ${ }^{20}$ Vaak gaat het om hardnekkige geruchten, die moeilijk zijn te verifiëren, zolang de archieven gesloten zijn. ${ }^{21}$ Steeds rijst de vraag of het werkelijk om een koninklijk veto ging, dan wel om een aanbeveling, een wens, een suggestie van de koning waarmee de formateur bereid was rekening te houden. Omgekeerd komt het trouwens ook voor dat de Koning deze of gene politicus overtuigt om een ministerportefeuille te aanvaarden. ${ }^{122}$

B De ministeriële verantwoordelijkheid een fictie, de Kroon ontbloot, de onschendbaarheid onder druk

a De ministeriële verantwoordelijkheid een fictie

-3I. Tijdens de regeringsvorming neemt de Koning voortdurend uitgesproken politieke beslissingen. De vraag rijst dan ook op welke wijze de ministeriële

II8 Zie bv. G. Van den Bossche, 'Autour du parlementarisme. Le mode de nomination des ministres', Rev. Belge, I929, p. I09-I2I.

II9 K. Rimanque en M. Wouters, 'Het optreden van de koning in België, in het bijzonder tijdens regeringscrisissen', o.c., p. I20.

I20 Zo zou Koning Albert II in de regeringsvorming van I999 de PS-politicus Michel Daerden hebben afgewezen. Y. Monette, Métier de Roi, Famille. Entourage. Pouvoir. de A à Z, Brussel, 2002, p. I8o, tw. Roi \& Gouvernement, die ook andere voorbeelden uit de regeerperiode van Koning Boudewijn vermeldt. Zie ook R. Senelle, M. Clement en E. Van de Velde, Handboek voor de Koning. Lannoo, 2004, p. 202-203.

I2I Lange tijd werd voor waar aangenomen dat Koning Boudewijn een veto zou gesteld hebben tegen VU-er Frans Baert als minister van Justitie. In zijn Mémoires maakt toenmalig eerste minister Leo Tindemans er echter geen gewag van. Hij vermeldt wel dat de koning zich verzette tegen Leon Hurez als vicepremier, maar dit verzet moest opgeven onder druk van PS-voorzitter Cools. L. Tindemans, De Mémoires. Gedreven door een overtuiging, Lannoo, 2002, p. 335-336.

I22 Zo ontblootte eerste minister Martens in 1988 de kroon door te onthullen dat de koning hem had overtuigd premier te blijven. 
verantwoordelijkheid wordt ingevuld. Dit blijft een pijnpunt van de constitutionele monarchie. Het antwoord dat het staatsrecht geeft, is weinig overtuigend. In België wordt de ontslagnemende eerste minister geacht de ministeriële verantwoordelijkheid te dragen. Zijn regering is immers met de lopende zaken belast. De regeringsvorming behoort daartoe. ${ }^{123}$ Dat impliceert uiteraard niet dat de Koning voor elk initiatief dat hij neemt, vooraf door de ontslagnemende eerste minister gedekt dient te zijn. Diens rol blijft beperkt. Hij is er nog en is beschikbaar voor overleg. ${ }^{124}$ Veelal blijft hij echter op afstand. Zijn positie als ontslagnemend regeringsleider die vaak niet meer het vertrouwen geniet van de meerderheid, is niet van dien aard om de regeringsvorming te kunnen begeleiden. Hij wordt dan ook als zodanig niet bij de koninklijke initiatieven betrokken, tenzij hijzelf tot informateur of formateur wordt aangeduid. De ministeriële verantwoordelijkheid heeft hier dan ook slechts een beperkte en in grote mate louter formele draagwijdte. Een geslaagde regeringsvorming eindigt in België in een reeks koninklijke besluiten. Eerst benoemt de Koning de nieuwe eerste minister. Het besluit daartoe wordt tegengetekend door de ontslagnemende premier. Vervolgens aanvaardt de Koning het ontslag van de ministers van de vorige regering. Het besluit daartoe wordt mede ondertekend door de nieuwe eerste minister. En ten slotte worden ook de overige ministers benoemd met een besluit dat eveneens door de nieuwe eerste minister wordt ondertekend. Zo is de cirkel rond en zou het optreden van de koning gedekt zijn: de gewezen eerste minister draagt de verantwoordelijkheid voor de regeringsvorming en dus voor alle initiatieven die de Koning heeft genomen ${ }^{125}$ en de nieuwe eerste minister voor de concrete samenstelling van de regering. ${ }^{26}$

-32. Deze constitutionele gewoonte dateert van I87I toen koning Leopold II een katholieke regering die nog over een meerderheid in het parlement beschikte, ten val bracht, om ze te vervangen door een andere katholieke regering. ${ }^{127}$ Zowel

I23 B. Waleffe, Le roi nomme et révoque ses ministres, Brussel, Bruylant, I97I, p. 46, nr. 37.

I24 Delpérée schrijft zelfs dat de ontslagnemende ministers dicht bij het Paleis blijven 'et peuvent à ce moment avaliser les démarches qui sont accomplis (...)', F. Delpérée, 'Le roi règne et ne gouverne pas', JT, I990, p. 703.

I25 Zie E.M. Martens in een antwoord op een parlementaire vraag van de h. Cortois. Parl. Hand., Kamer, I2 oktober I989, p. 30 en v.: 'Dat betekent dus ook dat de raadplegingen met het oog op de vorming van de nieuwe regering, politiek volledig zijn gedekt door de aftredende Regering en meer bepaald door de aftredende Eerste Minister.'

I26 Hij is er m.n. voor verantwoordelijk dat er slechts Belgen worden benoemd (art. $97 \mathrm{GW}$ ), geen kinderen van de Koning (art. $98 \mathrm{GW}$ ), dat er maximaal 15 ministers zijn, en dat de pariteit in de ministerraad wordt geëerbiedigd (art. 99).

I27 In I87I werd de regering-d'Anethan opgevolgd door de regering-de Theux en in I884 de regering-Malou door de regering-Beernaert. De constitutionele verwikkelingen die daarmee gepaard gingen, hebben geleid tot gewoonten die nog steeds deel uitmaken van ons grondwettelijk recht. Tot I87I was het de praktijk dat de gewezen regeringsleider zowel de benoeming van zijn opvolger, als het ontslag van zijn collega-ministers tegen tekende. Deze procedure was nog gevolgd bij de opvolging van de regering Frère-Orban door de regering-d'Anethan (zie Mon. B., 3 juli 1870). Omdat d'Anethan het niet eens was met de regeringswissel die de Koning had opgedrongen weigerde hij echter zijn handtekening. Uiteindelijk werd een compromis bereikt. De katholiek de Theux werd eerst tot minister benoemd in een besluit dat door d'Anethan werd tegen getekend. Vervolgens tekende de Theux de besluiten waarmee het ontslag van de regering 
in $187 \mathrm{I}^{\mathrm{I} 28}$ als later in $\mathrm{I} 884^{\mathrm{I} 29}$ - toen ongeveer hetzelfde zich herhaalde - werd er in de Kamer uitvoerig gedebatteerd over de draagwijdte van de ministeriële verantwoordelijkheid. ${ }^{130}$ Voor het eerst werd het standpunt verdedigd dat later uitgroeide tot de nog steeds geldende theorie. De regeringsleider die de benoeming van zijn opvolger mede ondertekent, neemt niet elk aspect van de regeringsvorming voor zijn rekening. Hij bevestigt slechts dat deze op constitutioneel regelmatige wijze is verlopen. Hij kan zijn handtekening slechts weigeren indien dat niet het geval is. Aangezien er voor de regeringsvorming nauwelijks regels bestaan, behoudens dan het beginsel van het parlementair systeem, zou de gewezen regeringsleider zijn handtekening slechts kunnen weigeren indien de Koning een regering vormt die niet door een meerderheid in de Kamer wordt gesteund of minstens gedoogd. ${ }^{\mathrm{I}}{ }^{\mathrm{I}}$ Indien de gewezen regeringsleider ten onrechte zijn handtekening weigert en ook in geval van overmacht, ${ }^{132}$ kan de nieuwe regeringleider de eigen benoeming mede ondertekenen. ${ }^{\mathrm{I} 33}$

-33. Dit alles kan niet verhelen dat er geen minister reëel verantwoordelijk is voor de vele ingrijpende beslissingen die de koning met het oog op de regeringsvorming neemt. Hij handelt dan als 'een koorddanser zonder net'. Valt hij, dan belandt hij niet in het veilige net van de ministeriële verantwoordelijkheid. Die is in deze periode 'assez fictive', schrijft André Molitor. ${ }^{\mathrm{I} 4}$ Eigenlijk wordt de Koning vooral gedekt door het resultaat van de regeringsvorming. Wanneer er uiteindelijk een regering

d'Anethan werd aanvaard en waarmee de andere ministers uit zijn regering werden benoemd (Mon. B. 7 december I87I). Dit stramien groeide uit tot een grondwettelijke gewoonte.

I28 Ann. Parl., Kamer, I87I-72, I2 december I87I, II4-I26 en I3 december I87I, p. I29-I36.

I29 Ann. Parl. Kamer, I884-I885, 20 tot 26 november I884.

I30 Zie J. Mertens, 'La nomination et la révocation des ministres', p. 380.

I3I P. De Visscher, 'La fonction royale', Rev.Gen., I949, 689: 'A notre avis, le Premier ministre sortant opposera un refus justifié au choix du Roi lorsque ce choix prétend s'exercer en opposition manifeste avec la volonté non équivoque de la majorité parlementaire.'

I32 Bijvoorbeeld wanneer in oorlogstijd de koning en de ministers geen contact meer hebben. In juni I940 had dit kunnen worden toegepast, maar - Culpa felix - koning Leopold III werd hierover toen slecht geadviseerd door advocaat-generaal bij het Hof van Cassatie Hayoit de Thermicourt. Zie J. Velaers en H. Van Goethem, Leopold III, de koning, het land, de oorlog, Lannoo, I994, p. 247-250; J. Stengers, De koningen der Belgen, p. 44-47. Zie echter anders procureur-generaal F. Dumon, 'Over enkele grondwettelijke problemen gerezen tijdens de tweede wereldoorlog', Mededelingen van de Koninklijke Academie voor wetenschappen, letteren en schone kunsten van België, Klasse der Letteren, $1983 / 2$, p. I-48.

I33 De Commissie-Soenens stelde: 'Naar een vast gebruik wordt het benoemingsbesluit van de eerste minister ondertekend door zijn voorganger die alzo de verantwoordelijkheid draagt van de grondwettelijke regelmatigheid van de wijze waarop de keuze van de Koning werd gedaan, en het is de nieuwe eerste minister die het besluit, waarbij ontslag van de uittredende eerste minister aanvaard wordt, alsmede de benoemingsbesluiten van zijn collega's, mede ondertekent. Nochtans in geval van niet gerechtvaardigde weigering van de Eerste Minister of in geval van heirkracht, moet de pas benoemde Eerste Minister zijn eigen benoeming mede kunnen ondertekenen.'

Deze laatste stelling werd eerder reeds in de rechtsleer verdedigd, zie de verwijzingen in J. Mertens, 'De grondwettelijke verantwoordelijkheid voor het ontslag en de benoeming van ministers', RW, I946-I947, I77 en v.; A. Mast, 'La nomination et la révocation des ministres', J.T., I949, p. 649 en v., B. Waleffe, Le Roi nomme et révoque ses ministres, Brussel, Bruylant, I97I, nr. 35 en v., p. 43 en v., nr. 44 ,

I34 A. Molitor, La fonction royale en Belgique, p. 46. 
wordt gevormd die het vertrouwen van een meerderheid van de Kamer verwerft, verstomt de kritiek, althans bij de meerderheid. Enkel bij de minderheid - de (slechte) verliezers - blijft ze soms nog wat nasmeulen.

\section{b De Kroon ontbloot}

-34. Ook het Geheim van Laken is ten tijde van een regeringvorming in grote mate fictief. Alle initiatieven van de Koning zijn immers openbaar. Ze worden door communiqués van het Paleis bekendgemaakt. Het systeem verheelt niet dat het staatshoofd zelf aan zet is. ${ }^{135}$ Het volstaat enkele koppen van de kranten uit de recente periode te citeren om te beseffen dat die niet bepaald het beeld van een a-politieke Koning die niet verantwoordelijk is, aan de publieke opinie voorhouden: 'De Koninklijke marionet Albert', 'De Koning weet het ook niet meer', 'Albert en Didier, dikke vrienden', 'Questions sur le vice-roi', 'De truc met de Koning', 'Koning in oranje-blauw mijnenveld', 'Koning moet Milquet temmen', 'Koning brengt Leterme geen stap verder', 'Albert II, le Joker de Leterme', 'De Koning noodgedwongen op glad ijs', 'Hof brengt geen rust', 'Monarchie zaagt tak af waar ze op zit', 'Koning zet N-VA voor het blok', 'CD\&V'ers verwijten Koning paniekvoetbal', 'Ze spelen met de koning zijn voeten', 'De koning is meer splijtzwam dan bindteken', 'De Koning roept in de woestijn', 'Albert schroeit zijn vingers aan crisis', 'De Koning dreigde met staking', 'Vorst aan de grond', enz. Eigenlijk staan we voor een structurele ontbloting van de Kroon, waar soms nog een conjuncturele ontbloting door loslippige politici bijkomt. De discretieplicht maakt deel uit van ons grondwettelijk recht. Voor ministers is het een voorwaarde om de 'eenheid van de kroon' te waarborgen. Ze volgt rechtstreeks uit de artikelen 88 en 106 van de grondwet. Voor de overige gesprekspartners van de Koning gaat het veeleer om een ongeschreven regel. ${ }^{136}$ De huidige generatie politici lijkt echter steeds minder bereid om het vertrouwelijke karakter van hun gesprekken met de vorst te eerbiedigen. Al ten tijde van Koning Boudewijn poogde journalist Hugo De Ridder het verhaal over de regeringsvorming te schrijven op basis van wat loslippige politici hem daarover hadden verteld. Ook de rol van de Koning bleef daarin niet onbesproken. Toen in zijn boek 'Sire geef me honderd dagen' uit I989 voor het eerst een relaas was opgenomen over een gesprek dat Koning Boudewijn met de PSC-voorzitter Gerard Deprez had gevoerd, in het kader van een regeringvorming, fulmineerde eerste minister Martens in de Kamer dat dit 'schadelijk is voor de goede werking van de instellingen'. ${ }^{137}$ Sindsdien is het er niet op verbeterd. Ook

I35 R. Ergec en M. Uyttendaele, 'La monarchie en Belgique - Reflet du passé ou nécessité nationale?' in Présence du droit public et des droits de l'homme. Mélanges offerts à Jacques Velu, Brussel, Bruylant, I992, p. 608 : 'Aux moments les plus cruciaux de la vie politique nationale, un pouvoir d'initiative essentiel est conféré à quelqu'un dont l'autorité morale et constitutionnelle peut difficilement être contestée, mais qui à aucun moment n'est appelé à rendre compte des actes - parfois déterminants - qu'il prend.'

I36 Zie A. Molitor, La fonction royale en Belgique p. Ioo Wij zouden het veeleer een conventie noemen, die eenieder die aan een regeringsvorming deelneemt, geacht moet worden te kennen en vrijwillig te hebben aanvaard.

I37 E.M. Martens in een antwoord op een parlementaire vraag van de h. Cortois. Parl. Hand., Kamer, I2 oktober I989, p. 30 en v. 
over de recente crisis verschenen boeken met onthullingen over de Koning. ${ }^{13^{8}} \mathrm{De}$ betrokken journalisten zelf getuigen: 'Ooit was het colloque singulier heilig. Over gesprekken met de vorst werd niet uit de biecht geklapt. Dat beginsel staat al enige tijd onder druk. Er wordt steeds vaker en steeds sneller onthuld welke denksporen de vorst aftoetst.' De politici lijken de behoefte te hebben uit te bazuinen wat ze aan de koning hebben verteld en wat ze van de woorden van de vorst menen te hebben begrepen. ${ }^{139}$ In een fors communiqué van 5 mei 201 r betreurde het Paleis 'dat de discretie met betrekking tot het colloque singulier niet wordt gerespecteerd. Deze discretie heeft tot doel het Staatshoofd zijn functie te laten vervullen. Sommige van de gepubliceerde uittreksels bevatten manifeste onjuistheden, in het bijzonder over de onderhouden van i6 juni en 8 oktober 20ro.' Ook politici van de vorige generatie maken zich zorgen. Gewezen premier Marc Eyskens verklaarde: 'Dit zijn geen domme versprekingen of ijdele ontboezemingen, maar doelbewuste lekken om de koning te beschadigen en bepaalde politieke effecten te bekomen. Er is een ware striptease aan de gang in de Wetstraat, een politiek paaldansen zonder weerga. De onderliggende drijfveer kan alleen maar republikeinse drijverij zijn. ${ }^{{ }^{1} 40}$ Volgens gewezen SP-A-voorman Willy Claes respecteert de politieke wereld de prerogatieven van het staatshoofd niet langer. 'Ik weet alleen niet of dat met een gebrek aan kennis van onze instellingen dan wel met een teloorgang van de politieke deontologie te maken heeft. Maar de gevolgen zijn wel gevaarlijk: als men de koning schaak zet - schaakmat is het nog niet - dan blokkeert uiteindelijk alles.' ${ }^{\text {I4I }}$

\section{c De onschendbaarheid onder druk}

-35. De onschendbaarheid en onverantwoordelijkheid van de Koning zijn twee zijden van eenzelfde medaille. De Koning is onschendbaar; boven kritiek verheven, omdat hij niet verantwoordelijk is en een minister de verantwoording voor zijn daden draagt. Faalt de ministeriële verantwoordelijkheid dan incasseert de Koning zelf de kritiek. De persoonlijke inbreng van de Koning in de regeringsvorming maakt hem kwetsbaar. Dat is al zo sinds I9I8, toen de periode van de coalitieregeringen aanvatte. Van de eerste regeringsvorming onder Albert I - de 'staatsgreep van Loppem' - tot de huidige onder Albert II: nu en dan heeft er wel kritiek geklonken. Politici die uit de boot vielen, ventileerden hun frustraties en namen ook de Koning

I38 S. Samyn, W. Verschelden, B. Brinckman, I. Albers, De zestien is voor U, Lannoo, 2007, 335 p. S. Samyn en T. Peeters (red.), De gevangenen van de wetstraat. Een reconstructie van zeven maanden onderhandelen, Gent, Borgerhoff, 20II, p.I4I; S. Samyn en M. Buxant, Koning zonder land. De toekomst van de Belgische monarchie in woelige tijden, Amsterdam, De Bezige Bij, 2011, p. I6.

I39 Zo schrijven de auteurs dat de Koning het NV-A als staatsgevaarlijk beschouwt, dat hij er in 2007 voor pleitte het kartel tussen CD\&V en NV-A stop te zetten, en dat in 2010 aan Bart De Wever de titel bemiddelaar geweigerd werd omdat de kabinetschef vond dat die alleen aan ernstige mensen toekwam; dat hij in 2007 de Waalse socialisten niet terugwilde en in 2010 de liberalen lange tijd op afstand hield, omdat de PS hen afwees; dat hij in 2010 de voorzitter van de VLD Decroo verantwoordelijk hield voor de crisis en daarover zeer verbolgen was, dat hij 'vocht voor de federale kieskring', dat hij een lans brak voor het behoud van de tien federale wetenschappelijke instellingen, dat hij in 2oro heeft gezworen nooit verkiezingen toe te staan enz.

I40 'Lekken uit regeringsonderhandelingen zijn een gortige schande', De Morgen, I3 februari 2008.

I4I 'Discretie over rol koning is volledig verdwenen', De Morgen, 28 augustus 2007. 
in het vizier. In het verleden bleef die kritiek meestal binnenskamers. In de recente periode wordt ze ook openlijk geuit. ${ }^{\mathrm{I} 2}$ Vooral politici die republikein zijn, tillen daar niet zo zwaar aan, maar ook anderen aarzelen niet om van hun vrije meningsuiting gebruik te maken. Het gaat per slot van rekening toch om een aangelegenheid van publiek belang. De Koning wordt verweten op een bepaalde coalitie aan te sturen, de Vlamingen te bevoordelen, of omgekeerd de Koning van de Franstaligen te zijn, een bepaalde partij of politicus voor te trekken en een andere bewust te boycotten, te lang vast te houden aan één formule en een andere te vroeg uit te proberen om ze te doen mislukken, overhaast te handelen of te traag, niet voortdurend beschikbaar te zijn of zich te veel te engageren enz. Ook het entourage van de koning komt onder vuur te liggen. In de recente crisis nam vooral NV-A voorman Bart De Wever het Paleis op de korrel. Hij verweet de Koning o.m. dat die zijn opdracht als 'verduidelijker' wel erg strikt afbakende en hem te weinig tijd liet (tien dagen) en dat de N-VA daarenboven niet werd gehoord over de aanduiding van J. Vande Lanotte als bemiddelaar. ${ }^{\mathrm{I} 33}$ In een interview met Der Spiegel van I3 december 2010 verklaarde hij: 'Het is een probleem dat de koning nog een politieke rol vervult. Als er een crisis ontstaat, wint de koning aan belang. Hij neemt het voortouw van een regering. Voor de Vlamingen is dat een nadeel, omdat de koning anders denkt dan wij. Voor de Walen is het een voordeel, omdat zij met hem verbonden zijn. Wij zijn voorstanders van een republiek.' ${ }^{44}$ De dag later verklaarde hij aan 'La Libre Belgique': 'Est-ce que le Roi est du côté de ceux qui veulent des réformes et plus d'autonomie ? La réponse est non. Il est du côté de ceux qui veulent garder le statu quo. La monarchie est un atout pour les francophones qui veulent garder le statu quo.' ${ }^{\text {I45 }}$ Dat de Koning 'willens, nillens' in het politieke strijdgewoel terecht komt, is dus niet zonder collateral damage voor de koninklijke functie.

\section{Een dienst aan de democratie of een democratisch deficit?}

-36. De vraag rijst of het vanuit democratisch oogpunt aanvaardbaar is dat een niet verkozen staatshoofd een zo prominente rol speelt bij de regeringsvorming. De meningen zijn daarover verdeeld. Sommigen benadrukken steeds weer dat de koning geen doorslaggevende rol speelt. Hij werkt immers niet in het luchtledige, doch steeds in functie van de objectieve elementen van de politieke situatie. De Koning kan niets forceren. Zijn persoonlijke preferenties kunnen niet doorslaggevend zijn. ${ }^{146}$ De politiek is immers autonoom. Partijvoorzitters laten zich niets opdringen. Zij kunnen te allen tijde weigeren met een door de Koning aangewezen

I42 Zie F. Delpérée en B. Dupret, 'Nul ne peut découvrir la couronne', Les cahiers constitutionnels, I989, p. 4I.

I43 S. Samyn en T. Peeters, De gevangenen van de wetstraat, een reconstructie van zeven maanden onderhandelen, Borgerhoff \& Lamberigts, 20II, p. III-II2, p. I22-I 23.

I44 De Standaard, Letterlijk. Bart De Wever in Der Spiegel, I3 december 2010.

I45 La Libre Belgique, I4 december 20I0, L'interview de Bart De Wever, p. 4.

I46 Zie bv. A. Molitor, La fonction royale en Belgique, p. 37: 'La tâche du Roi sera donc d'opérer un arbitrage où ses désirs personnels seront un élément, mais un élément seulement.' 
(in)formateur in zee te gaan. ${ }^{\mathrm{I} 7}$ Ook al beschikt de Koning, afhankelijk van de politieke omstandigheden en de uitgebrachte adviezen, soms over enige vrijheid bij het nemen van initiatieven, het resultaat dient steeds te beantwoorden aan de wil van de politieke partijen die onderhandelen. Ultiem komt de Government making power toe aan de Kamer van Volksvertegenwoordigers die het vertrouwen aan de door de Koning benoemde ministers kan weigeren. ${ }^{\mathrm{I} 48}$ Gebeurt dat, dan dient de eerste minister meteen zijn ontslag aan te bieden. ${ }^{149}$ De rol die het staatshoofd speelt, bestaat er enkel in om wat 'mogelijk' is 'werkelijk' te maken, ${ }^{150}$ om eruit te halen wat erin zit. Hij speelt een initiërende, begeleidende en bevorderende rol die partijen helpt om afstanden te overbruggen en impasses te doorbreken. Zijn rol is vergelijkbaar met die van een vroedvrouw: hij is noch de vader, noch de moeder, hij heeft het kind niet verwekt en zal het ook niet baren, maar helpt het wel ter wereld brengen.

-37. Voor de anderen is het feit dat de Koning soms verplicht is keuzes te maken met politieke gevolgen, zonder dat een minister een reële verantwoordelijkheid draagt, voldoende om het over een 'democratisch deficit' te hebben. ${ }^{151}$ Een handige Koning zou trouwens in uiterst moeilijke omstandigheden er wel degelijk in kunnen slagen om de oriëntatie van de onderhandelingen te beïnvloeden en een oplossing naar voor te schuiven die overeenstemt met zijn wensen, ${ }^{152}$ of minstens een oplossing te weren die hij afwijst, zo wordt beweerd. En hoe dan ook, omdat de Koning onvermijdelijk in de politieke arena afdaalt, kan zijn neutraliteit in het gedrang komen. Ook de onschendbaarheid kan onder druk komen te staan. De Koning kan immers een gemakkelijk slachtoffer worden van personen die erop uit zijn het staatshoofd en de monarchie ter discussie te stellen. Van symbool van de eenheid, wordt hij dan oorzaak van verdeeldheid.

I47 Zie over de overwegende rol van de politieke partijen, K. Rimanque en M. Wouters, 'Het optreden van de koning in België, in het bijzonder tijdens regeringscrisissen', Res Publica, I99I/I, p. II9I2O.

I48 Het is een vaste regel van constitutioneel recht dat een regering slechts effectief het beleid mag voeren dat zij in een regeringsverklaring voorstelt, indien zij daarvoor in de Kamer hetvertrouwen heeft verkregen. L. Neels, Regeringsverklaringen en regeerakkoorden als documenten van toenemend publiekrechtelijk belang. Een nieuwe bron van publiek recht', R.W., I974-75, 23692410.

I49 In het verleden is gebleken dat het kan misgaan. Zo overleefde de regering-Van de Vyvere in I925 de vertrouwensstemming niet en diende al na een dag ontslag te nemen. 'Il était mort avant de vivre' grapte de pers. (Zie over de kroniek van deze aangekondigde dood J. Velaers, Albert I. Koning in tijden van oorlog en crisis, Lannoo, Tielt, 2009.) Met de huidige particratie komen dergelijke misslagen niet meer voor. Zodra de partij-instanties het licht op groen zetten, benoemt de Koning ‘zijn' ministers en schenkt ook het parlement hun steevast het vertrouwen.

I50 A. Molitor, La fonction royale en Belgique, p. 33.

I5I R. Ergec en M. Uyttendaele, 'La monarchie en Belgique - Reflet du passé ou nécessité nationale?' in: Présence de droit public, p. 607-6o8.

I52 F. Perin, 'Qui a fait et défait les gouvernements (I9I8-I958)', Courrier Hebdomadaire, I959, nr. 4, p. 4; F. Perin, La démocratie enrayée, Brussel, I960, p. 40; R.P.D.B., tw. Chef de l'Etat, t. I, 905: 'Le Chef de l'Etat n'est pas ici le simple enregistreur de la volonté parlementaire. Ses préférences, ses conceptions peuvent avoir une influence parfois très efficace sur la désignation ou l'élimination de certaines personnalités, voire sur le groupement des forces politiques appelées à soutenir le Cabinet.' 
-38. Voor wie binnen de context van een parlementair systeem nadenkt over alternatieven, dienen zich drie mogelijkheden aan: ofwel de Kamer van Volksvertegenwoordigers neemt zelf de initiatieven die tot de vorming van de regering moeten leiden, ofwel men belast een andere personaliteit daarmee, bijvoorbeeld de voorzitter van de Kamer, ofwel men laat de regeringsvorming over aan de spontane actie van de politieke partijen, die eventueel geholpen door een aantal procedurele richtlijnen zelf instaan voor de regeringsvorming.

-39. Een eerste alternatief dat soms naar voor wordt geschoven is dat de Kamer van Volksvertegenwoordigers de formatie tot zich zou trekken. Reeds in I97I drukte de Nederlandse Tweede Kamer in de motie-Kolfschoten ${ }^{153}$ de wens uit dat na de verkiezingen de nieuwe Kamer bij meerderheid een kabinetsformateur aan de koningin zou voorstellen. Die motie is nooit in de praktijk gebracht. In I97I probeerden de politieke partijen hetwel, maar ze kwamen er niet uit. Latere voorstellen in die zin $^{154}$ hadden evenmin enig gevolg. De idee leek te zijn afgevoerd, ${ }^{155}$ maar werd recent opnieuw opgevoerd in de nota 'Verbindend Koningschap in de Republiek' van de PvdA. ${ }^{56}$ Het komt ons voor dat het ook in België niet strijdig zou zijn met de grondwet indien de Kamer over de regeringsvorming een debat zou houden en in een resolutie een formateur aan de Koning zou voordragen. De reële Government making power komt immers toe aan de Kamer. Volgens artikel 96, eerste lid, GW moet de Koning de ministers wel benoemen. Op grond van een grondwettelijke gewoonte neemt hij ook zelf initiatieven die tot een regeringsvorming moeten leiden. Niets verzet er zich echter tegen dat de Kamer een meer actieve rol zou spelen. ${ }^{157}$ In 1993 werd al een tweede lid aan artikel 96 toegevoegd. Om de stabiliteit van de instellingen te

I53 Motie-Kolfschoten I8 februari I97I, Kamerstukken II I970/7I, Io 993, p. 9. Zie B.P. Vermeulen, A.P. Krijnen en D.A. Roos (red.), De Koning in het Nederlandse staatsrecht, Ars Aequi libri, Nijmegen, 2005, p. 88-89: 'Hierbij komt, dat - daargelaten de normering van het eindresultaat door de vertrouwensregel - de procedure inzake de kabinetsformatie niet door staatsrechtelijke normen, maar enkel door staatkundige praktijk beheerst wordt. De Tweede Kamer is derhalve vrij om de procedure zo in te richten dat de Koning daarin geen enkele rol speelt. Zo zou zij kunnen besluiten voortaan zelf een (in)formateur te benoemen of aan de Koning voor te dragen. Het is per slot van rekening aan de Tweede Kamer om op basis van de verkiezingsuitslag te bepalen welk kabinet er uiteindelijk wordt geformeerd.'

I54 Ook de Staatscommissie-Biesheuvel beval in I984 aan dat de Tweede Kamer de kabinetsformateur zou aanwijzen. In 1993 nam ook de Adviescommissie-De Koning deze idee over.

I55 Een motie-Kant/Halsema werd in 2000 afgevoerd. Kamerstukken II 2000-200I, 27400 III nr. 6 en Handelingen II, 2000-200I, p. 643.

I56 'Verbindend Koningschap in de Republiek.'Advies van de commissie ad hoc 'Actualisatie toekomst Koningshuis' van de Partij van de Arbeid, Amsterdam 24 augustus 201 I.

I57 K. Rimanque en M. Wouters, 'Het optreden van de koning in België, in het bijzonder tijdens regeringscrisissen', o.c., I28. 'De grondwet verzet zich evenmin tegen andere scenario's, waarin bij voorbeeld het parlement een actieve rol zou spelen. Indien parlementaire fracties een politiek akkoord sluiten en een formateur aan de koning voorstellen - naar analogie met de bestuursakkoorden en de voordracht van een burgemeester in de gemeenten - kan daar geen enkel grondwettelijk bezwaar tegen ingebracht worden. Dit alternatief lijkt echter moeilijk haalbaar in een communautair drieledig land met een stelsel van evenredige vertegenwoordiging en een grondwettelijk paritaire regering.' 
verhogen werd daarin bepaald dat de Kamer van Volksvertegenwoordigers door een constructieve motie van wantrouwen of door het constructief weigeren van het vertrouwen een regering ten val kan brengen. De Kamer kan bijgevolg het vertrouwen in de regering opzeggen en meteen een 'eerste minister' - eigenlijk gaat het om een kandidaat-eerste minister, een formateur - aan de Koning voordragen. In dat geval is het staatshoofd verplicht deze te benoemen. ${ }^{158}$ Tijdens de parlementaire voorbereiding van deze bepaling werd weliswaar uitdrukkelijk gesteld dat wanneer een regering ontslag neemt na verkiezingen of als gevolg van een crisis in de schoot van de regering zelf, de op het gewoonterecht gegronde prerogatieven van de Koning onaangetast blijven. ${ }^{159}$ Dat impliceert o.i. nog niet dat het gewoonterecht anno 1993 ook als zodanig in de grondwet zelf is opgenomen en dat het niet meer voor verdere evolutie vatbaar zou zijn. Gewoonterecht kan veranderen. Heel de geschiedenis van het ongeschreven monarchierecht toont dat aan. Dit gezegde zijnde, komt het ons, zeker wat België betreft, weinig realistisch voor te denken dat een openbaar debat over de regeringsvorming in de Kamer van Volksvertegenwoordigers, een alternatief zou kunnen zijn voor de huidige procedure. Niet alleen gaat er in dat systeem tijd verloren doordat de Kamer niet meteen, de dag na de verkiezingen, in staat is om het beraad over de regeringsvorming op te starten. Het parlement is ook niet het geschikte forum voor het ontwarren van de politieke knopen en het sluiten van de compromissen die voor de vorming van de regering vereist zijn. De ervaring - of liever de non-ervaring - in Nederland lijkt dit slechts te bevestigen. Wij houden het voorlopig dan ook bij Willem Elsschot: 'Tussen droom en daad, staan wetten in de weg en praktische bezwaren, en ook weemoedigheid die niemand kan verklaren en die des 's avonds komt, wanneer men slapen gaat.' ${ }^{160}$

-40. Een alternatief dat ook wel eens naar voor wordt geschoven is de regeringvorming aan de Kamervoorzitter toe te vertrouwen. ${ }^{\text {I6r }}$ De suggestie stuit eveneens op evidente bezwaren. De Kamervoorzitter is immers een politicus, met sterke partijpolitieke banden. Veelal behoort hij tot de meerderheid. In België maakte de toebedeling van het voorzitterschap van Kamer en Senaat deel uit van de regeringsonderhandelingen. Om de neutraliteit te verwerven die van de regisseur van de crisis mag worden verwacht, zal het voorzitterschap dus wezenlijk moeten evolueren. De Kamervoorzitter zou op andere dan partijpolitieke gronden moeten worden aange-

I58 Parl. St., Kamer, I992-I993, 729/7, p. Io, I7, 20, 25, 30.

I59 Zo werd het voorstel afgewezen om in geval van een crisis, de regering te verplichten haar ontslag pas aan de Koning aan te bieden nadat zij de Kamer daarvan in kennis heeft gesteld. De argumentatie luidde: 'Dit beginsel zou echter de als gewoonterechtelijk beschouwde praktijk volgens welke de Koning door confidentieel overleg tracht regeringscrisissen op te lossen onmogelijk maken ...' (Parl. St., Kamer, I992-I993, 729/7, p. 4, zie ook p. 26, 28, 30 en 3I).

I6o W. Elsschot, Het huwelijk, I9ı。.

I6I In Zweden komt de regeringsvorming toe aan de voorzitter van de Riksdag. Deze raadpleegt vertegenwoordigers van de verschillende partijen en overlegt ook met ondervoorzitter van de Riskdag. Hij doet een voorstel waarover binnen vier dagen wordt gestemd. Indien de helft van de leden het afwijst, is het voorstel verworpen (art. 4). Indien er na vier voorstellen geen enkel voorstel is aanvaard, wordt de Riksdag ontbonden en worden er verkiezingen gehouden (art. 5). Zie Ph. Lauvaux, Parlementarisme rationalisé et stabilité du pouvoir exécutif, Brussel, Bruylant, I988, p. I3I. 
duid. Maar is het redelijk een depolitisering te verwachten precies op het ogenblik dat men aan de Kamervoorzitter de eminent-politieke rol van de regeringsvorming wil toevertrouwen? Zal de twijfel aan zijn neutraliteit niet groter zijn dan de twijfel aan de neutraliteit van het staatshoofd die nu sporadisch wordt geuit? In Denemarken heeft een meerderheid in het parlement reeds tweemaal de Koning aanbevolen de Speaker tot informateur aan te stellen. Telkens werd het een mislukking. De Speaker werd er immers van beschuldigd in het geheim met zijn eigen partij te onderhandelen. Vandaar dat men in Denemarken sindsdien opnieuw ervan overtuigd is dat de koningin, als een politiek neutrale instantie, meer geschikt is om de regeringsvorming tot een goed einde te brengen. ${ }^{162}$

-4I. Ten slotte wordt soms ook geopperd dat er geen regisseur van de regeringvorming nodig is. De ervaring met de vorming van de regeringen van de gemeenschappen en de gewesten, waar geen Koning bij te pas komt, zou dat aantonen. Op grond van artikel 59 van de Bijzondere wet van 8 augustus I980 tot hervorming der instellingen wordt de gemeenschaps- en gewestregering door het Parlement gekozen. Over de regeringsvorming wordt vooraf informeel onderhandeld tussen politieke partijen, met als enige gebruik dat de voorzitter van de partij met de meeste zetels het recht heeft als eerste het initiatief te nemen. In geen van de gemeenschappen en gewesten, ook niet in het tweetalig Brussels Hoofdstedelijke Gewest, heeft dit tot nu toe tot onoverkomelijke problemen geleid. De regeringen werden vrij vlot gevormd. We willen daarbij echter drie kanttekeningen plaatsen. In de eerste plaats is de ervaring met de vorming van gemeenschaps- en gewestregeringen nog veeleer beperkt, aangezien er slechts sinds 1995 rechtstreeks verkozen gemeenschaps- en gewestparlementen bestaan. Vervolgens zal het in het licht van de complexe federale politieke verhoudingen wellicht niet zo eenvoudig zijn om het over elementaire procedureregels voor de regeringsvorming eens te worden. ${ }^{{ }^{63}}$ Men kan bv. wel stellen dat de grootste partij het initiatief neemt, maar welke partij is dat: de partij met de meeste zetels, met het hoogste aantal stemmen, of met het hoogste percentage aan stemmen en berekent men dat per taalgebied of per politieke familie over de taalgrenzen heen? Tenslotte is de vorming van een regering op gemeenschaps- en gewestniveau, qua moeilijkheidsgraad, niet te vergelijken met de vorming van een federale regering. Door de evenredige vertegenwoordiging en de versplintering van het politieke landschap en door de communautaire opsplitsing van de politieke partijen en de verplichte paritaire samenstelling van de ministerraad, zijn er in de praktijk steeds minimaal vier partijen nodig om een regering te vormen. Wil men daarenboven de grondwet of de bijzondere wetten inzake de staatshervorming herzien dan is een tweederde meerderheid nodig, zodat men al gauw met minstens zes partijen rond de tafel zit. Het gegeven dat op het federale niveau met de resultaten

I62 T. Kaarsted, 'Denmark, a limited monarchy', in Parlementaire monarchie, Parliamentary Monarchy, Res Publica, I99I/I, p. 44.

I63 Zie voor de pogingen in Groot-Brittannië om in geval van een 'hung parliament' guidelines te bepalen die de Koningin zou dienen te volgen bij de vorming van de regering. V. Bogdanor, Multi-Party Politics and the Constitution, Cambridge, University Press, I983, 220 p. en D. Butler, Governing Without a Majority, I987, MacMillan, I986, I56 p. 
van twee democratieën - een Vlaamse en een Franstalige - rekening dient te worden gehouden, waarvan de politieke preferenties vaak sterk verschillen, levert steeds meer problemen op. Uit de ervaring van de afgelopen maanden en jaren blijkt dat de regeringsvorming op federaal vlak daardoor echt geen sinecure is.

-42. Is de rol die het staatshoofd speelt bij de regeringvorming nodig? Zou men zonder kunnen? Kan de politieke klasse het best alleen aan? Als buitenstaander komt het ons voor dat zonder regisseur die de voortgang van de regeringsvorming stimuleert, deze nog chaotischer en ondoorzichtiger dreigt te worden en in de achterkamertjes van de politiek dreigt te verzanden. We zijn dan ook geneigd het eens te zijn met K. Rimanque en M. Wouters die in I99I schreven: 'Het ingewikkelde krachtenspel dat een regeringsvorming in dit land beheerst, heeft nood aan een actief, maar boven communautaire en politieke tegenstellingen verheven convergentiepunt. Precies daar ligt de grondwettelijke zending van de koning, die daardoor ook meer inhoudelijke betekenis krijgt dan in de meeste andere parlementaire monarchieën. ${ }^{{ }^{164}} \mathrm{We}$ erkennen echter volmondig dat de politieke klasse uiteindelijk het best geplaatst is om het nut van 's Konings optreden in te schatten.

\section{$2 \quad$ Het ontslag van de regering en de ontbinding van de Kamers}

-43. Volgens de grondwet van I83 beschikte de Koning over nog twee andere prerogatieven om een vastgelopen politieke toestand weer vlot te krijgen: hij kan zijn ministers ontslaan en de Kamers ontbinden. Reeds eerder gaven we aan dat de grondwet in 1993 werd herzien om tot een meer rationele verhouding tussen het parlement en de regering te komen. De nieuwe bepalingen over de legislatuurregering en het legislatuurparlement beperken de mogelijkheden waarover de Koning beschikt wel maar sluiten die zeker niet uit.

\section{A Het ontslag van de regering}

-44. Volgens artikel 96, eerste lid, van de grondwet benoemt de koning niet alleen zijn ministers, hij kan ze ook ontslaan. In onze tijd is de realiteit hier echter dat de Koning niet in staat is een regering ontslag te geven (révocation) die niet bereid is zelf ontslag te nemen (démission). Elke handeling van de Koning - ook zo'n ontslag (révocation) - moet immers gedekt zijn en indien de regering er niet toe bereid is, gebeurt er niets. In de periode voor de Tweede Wereldoorlog, zowel onder Leopold II als Albert I, is het nog wel voorgekomen dat een regeringsleider, op vraag of onder druk van de Koning, ontslag aanbood, ook al was de regering niet intern verdeeld en genoot ze nog het vertrouwen van een meerderheid in het parlement. ${ }^{165}$ Omdat de ministers dan echter niet aarzelden de kroon te ontbloten en over hun ontslag 'tekst en uitleg' gaven aan hun achterban, werd duidelijk dat dit voor de koning een

I64 K. Rimanque en M. Wouters, 'Het optreden van de koning in België, in het bijzonder tijdens regeringscrisissen', o.c., p. I2I.

I65 Zie J. Stengers, De Koningen der Belgen, Van Leopold I tot Albert II, p. 59. 
heilloze weg was. De laatste maal dat een Koning een overigens mislukte poging ondernam om een regering tot ontslag te bewegen was in 1960 , toen Boudewijn I eerste minister $\mathrm{G}$. Eyskens er vergeefs toe aanzette ontslag te nemen. ${ }^{166}$ Een ontslag door de Koning - een 'révocation' zoals artikel 96 van de grondwet het uitdrukt komt nog slechts voor wanneer op voorstel van de eerste minister ontslag wordt gegeven aan individuele ministers die niet langer in de regering gewenst zijn. ${ }^{167}$

-45. De nieuwe bepalingen in de grondwet over de legislatuurregering geven thans uitdrukkelijk aan in welke omstandigheden de Kamer van Volksvertegenwoordigers een regering ten val kan brengen. Op grond van artikel 96, tweede lid, van de grondwet dient zij daartoe hetzij een constructieve motie van wantrouwen aan te nemen, hetzij op een constructieve wijze een motie van vertrouwen te verwerpen. Het volstaat dus niet dat de Kamer een regering naar huis stuurt. Ze moet ook een alternatief klaar hebben. Ze moet een opvolger voor de eerste minister aan de Koning voordragen. Die laatste heeft dan geen andere keuze dan het ontslag van de regering te aanvaarden en de voorgedragen opvolger aan te stellen tot formateur. De regeling is in 1993 in de grondwet opgenomen, maar is in de praktijk nog nooit toegepast. Als een regering valt, is dat veelal niet het gevolg van een stemming in de Kamer, maar wel van interne onenigheid of conflicten tussen de ministers of tussen de partijen van de meerderheid, die de eerste minister ertoe brengen het ontslag van zijn regering aan de Koning aan te bieden. In dat geval kan de Koning een aantal gewoonterechtelijke prerogatieven uitoefenen.

-46. Maar eerst nog dit. In het recente verleden is gebleken dat de Koning soms een poging onderneemt om de val van de regering te voorkomen, zeker wanneer een probleem voorligt dat de politieke sfeer in om het even welke coalitie dreigt te vertroebelen. Zo heeft Albert II tot tweemaal toe zijn gewicht in de schaal geworpen om een regeringscrisis over de kieskring Brussel-Halle-Vilvoorde te vermijden. Een eerste maal gebeurde dat in het voorjaar van 2005. De regering-Verhofstadt mislukte toen in haar poging om in de schoot van de regering een akkoord te bereiken. Nog vooraleer de eerste minister naar de Kamer trok om daarover een mededeling te doen en opnieuw het vertrouwen van de meerderheid te vragen, verspreidde de persdienst van het Paleis een communiqué met volgende boodschap: 'De koning en de eerste minister hebben er de nadruk op gelegd dat in de huidige omstandigheden een politieke crisis inopportuun zou zijn en schade zou toebrengen aan het economisch en sociaal welzijn van de burgers. ${ }^{1168}$ De meerderheid bevestigde inderdaad

I66 Zie J. Stengers, De Koningen der Belgen, Van Leopold I tot Albert II, p. 7I-73.

I67 Ook deze ontslagen worden voorgesteld als het aanvaarden van het ontslag op voorstel van de eerste minister. Zie over het ontslag van FDF-ministers in 1976 en RW-ministers in I977 in de regering-Tindemans II: J. Stengers, De Koningen der Belgen, Van Leopold I tot Albert II, p. 73-74. Zie ook Communiqué 20 april 2008, Op voorstel van de Eerste Minister heeft de Koning het ontslag aanvaard van de Heer Frédéric Laloux uit zijn ambt van Staatssecretaris voor Armoedebestrijding, toegevoegd aan de Minister van Maatschappelijke Integratie, Pensioenen en Grote Steden.

I68 De Morgen, I3 mei 2005. 
het vertrouwen in de regering. De oppositie hekelde scherp dat de eerste minister de Koning had ingezet om zijn regering te redden. ${ }^{169}$ Ook in de pers klonk kritiek. ${ }^{170}$ Hetzelfde scenario, maar ditmaal zonder succes, herhaalde zich in 2010 toen de onderhandelingen over BHV in de schoot van de regering-Leterme eveneens mislukten en VLD-leider Decroo er 'de stekker uit trok'. De eerste minister bood het ontslag van zijn regering aan. De Koning hield het in beraad. In een communiqué van dezelfde dag liet het Paleis opnieuw weten: 'De Koning en de Eerste Minister hebben er de nadruk op gelegd dat, in de huidige omstandigheden, een politieke crisis inopportuun zou zijn en ernstige schade zou toebrengen enerzijds aan het economische en sociaal welzijn van de burgers en anderzijds aan de rol van België op Europees vlak.' Ditmaal mocht het echter niet baten. Beide communiqués waren uiteraard door de eerste minister gedekt. Het procédé geeft desalniettemin goed weer dat de Koning bereid is om naast zijn eerste minister voor het overleven van de regering en de stabiliteit van de instellingen op te komen. Hij komt daardoor onvermijdelijk in het politieke spel terecht.

-47. Wanneer de eerste minister het ontslag van de regering aan de Koning aanbiedt, beschikt deze over enige appreciatieruimte. Hij kan het ontslag aanvaarden. Hij kan het even in beraad houden om te zien of de spanningen in de schoot van de regering niet verdwijnen. Hij kan het ontslag zelfs weigeren wanneer hij van oordeel is dat het geschil dat de ministers verdeelt, geen crisis waard is en de regering nog steeds over een meerderheid in het parlement beschikt. Dit heeft zich in het verleden meermaals voorgedaan. ${ }^{171}$ Het is ook voorgekomen dat de Koning zijn weigering dan verantwoordt in een brief aan de ontslagnemende eerste minister, die met beider

I69 Vlaams Belang-Kamerlid Annemans vroeg zich af: 'Is het democratisch, dat de eerste minister om zijn eigen carrière te redden, nu ook al de koninklijke familie in het spel betrekt, om ook namens haar een mededeling te doen in het Parlement? Ik heb hier de persmededeling waarop ik lees dat om II.34 uur, meer dan twee uur voor we hier samenkwamen, een mededeling plaatsvond van het paleis en van de premier samen. De Koning en de eerste minister hebben de nadruk erop gelegd dat in de huidige omstandigheden een politieke crisis inopportuun zou zijn. Is het logisch, is het normaal en is het nog democratisch, mijnheer de eerste minister, dat $u$ het staatshoofd betrekt bij uw particuliere problemen, terwijl u daarmee alleen maar aan de Koning vraagt $\mathrm{u}$ te redden van de Vlamingen die Brussel-Halle-Vilvoorde willen splitsen (...). U betrekt de Koning, het staatshoofd bij een politiek debat met als uitspraak dat de Vlamingen normale eisen moeten inslikken om u overeind te houden. Is dat nog democratisch? Nee, dat is niet meer democratisch. Dat is een voorstadium van een vorm van despotisme.', Parl. Hand., Kamer, 2004-2005, CRIV 5I, PLEN I36, II mei 2005, p. 26; NV-A Kamerlid De Groote stelde: 'Zelfs nadat U koning Albert lid hebt gemaakt van het VLD-partijbestuur - dat heb ik zo begrepen uit het perscommuniqué - zult u de tegenstellingen tussen Vlaanderen en Wallonië niet wegwerken.', Parl. Hand., Kamer, 2004-2005, CRIV 5I, PLEN I36, I3 mei 2005, p. II.

I70 L. Van der Kelen, Het Laatste Nieuws, 23 april 20I0: 'Ook de Koning werd gisteren een beetje politicus. Hij noemde de crisis "inopportuun" wegens het komende Europese voorzitterschap van ons land en de economische en sociale problemen. Wel, een crisis komt nooit gelegen. Er is altijd wel een reden waarom een staatshoofd vindt dat zijn regering aan de macht moet blijven. Maar het is niet aan de vorst om een morele inschatting te maken van een partijpolitieke beslissing. Daar is Albert II in de fout gegaan op dezelfde manier als prins Filip ooit heeft gedaan.'

I7I Zie J. Stengers, De Koningen der Belgen. Van Leopold I tot Albert II, p. 75. 
instemming ook in de pers wordt bekendgemaakt. ${ }^{172}$ Uiteraard kan de Koning zijn wil niet opleggen. Uiteindelijk moeten zijn ministers bereid zijn hun portefeuilles weer op te nemen. Om de kroon niet te ontbloten zal de Koning veelal zich hiervan vooraf hebben vergewist, zodat de weigering eigenlijk een intrekking van het ontslag verhult.

-48. Al in I83 I werd in de grondwet aan de Koning het recht toegekend de Kamers te ontbinden. In 1993 werd dat recht weliswaar aan strikte voorwaarden onderworpen, maar nog steeds is een handtekening van de Koning vereist om tot ontbinding te kunnen overgaan. Een van de onthullingen in het boek 'Een koning zonder land' van de journalisten Samyn en Buxant is dat de Koning in zijn gesprekken met partijvoorzitters zou hebben laten verstaan, dat hij niet zou toestaan dat er nieuwe verkiezingen komen en dat hij dus nooit zijn handtekening zou plaatsen onder een ontbindingsbesluit. ${ }^{173}$ Aangezien deze passage uit het boek in het communiqué van het Paleis niet als 'niet correct' werd aangeduid, mag men ervan uitgaan dat de Koning zich inderdaad in die zin heeft uitgelaten.

-49. Lange tijd ging men ervan uit dat het recht om de Kamers te ontbinden een prerogatief is dat het staatshoofd soeverein uitoefent en dat hij dus kan weigeren een ontbindingsbesluit te ondertekenen dat de eerste minister hem voorlegt. ${ }^{174}$ Alhoewel de laatste weigering dateert van 1846 en de Koning sindsdien steeds op het verzoek om de Kamers te ontbinden is ingegaan, werd het standpunt dat hij zou kunnen weigeren nog in 1949 door de commissie-Soenens bevestigd, niet alleen in het meerderheids-, maar ook in het minderheidsadvies. ${ }^{175}$ In het licht van de positie van de Koning ten aanzien van een parlementaire regering is dat standpunt inmiddels echter verfijnd. In zijn boek over 'La fonction royale en Belgique', preciseerde

I72 De laatste maal gebeurde dit in 1966 toen koning Boudewijn het ontslag weigerde van de regering-Harmel. Zie V. Dujardin, Pierre Harmel, Le Cri, 2004, p. 403-406.

I73 'Donderdag 7 oktober ontvangt de vorst de voorzitters van de groene partijen en cdH-voorzitter Joëlle Milquet. De koning is in alle staten, gealarmeerd, woedend. "Ik heb hem nog nooit in zo'n toestand gezien", aldus een van de politici die hem die ochtend zag. "Het gesprek was ongelofelijk. Hij heeft me gezworen dat hij nooit zou toestaan dat er nieuwe verkiezingen komen." "Ze moeten maar hun plan trekken", klinkt het als waarschuwing aan de PS en de $\mathrm{N}$-VA die er niet in slagen een akkoord te sluiten. Ze kunnen voor mijn part nog vijf maanden onderhandelen, als ze dat willen, maar ik teken nooit een besluit om naar nieuwe verkiezingen te gaan. Ik zal het niet toelaten! Daar is geen sprake van."' S. Samyn en M. Buxant, Koning zonder land, o.c., p. 68.

I74 Zie daarover J. Velu, La dissolution du parlement, Brussel, Bruylant, I966, p. 77-95.

175 De meerderheid schreef: 'Het recht van ontbinding, dat één der bestanddelen is van het parlementaire stelsel, en dat klaarblijkelijk niet mag uitgeoefend worden dan onder de ministeriële mede ondertekening, laat aan de Koning toe beroep te doen op de soevereine Natie.' De minderheid was nog duidelijker: 'De regel wil dat de Koning zich schikt naar de adviezen zijner ministers (...). In de werking van het parlementair regime, zijn er nochtans twee ogenblikken waarop een beslissing van het staatshoofd zelf waarlijk geëist wordt: de keuze van de formateur die de Eerste Minister zal worden en het uitzonderlijk feit, een door de regering voorgedragen ontbindingsbesluit te ondertekenen of niet.' 
Andre Molitor, met betrekking tot de situatie van voor 1993, dat de Koning inderdaad nog over de mogelijkheid beschikt om zijn handtekening te weigeren althans wanneer het ontbindingsbesluit door een ontslagnemende regering wordt voorgelegd. Het staatshoofd kan dan immers oordelen dat het parlement nog steeds door de vorige verkiezingen is gelegitimeerd en dat er dan ook geen reden is om in te gaan op de vraag van een regering die, bij hypothese, zelf niet meer over het vertrouwen van de volksvertegenwoordiging beschikt. Terecht stelde Molitor echter ook dat het moeilijk is in te denken dat de Koning zou weigeren als het ontbindingsbesluit wordt voorgelegd door een regering die wel nog over de volheid van haar bevoegdheden beschikt en die wel nog de steun van een meerderheid in het parlement geniet. In dat geval zou hij immers zowel met de regering, als met het parlement in conflict treden. De Kroon zou dan zijn ontbloot. ${ }^{176}$

-50. De situatie is inmiddels nog verder gewijzigd. In I993 zijn er, naast de bepalingen over de legislatuurregering, ook bepalingen over het legislatuurparlement in de grondwet opgenomen. Om het parlement toe te laten de hele legislatuur uit te doen, beperken deze bepalingen het ontbindingsrecht van de Koning. Op grond van artikel 46, eerste lid, van de grondwet heeft de Koning enkel nog het recht de Kamer van Volksvertegenwoordigers te ontbinden - met de ontbinding van de Senaat als automatisch gevolg - wanneer de Kamer het vertrouwen in de federale regering heeft opgezegd zonder een opvolger voor de eerste minister voor benoeming aan de Koning voor te dragen. De achterliggende idee is duidelijk: wanneer de Kamer de regering op een louter destructieve wijze ten val brengt, door een niet-constructieve motie van wantrouwen aan te nemen of door een motie van vertrouwen op een niet-constructieve wijze te verwerpen, en daardoor dus duidelijk maakt niet over een alternatief te beschikken, dan kan de Koning de Kamer ontbinden, zodat verkiezingen tot een herverdeling van de politieke kaarten kunnen leiden. Verplicht is de Koning daartoe echter niet. In zo'n situatie dienen er zich verschillende mogelijkheden aan. Eerste minister Dehaene verklaarde in de Kamer: 'Indien de Kamer geen opvolger aanwijst, is de regering niet verplicht haar ontslag in te dienen. Er kan een dialoog tot stand komen, waardoor de regering uiteindelijk misschien toch het vertrouwen krijgt. Bovendien is de Koning er in dat geval niet toe verplicht de Kamer te ontbinden. ${ }^{177}$ De regering kan dus doorgaan en erop rekenen opnieuw de steun te krijgen van haar meerderheid. ${ }^{178}$ Slaagt ze daarin niet dan zal ze uiteindelijk toch haar ontslag moeten aanbieden. Ook dan is de Koning nog niet verplicht te

I76 A. Molitor, La fonction royale en Belgique, p. 45.

I77 Zie Parl. St., Kamer, I992-I993, 729/7, p. 5, 24. Artikel 46, eerste lid, heeft het uitsluitend over het 'recht' van de Koning om de Kamers te ontbinden, en artikel 46, derde lid, bepaalt dat hij de Kamer 'kan' ontbinden.

I78 Zie Parl. St., Kamer, I992-I993, 729/7, p. 3-4. 'De voorgestelde wijzigingen zijn dan ook geenszins een beperking van de mogelijkheid voor de regering om te beoordelen of zij al dan niet het vertrouwen van de Kamer behoudt en voort kan regeren. Een en ander is mogelijk nadat een zogenaamde "gewone" motie van wantrouwen is aangenomen of een zogenaamde gewone vertrouwensmotie (dat wil zeggen zonder dat een opvolger wordt voorgedragen) is verworpen.' 
ontbinden. Hij kan pogen een nieuwe regering te vormen. Slaagt hij daar echter niet in dan is de ontbinding de enige uitweg.

-51. Naast de hypothese dat de crisis door een niet-constructieve stemming in het parlement wordt veroorzaakt, houdt de grondwet ook rekening met het quod plerumque fit, namelijk dat de crisis ontstaat in de schoot van de regering zelf, die vrijwillig haar ontslag aan de koning aanbiedt. ${ }^{179}$ Op grond van artikel 46 , derde lid, van de grondwet kan de Koning ook dan de Kamer van Volksvertegenwoordigers ontbinden, doch uitsluitend 'nadat deze daarmee bij volstrekte meerderheid van haar leden heeft ingestemd.' Ook hier is de achterliggende idee duidelijk: wanneer de crisis niet door de Kamer is uitgelokt, hoeft deze niet het gelag te betalen, tenzij ze er, wegens de uitzichtloosheid van de crisis, zelf mee instemt ontbonden te worden, zodat een deblokkering van de situatie mogelijk wordt. In de grondwet is niet bepaald volgens welke procedure de Kamer haar instemming tot ontbinding geeft. Tijdens de parlementaire voorbereiding werd slechts aangegeven dat de modaliteiten door de Kamer zelf in haar reglement moeten worden vastgesteld. ${ }^{180}$ De Kamer heeft echter nagelaten dat te doen. Het komt ons voor dat er twee mogelijkheden zijn: ofwel de eerste minister legt aan de Kamer de vraag tot ontbinding voor, ${ }^{18 \mathrm{r}}$ ofwel de Kamer spreekt zelf zich op eigen initiatief voor de ontbinding uit. ${ }^{182}$ Van zodra de instemming is gegeven, kan men het zich opnieuw niet meer indenken dat de koning zou weigeren het ontbindingsbesluit te ondertekenen. Hij zou zich dan immers niet alleen tegen de ontslagnemende regering, maar ook tegen de meerderheid in de Kamer keren. De Kroon zou opnieuw zijn ontbloot.

-52. De volgende hypothese is deze waarin België zich thans bevindt. De regering is gevallen tijdens de vorige legislatuur en is sindsdien ontslagnemend, het parlement werd ontbonden en er werden verkiezingen georganiseerd, maar de Koning slaagt er (vooralsnog) niet in een regering te vormen. Tijdens de parlementaire voorbereiding van artikel 46 van de grondwet, verklaarde eerste minister Dehaene hierover '(...) dat wanneer na de verkiezingen geen regeringsformatie mogelijk blijkt, de enige oplossing erin bestaat nieuwe verkiezingen te organiseren. ${ }^{1{ }^{183} 3}$ Uiteraard dient ook in die

I79 De suggestie dat die regering in geval van interne onenigheid verplicht zou zijn voor de Kamer te verschijnen, wel wetende dat zij in dat geval het vertrouwen van de Kamer niet zal krijgen, werd afgewezen (zie Parl. St., Kamer, I992-I993, 729/7, p. 4 en 23). Het heeft ook weinig zin dat de regering het vertrouwen vraagt, indien ze zelf niet wenst door te gaan.

I80 Parl. St., Senaat, I992-I993, nr. I00-39/2, p. 8. Zie ook Parl. St., Kamer, I994-I995, nr. I766/I, p. 43 en 47 .

I8I Een lid ging ervan uit dat de ontslagnemende eerste minister aan de Kamer de instemming met de ontbinding zou vragen, Parl. St., Kamer, I994-I995, nr. I766/I, p. 34 (verslag over het voorstel tot wijziging van artikel 92 van het Reglement).

I82 Zie in die zin reeds A. Alen en J. Clement, 'Legislatuurregering' en 'legislatuurparlement': politieke gadgets of een wezenlijke innovatie', in A. Alen en L.P. Suetens, Het federale België na de vierde staatshervorming. Een commentaar op de Nieuwe grondwet en haar uitvoeringswetten, Die Keure, I993, p. 217: 'Natuurlijk verhindert, bij gebreke van precieze grondwettelijke voorschriften daaromtrent, niets dat, bij een vrijwillig ontslag van de Regering, in een parlementair debat de Kamer zich uitspreekt voor ontbinding, waardoor de keuzemogelijkheden van de Koning de facto wel sterk worden gehypotheceerd.'

I83 Parl. St., Kamer, I992-I993, 729/7, p. 23. 
hypothese de Kamer in te stemmen met de ontbinding. Doet ze dat, bv. na op eigen initiatief daarover een debat te hebben gehouden, dan beschikt de Koning opnieuw niet over de mogelijkheid om te weigeren het ontbindingsbesluit te tekenen.

-53. Er is ten slotte nog een laatste mogelijkheid om de Kamers voortijdig te ontbinden, nl. wanneer de federale wetgevende macht - Koning, Kamer en Senaat met andere woorden - een verklaring tot herziening van de grondwet goedkeurt. Op grond van artikel I95, tweede lid, van de grondwet, zijn beide Kamers, na die verklaring, van rechtswege ontbonden. Het komt ons voor dat de Koning ook bezwaarlijk zal kunnen weigeren zijn medewerking te verlenen aan de verklaring tot herziening die de regering hem ter ondertekening voorlegt, zeker niet indien Kamer en Senaat eenzelfde verklaring willen goedkeuren. ${ }^{84}$

\section{De koning en de regering}

-54. In België worden de machten aan de Koning toegewezen, niet aan de regering of aan de ministers. Die zijn formeel nog steeds slechts de direct verantwoordelijke medewerkers van de Koning. Zeker, de grondwet maakt duidelijk dat zij een cruciale rol spelen. De Koning is immers onschendbaar, de ministers zijn verantwoordelijk (art. $88 \mathrm{GW}$ ) doordat zij de Koninklijke besluiten 'mede ondertekenen'. Zonder die medeondertekening kunnen de 'akten van de Koning' geen gevolg hebben (art. 106 GW). De 'eenheid van de Kroon' is een constitutioneel beginsel. ${ }^{185}$ De Koning en zijn ministers zijn één. Ze dienen elkaar te vinden. Over de wijze waarop dat moet gebeuren, zegt de grondwet echter niets. Op grond van de tekst alleen is het perfect mogelijk dat een autoritaire koning alle beslissingen zelf neemt en de ministers er hun handtekening onderzetten. Ook het omgekeerde scenario, een koning die alles tekent wat zijn ministers hem voorleggen, is mogelijk. Door de opkomst van de parlementaire democratie heeft de Koning uiteraard de centrale plaats in het staatsbestel verloren. In de staatsrechtelijke praktijk maken de ministers de dienst uit. Zij zijn niet langer van de Koning, maar van het parlement en van de politieke partijen afhankelijk. De rol van de Koning is dan ook beperkt.

I84 Zie infra.

I85 'Quand la Constitution dit le Roi, elle entend le Roi et ses ministres dont l'action est indissolublement liée.' L. De Lichtervelde, 'L'Unité du Pouvoir', Bull. cl. lettr. sc. morales et politiques, 5e série, t. XXXVII, I95I, I2/4, p. 508-509. F. Delpérée, 'Le Roi règne et ne gouverne pas', J.T., I990, p. 702. 


\section{De Koninklijke invloed: het recht te worden geraadpleegd, te waarschuwen} en aan te moedigen

De drie R's van Bagehot

-55. Volgens de thans geldende conventies beschikt de Koning ten aanzien van het regeringsbeleid slechts over de drie prerogatieven die in 1867 door de Britse publicist Walter Bagehot kernachtig werden verwoord in zijn vermaarde essay 'The English Constitution': 'the right to be consulted, the right to warn and the right to encourage' (het recht te worden geraadpleegd, het recht om te waarschuwen en het recht om aan te moedigen). En Bagehot voegde eraan toe: 'And a king of great sense and sagacity would want no others.' Volgens Bagehot zou een gesprek tussen de niet-verantwoordelijke koning en zijn verantwoordelijke minister als volgt moeten verlopen: 'The responsibility of these measures is upon you. Whatever you think best must be done. Whatever you think best shall have my full and effectual support - I do not oppose, it is my duty not to oppose; but observe that I warn.' Dat moest volstaan, vond Bagehot. Het kon ook effect hebben. Immers: 'Supposing the king to be right and to have what kings often have, the gift of effectual expression, he could not help moving his minister. He might not always turn his course, but he would always trouble his mind. ${ }^{\text {I86 }}$

-56. De wijze waarop de Koning zijn invloed in de regering doet gelden, is geëvolueerd in de tijd. In het verleden zat hij vaak de ministerraad voor. Onder Koning Boudewijn is dat nog tweemaal voorgekomen: op 3 december I95I met op de agenda een aantal problemen van algemene aard, en een laatste maal op I3 november I957, toen de raad vergaderde over de Inga-stuwdam in Kongo. ${ }^{87}$ De gewoonte doofde uit omdat de deelname van de koning aan de debatten in de ministerraad het risico inhield dat zijn onpartijdigheid zou worden aangetast en dat zijn onschendbaarheid door indiscreties in het gedrang zou komen. Nadat de samenstelling van de ministerraad in 1970 in de grondwet zelf werd opgenomen, ${ }^{188}$ heeft de Koning ook de jure geen zitting meer in de raad. Om niet helemaal buitenspel te staan, ${ }^{189}$ werd in de jaren zestig overeengekomen dat de Koning vooraf de agenda van de ministerraad ontvangt en dat hij ook de documenten die erop betrekking hebben, kan

I86 W. Bagehot, The English Constitution, Collected Works, vol. 5, London, I974, p. 253.

I87 J. Stengers, De koningen der Belgen, p. I39.

I88 Art. 99 GW: 'De Ministerraad telt ten hoogste vijftien leden. De Eerste Minister eventueel uitgezonderd, telt de Ministerraad evenveel Nederlandstalige als Franstalige leden.'

I89 Koning Leopold III had er tegen geprotesteerd dat hij buitenspel werd gezet. In een toespraak in de ministerraad van 2 februari 1939 betreurde hij de praktijk dat beslissingen van de ministerraad aan de pers werden meegedeeld voor er enig overleg met de koning had plaats gevonden. In een brief van 6 maart 1939 aan eerste minister Pierlot schreef hij: 'Het staatshoofd ziet zich genoodzaakt - teneinde de kroon niet te ontbloten - om beslissingen te bekrachtigen, die buiten hem om werden genomen. Indien de beginselen van ons nationaal charter zo verwaarloosd worden, kan het staatshoofd de rol niet meer vervullen die hem toekomt.' Zie J. Velaers en H. Van Goethem, Leopold III. De koning, het land, de oorlog, Lannoo, I994, p. 92. 
opvragen. ${ }^{190}$ Dit zou hem moeten toelaten de punten ter sprake te brengen die hij wenst. Het gaat vooral om een principiële genoegdoening: het korte tijdsbestek laat de vorst veelal nauwelijks toe te reageren. Om zijn invloed uit te oefenen is hij vooral aangewezen op het wekelijkse contact met de eerste minister. Elke maandagmiddag ontvangt de Koning hem in audiëntie. Dat biedt de mogelijkheid om het regeringsbeleid in het algemeen te bespreken en in te gaan op de dossiers die bij de ministerraad hangende zijn. Ook de publieke agenda van de Koning kan dan aan bod komen. Ook met de andere ministers en met politici van de meerderheid en de oppositie zijn er contacten, maar heel wat minder frequent. Dat de Belgische koningen de drie R's inmiddels volkomen hebben 'verinnerlijkt' moge blijken uit de brief die koning Boudewijn op II juli 1988 schreef aan eerste minister Martens in verband met de staatshervorming. Daarin stelde de vorst: 'De bevoegdheden van de Koning, zoals die vastgelegd zijn in de grondwet en de constitutionele gebruiken, bestaan in hoofdzaak uit raadgeving, invloed en waarschuwing. Ik meen dan ook U de adviezen te moeten bevestigen die ik ter zake tijdens de voorbije maanden aan elk van mijn gesprekspartners steeds heb herhaald.' ${ }^{\text {rgr }}$

Het Geheim van Laken

-57. De contacten tussen de koning en zijn ministers dienen vertrouwelijk te verlopen. De koning oefent zijn invloed binnenskamers uit, in private gesprekken of in briefwisseling met zijn ministers. Die oordelen of ze met zijn inzichten al dan niet rekening houden. Om de 'eenheid van de Kroon' te bewaren, treden ze samen naar buiten. Ieders aandeel in de besluitvorming dient onbesproken te blijven. De Kroon mag niet worden ontbloot. ${ }^{192}$ 's Konings opvattingen over een politiek geladen kwestie mogen niet aan de openbaarheid worden prijsgegeven. ${ }^{193}$ Het colloque singulier, de samenspraak tussen de koning en zijn ministers, is gedekt door het 'Geheim van Laken'. ${ }^{194}$ Vanuit historisch oogpunt is dit de prijs die is betaald om koninklijke macht in te ruilen voor koninklijke invloed. Ook ter wille van de onschendbaarheid van de Koning en de verantwoordelijkheid van de ministers is die vertrouwelijkheid noodzakelijk. Door het aandeel van de Koning in de besluitvorming te onthullen, komt hij op het politieke voorplan terecht. Hij kan omstreden raken en voorwerp van een polemiek worden. ${ }^{195}$ Omgekeerd kunnen de verantwoordelijke ministers

I90 A. Molitor, La fonction royale, p. I3I. J. Stengers, De koningen der Belgen, p. I45.

I9I W. Martens, De Memoires, 'Luctor et emergo', o.c., p. 823.

I92 F. Delpérée en B. Dupret, 'Nul ne peut découvrir la couronne’, p. I4-I5. “Découvrir la Couronne”, c'est compromettre le Roi. C'est laisser croire que le Roi agit sans les ministres, ou que les ministres décident sans le Roi. C'est fractionner le pouvoir exécutif qui, au sens de l'article 64 de la Constitution a vocation à s'exprimer d'une seule voix. C'est instaurer le divorce entre le Roi et les membres du gouvernement qu'il désigne, alors que ceux-ci sont, aux termes de l'article 64 de la Constitution, responsables des actes et des attitudes du pouvoir exécutif.'

I93 Cf. F. Delpérée en B. Dupret, 'Nul ne peut découvrir la couronne', p. I4, I5 en 23.

I94 P. De Visscher, 'La Fonction royale', 683; D. Ryelandt, 'La fonction royale', p. 22.

I95 Zie de Lichtervelde, 'Les coutumes de la monarchie constitutionnelle', o.c., p. I6I-I62; A. Van Welkenhuyzen, $V^{\circ}$ Chef de l'état, R.P.D.B., I977, Compl. V., nr. 55; R. Ergec, 'L'institution monarchique à l'épreuve de la crise', p. 265. 
zich dan achter de Koning verschuilen. Artikel Io2 van de grondwet bepaalt: 'In geen geval kan een mondeling of schriftelijk bevel van de Koning een minister van zijn verantwoordelijkheid ontheffen.' Ook aanbevelingen, adviezen, suggesties of wensen van de Koning mogen door de minister niet worden ingeroepen. Meningsverschillen dienen eveneens binnenskamers te blijven. De vertrouwelijkheid van de contacten tussen de Koning en zijn ministers, is onontbeerlijk voor de goede werking van monarchie en democratie. Enerzijds kan de Koning daardoor vrij met zijn ministers spreken en ten volle zijn prerogatief uitoefenen om 'aan te moedigen en te waarschuwen' zonder in de partijstrijd terecht te komen, ${ }^{196}$ doch anderzijds blijft de volle verantwoordelijkheid bij de ministers, die alleen op eigen gezag argumenten kunnen aanvoeren als ze voor de Kamers hun beleid verantwoorden.

-58. Het 'Geheim van Laken' geldt in de eerste instantie voor de gesprekken die de Koning met zijn ministers en staatssecretarissen voert. Voor hen vloeit het rechtstreeks voort uit de artikelen 88 en ro6 van de grondwet. ${ }^{197}$ Ook parlementsleden mogen hen daarover niet aan de tand voelen. Doen ze het toch, dan zal de Kamer- of Senaatsvoorzitter hen tot de orde roepen. ${ }^{198}$ Ook de Raad van State wijst elke poging af om de vertrouwelijkheid van het kroonberaad te doorbreken. Stukken waaruit blijkt op welke wijze een koninklijk besluit in gemeen overleg tussen het staatshoofd en de verantwoordelijke minister is tot stand gekomen, bv. op welke datum een stuk door de koning werd ondertekend en door de minister mede ondertekend, wat van belang kan zijn voor een termijnberekening, worden steevast uit de debatten geweerd. ${ }^{\text {I99 }}$

-59. Het is een conventie dat ook parlementsleden de vertrouwelijkheid van hun politieke contacten met het staatshoofd bewaren. Indien zij in Kamer of Senaat de persoonlijke opinies van de Koning ter sprake brengen, zal de voorzitter hen daarvoor tot de orde roepen. ${ }^{200}$ Weliswaar geldt voor hen de ministeriële verantwoordelijkheid niet. Doordat zij echter de eed op de grondwet hebben afgelegd, dienen ook zij de onschendbaarheid van het staatshoofd te eerbiedigen. Ook van andere gesprekspartners van de koning wordt verwacht dat zij hun gedachtewisselingen met de Koning over politieke aangelegenheden voor zich houden. Molitor heeft het over een traditie en zelfs over een 'ongeschreven regel'. ${ }^{201}$ Meer dan een 'gentlemen's

I96 F. Delpérée en B. Dupret, 'Nul ne peut découvrir la couronne', nr. 42.

I97 In die zin eerste minister Martens in zijn antwoord op een parlementaire vraag van de $h$. Courtois over het boek van journalist H. De Ridder over de regeringsvorming van ig88, Parl. Hand. I2 oktober 1989 , p. 30 en v.

I98 F. Delpérée en B. Dupret, 'Nul ne peut découvrir la couronne', nr. 44.

I99 R.v.St. I9 december I95I, Michielsen t. B.S., nr. I222; R.v.St. I9 mei I959, Meulemeester t. B.S., nr. 7082; R.v.St. 24 mei I960, Vandendries t. B.S., nr. 7888; R.v.St. 26 april I99I, Dehove, nr. 36.884 .

200 A. Mast, Overzicht van het Belgisch grondwettelijk recht, nr. 243, p. 230-23I; A. Van Welkenhuyzen, $V^{\circ}$ Chef de l'état, R.P.D.B., I977, Compl. V., nr. 56.

201 A. Molitor, La fonction royale en Belgique, p. Ioo. Eerste minister Martens verwees hiernaar in zijn antwoord op een parlementaire vraag van de h. Courtois over het boek van journalist H. De Ridder over de regeringsvorming van I988. Parl. Hand. I2 oktober I989, p. 30 en v. 
agreement' dat ze sluiten door de uitnodiging voor een audiëntie te aanvaarden, is het o.i. echter niet. Afdwingbaarheid is niet gewaarborgd. De Koning is aangewezen op het fatsoen van zijn gesprekspartner. Wie de vertrouwelijkheid schendt, hoeft niet te rekenen op een volgende uitnodiging. Maar het kwaad is dan wel geschied. Behoedzaamheid is dus steeds geboden. Ook in privégesprekken dient de Koning ervoor beducht te zijn niet zelf de Kroon te ontbloten, door politieke uitspraken te doen die de regering in verlegenheid kunnen brengen. Hij mag er dan ook niet zonder meer $^{202}$ van uitgaan dat zijn gesprekspartners de vertrouwelijkheidsregel kennen en bereid zijn die ook na te leven. ${ }^{203}$

-6o. Het Geheim van Laken wordt niet steeds nageleefd. Er zijn lekken. Vooral in de periodes van regeringsvorming. We hadden het er al over. Noodgedwongen spreekt de koning dan met vele politici. Niet allemaal zijn ze bereid de conventies na te leven. Vooral partijvoorzitters zijn al eens loslippig. In normale tijden zijn er vooral contacten met de eerste minister en in mindere mate met de vakministers. Die houden de constitutionele deontologie meer in acht. Maar ook niet altijd. Ophefmakend was dan ook het bekendraken in het Nederlandse weekblad Elsevier van de brief die Koning Boudewijn in I99o zond aan eerste minister Martens over een Belgische militaire aanwezigheid in Rwanda. ${ }^{204}$ De eerste minister reageerde vlijmscherp en dreigde ermee dat hij het ontslag zou eisen van de minister die de brief had gelekt. De identiteit van de betrokkene werd nooit achterhaald. ${ }^{205}$ Niet alleen door bewuste lekken, maar ook door een onoplettendheid voor microfoons in de buurt, kunnen gesprekken van de Koning met een minister bekend raken. ${ }^{206}$

\section{De invloed van de Koning: 'Wahrheit und Dichtung'}

-6r. Door het 'Geheim van Laken' is het onmogelijk om te achterhalen hoe vaak de Koning pogingen onderneemt om te wegen op de besluitvorming, hoe vaak hij zijn

202 Het Paleis zou best de gasten van de Koning formeel over de vertrouwelijkheidsregel inlichten en van hen ter zake toezeggingen bekomen.

203 Een incident zoals met de Nederlandse koningin die in een gesprek met de Amerikaanse politicus Jesse Jackson liet verstaan dat zij, anders dan haar regering, voor uitstel van plaatsing van de middellange afstandsraketten was, wat deze prompt aan de pers meldde, is de Belgische koning nog niet overkomen. Zie H. van Wijnen, De macht van de Kroon, Uitgeverij Balans, 2000, p. 33 .

204 Zie Parl. Hand., Kamer, 29 oktober I990, p. II 2 en Parl. Hand., Senaat, 25 oktober I990, p. 53. Zie daarover W. Martens, De Memoires. 'Luctor et emergo', Lannoo, 2006, p. 517-536. G. Polspoel en P. Van den Driessche, Koning en onderkoning. Over de invloed van het Hof en de macht van Jacques van Yperseele de Strihou, o.c., p. 266-268 en P. Rasking e.a., 'De Kroongetuigen', De Standaard, 7 juli r 998.

205 J. Stengers, 'Evolution historique de la royauté en Belgique: modèle ou imitation de l'évolution européenne', Res Publica, I99I/I, 97.

206 Zie bv. Parl. Hand., Kamer, 2003-2004, CRIV 5I Com 345, 29 september 2004 i.v.m. een overigens weinigzeggend gesprek tussen Albert I en minister van Buitenlandse Zaken De Gucht i.v.m. de Congo-politiek. De Gucht verklaarde in de Kamer: 'Ik vind dat de Koning het recht heeft om zijn mening over een dossier te geven. Meestal gebeurt dat en colloque singulier. De pers heeft daar iets van opgevangen. Ik vind dat geen probleem. Het parlement en de regering leggen immers de Afrika-politiek vast. Ik vind dat de Koning absoluut het recht heeft daarover zijn mening te geven, wat hij overigens op een zeer bescheiden manier heeft gedaan.' 
ministers weet te overtuigen en hoe vaak hij daar niet in slaagt. Wat $\mathrm{H}$. van Wijnen over de Nederlandse Koningin schreef, geldt ook voor de Koning der Belgen: 'Hij kan de hand van de minister leiden of de minister tot gedachten inspireren waar deze zelf nooit op gekomen zou zijn. Hij kan iets van de minister gedaan krijgen wat deze niet uit zichzelf zou hebben prijsgegeven. Maar wat hij ook doet, het blijft onbesproken omdat het volgens de leer onbespreekbaar is. ${ }^{\prime 207}$ Op grond van geanonimiseerde gesprekken die ze met politici voerden, trachten journalisten wel een tip van de sluier te lichten. Zo onthullen ze dat, net als koning Boudewijn, ook de huidige koning Albert $\mathrm{II}^{208}$ wel degelijk zijn prerogatieven uitoefent, zij het met een eigen stijl en intensiteit. ${ }^{209}$ Wat ze vermelden, is vaak niet van die aard om te weten 'hoe de vork precies in de steel zit'.

-62. Het komt ons voor dat men de resultaten van de koninklijke invloed op het beleid best niet overschat. De complexiteit van het politiek bedrijf, met coalitieregeringen van vier of meer partijen die een compromis moeten bereiken en daarbij, in deze tijden van multilevel governance, rekening moeten houden zowel met de internationale en Europese rechtsorde, als met de bevoegdheden van de gemeenschappen en de gewesten, laat daar nog weinig ruimte voor. De gewezen hoofdredacteur van

207 H. van Wijnen, De macht van de Kroon, Uitgeverij Balans, 2000, p. 20.

208 Zo bv. L. Neuckermans en P. Van den Driessche, Albert Koning na Boudewijn, Leuven, Van Halewijck, I995, p. 52: 'Tijdens gesprekken met ministers, fractieleiders en partijvoorzitters legt Albert, net als zijn overleden broer, dikwijls de nadruk op morele problemen. Hij dringt daarbij geregeld aan op initiatieven rond maatschappelijke knelpunten zoals prostitutie, euthanasie of kindermishandeling. Zo werd nog vlak voor de ontbinding van de kamers in april 1995 in ijltempo een wet over kinderpornografie en -prostitutie door Kamer en Senaat gesluisd op uitdrukkelijk verzoek van de koning.' G. Polspoel en P. Van den Driessche, Koning en onderkoning. Over de invloed van het Hof en de macht van Jacques van Yperseele de Strihou, Van Halewyck, 200I, p. I24: 'Zo heeft het Paleis bezwaren geopperd tegen het ritssysteem bij verkiezingen. Dat systeem bepaalt dat de kandidatenlijsten seksegemengd moeten worden opgesteld waardoor meer vrouwen worden verkozen. In feite vond van Yperseele dat dit absouut niet hoefde maar hij verbloemde zijn afkeuring achter een resem juridische opmerkingen.' S. Samyn en M. Buxant, Koning zonder land. o.c., p. I7-I8: 'De Koning is traditioneel bekommerd om het imago van zijn land in het buitenland. Het paleis besteedt dan ook bijzondere aandacht aan de departementen Buitenlandse Zaken en Defensie. "Hij pakt dat vrij handig aan", aldus een minister uit de regering-Leterme. "Er zijn geen rechtstreekse tussenkomsten, het zijn eerder wensen die geuit worden"'. Of het nu gaat over de benoeming van sleutelfiguren in het leger of over die van diplomaten op belangrijke posten, de regering en het paleis zijn in permanente dialoog. Albert heeft bijvoorbeeld de bocht ondersteund die Pieter De Crem inzette toen hij in maart 2008 minister van Defensie werd. Het Paleis was zeer verheugd over de pro-atlantische koers van de regering en dat België weer beter lag binnen de NAVO. De Koning steunt ook de buitenlandse operaties in Afghanistan. Enkele jaren eerder toonde hij zich evenwel een hevig tegenstander van de oorlog die onder leiding van de VS en Engeland werd gevoerd in Irak. Hij benaderde persoonlijk verschillende regeringsleden, waaronder toenmalig minister van Buitenlandse Zaken Louis Michel (MR), defensieminister André Flahaut (PS) en premier Guy Verhofstadt (Open VLD) om hen aan te moedigen geen troepen naar Irak te sturen.'

209 In een recent boek lezen we daarover: 'Boudewijn was een sterke figuur die tijdens zijn decennia op de troon niet aarzelde zelf initiatieven te nemen, veto's te stellen tegen de benoeming van bepaalde ministers, regeringsleden de levieten te lezen en actief tussenbeide te komen. Zijn opvolger hanteert een volledig andere stijl. Minder stijf en veel minder sturend. Dat wordt duidelijk op prijs gesteld in de Wetstraat. Albert kan dan ook in de politieke wereld op heel wat krediet rekenen. 'Hij weet dat het beter is als hij ons zoveel mogelijk met rust laat', aldus een vicepremier. S. Samyn en M. Buxant, Koning zonder land, p. I7. 
De Standaard werd samen met zijn collega Béatrice Delvaux van Le Soir door de Koning in audiëntie ontvangen. Hij verklaarde daarover: 'Ik denk niet dat ik de kroon al te zeer ontbloot als ik zeg dat Albert ons daar verteld heeft dat zijn rol nu al goeddeels protocollair is. ${ }^{210}$

-63. P.Y. Monette, een gewezen medewerker van het kabinet van de Koning, schrijft dat het staatshoofd zich wel nog steeds opwerpt als de behoeder van de formele legitimiteit en de legistieke kwaliteit van de teksten die aan zijn ondertekening worden onderworpen. ${ }^{21 \mathrm{II}}$ Een medewerker op het kabinet is er, naar verluidt, voltijds mee belast na te gaan of de wetsontwerpen en ontwerpen van koninklijk besluit die aan de Koning ter ondertekening worden voorgelegd, beantwoorden aan de regels van de behoorlijke legistiek, of de wetteksten die de Koning moet bekrachtigen wel degelijk door het parlement zijn goedgekeurd en of Kamer en Senaat met dezelfde tekst hebben ingestemd. Soms zou de Koning ook op raadpleging van de Raad van State, afdeling Wetgeving, aansturen, wanneer de regering of het parlement dat niet spontaan zelf doet. Wanneer de adviezen van de Raad van State niet worden gevolgd en dit tot juridische ketterijen en inbreuken op fundamentele rechtsregels leidt, durft de Koning er ook op aan te dringen de tekst alsnog te wijzigen. Ten slotte waakt de Koning er ook over dat een ontslagnemende regering zich uitsluitend met de zogenoemde lopende zaken bezighoudt. Daarop gaan we later nader in.

De archieven van het Paleis

-64. Slechts nadat de archieven van het Paleis en van de betrokken ministers openbaar worden kunnen historici pogen de waarheid te achterhalen over de invloed van de Koning op de politieke besluitvorming. Daarover kort dit. Het archief van de Koning en van zijn diensten en medewerkers is een privaat archief dat eigendom is van de Kroon. Op basis van een overeenkomst met het Paleis wordt het beheerd door een afdeling van het Rijksarchief. ${ }^{212}$ De archiefwet van 24 juni 1955 en dus ook de regel van de raadpleegbaarheid na dertig jaar geldt niet. ${ }^{213}$ Zo zijn momenteel alleen de archieven tot en met de abdicatie van koning Leopold III (I7 juli I95I) raadpleegbaar. Het Paleis gaat uit van de beginselen inzake de 'eenheid van de Kroon', de

210 'Wie onder de indruk is van de macht van Albert, stelt zelf niet veel voor', Humo, 7-I3 september 2007.

2 II P.-Y. Monette, Métier de Roi. Famille. Entourage. Pouvoir de A à Z., Brussel, 2002, p. I78.

2 I2 G. Janssens, 'Bewaring en toegankelijkheid in het Archief van het Koninklijk Paleis te Brussel', in Bibliotheek- en Archiefgids, 7I (I995), p. IIo-II7. A. Molitor, La Fonction royale en Belgique, p. 179. Zie ook het antwoord van eerste minister Verhofstadt op de vraag van de h. Geert Lambert over 'het beheer van het archief van koning Boudewijn', meer bepaald over diens 'schriftjes'. 'Wij weten allemaal dat koning Boudewijn in de naoorlogse periode een cruciale rol heeft gespeeld. Ongetwijfeld zullen zijn aantekeningen een belangrijk inzicht verschaffen in de geschiedenis van ons land. Tegelijkertijd moeten wij echter ook respect hebben voor de wil van de koning en van de koningin ter zake, temeer daar het aantekeningen van persoonlijke aard zijn, die wellicht ook een belangrijke, emotionele waarde hebben voor de koningin. De beslissing over het al dan niet overdragen van de documenten aan het koninklijk archief komt bijgevolg aan de koningin toe.' Parl. St., Kamer, 2006-2007, CRIV 5I PLEN 245, 30 november 2006, p. II-I2.

2I3 Artikel I Archiefwet 24 juni I955, zoals gewijzigd bij wet van 6 mei 2009. 
onschendbaarheid van het staatshoofd, de ministeriële verantwoordelijkheid en de vertrouwelijkheid van de contacten tussen de Koning en zijn ministers ('het Geheim van Laken'). Die worden daarenboven erg strikt geïnterpreteerd. Men gaat immers uit van het ook in Nederland verdedigde standpunt ${ }^{214}$ dat ' $z o$ lang politieke actoren die in contact zijn of waren met het staatshoofd in leven zijn, er geen toegang is tot het archief van het huidige of een vorig staatshoofd.' Vandaar dat bv. voor de in 1993 overleden koning Boudewijn 'zowel de ministers die bij hem de eed hebben afgelegd, als zijn kabinetschefs overleden zouden moeten zijn vooraleer de archieven raadpleegbaar kunnen worden.'215 De gewezen ministers zelf hanteren overigens minder strikte regels. Zo publiceerde gewezen eerste minister Martens in zijn De Memoires. Luctor et emergo, een brief die Koning Boudewijn hem op II juli Ig88 overhandigde en waarin hij zijn bezorgdheid uitsprak over een aantal stappen die de regering in de staatshervorming wenste te zetten. ${ }^{216}$

-65. Van de hiervoor vermelde strikte regel wordt soms afgeweken, bv. ten behoeve van parlementaire onderzoekscommissies. Zo kon de zogenoemde Lumumbacommissie van de Kamer van volksvertegenwoordigers de rol van Koning Boudewijn en zijn entourage in de Congo-crisis onderzoeken, onder meer aan de hand van archiefstukken die berusten in het Paleis. ${ }^{217}$ Die commissie stelde toen overigens vast 'dat er op bepaalde terreinen van de Congo-politiek onenigheid bestond tussen het staatshoofd en de regering. Deze onenigheid heeft er in bepaalde gevallen toe geleid dat het staatshoofd eigen handelingen heeft gesteld (actes autonomes).'

Bovendien heeft de commissie vastgesteld dat het staatshoofd belangrijke informatie heeft verkregen, en daar waarschijnlijk de regering niet over heeft ingelicht. In haar aanbevelingen herinnerde de commissie aan 'de grondwettelijke bepalingen en gewoonten betreffende de rol van het staatshoofd. Iedere handeling van het staatshoofd die een directe of indirecte politieke invloed kan hebben moet worden gedekt door een minister. Derhalve mogen publieke tussenkomsten of initiatieven niet tegen die van de regering inzake binnenlandse of buitenlandse politiek ingaan. ${ }^{218}$

-66. Voor critici is het 'Geheim van Laken' het ultieme argument tegen de monarchie. Ze hebben het over een occulte invloed die het daglicht niet verdraagt en die dan ook niet past in de democratie die een 'glazen huis' dient te zijn. Ze vinden het

2I4 Zie voor de verschillende standpunten en de kritiek daarop H. Veenendael, 'Piketpaaltjes op een drassige ondergrond. Het relatieve karakter van de absolute uitzonderingsgrond "eenheid van de kroon"', in M. Bruggeman e.a., Openbaarheid in historisch en hedendaags perspectief, Jaarboek, 2006, Stichting Archiefpublicaties, 's-Gravenhage, 2008, p. 66-79.

2 I5 G. Janssens, Monarchie en buitenlands beleid. Bronnen voor de geschiedenis van de Belgische buitenlandse politiek (I83I-I95I) bewaard in het Archief van het Koninklijk Paleis.

216 W. Martens, De Memoires. 'Luctor et emergo', Lannoo, 2006, p. 823.

217 Zie Parl. St., Kamer, 200I-2002, 0312/006, p. 454-50I. Zie daarover L. De Vos, Ph. Raxhon, E. Gerard en J. Gérard-Libois, Lumumba. De complotten? De moord, Leuven, 2004.

2I8 Zie Parl. St., Kamer, 200I-2002, 0312/006, p. 840. 
ongepast dat er zich in het hart van het systeem een 'zwarte doos' bevindt waarin de controle van de volksvertegenwoordiging niet kan doordringen. ${ }^{219}$ Die kritiek lijkt ons overtrokken. In de democratie verloopt niet alles in het openbaar. Zo vergadert de ministerraad met gesloten deuren. ${ }^{220}$ De compromissen die er gesloten worden, onttrekken zich aan de openbaarheid. Onvermijdelijk ondergaan ministers invloeden allerhande. Ze spreken met partijgenoten, met medestanders in 'bevriende organisaties', met logebroeders of andere geestesgenoten. Ze ondervinden druk van media, van drukkingsgroepen en lobbyisten, zien dagelijks familieleden en vrienden die hen ook wel eens aan de mouw zullen trekken. De democratie zou er slecht voorstaan als dit alles problematisch was. Maar dat is het niet. Het is des mensen. Het is onvermijdelijk. Er is niets mis mee. Uiteindelijk zal de minister zich een overtuiging vormen, een beslissing nemen en daarover desgevallend verantwoording afleggen in de Kamer.

-67. In die zin hoeft ook het recht van Koning 'om te worden geraadpleegd, om aan te moedigen en te waarschuwen' vanuit democratisch oogpunt niet problematisch te zijn. Het staatshoofd bevindt zich in het centrum van het politiek bedrijf. Hij is vaak goed geïnformeerd. Naarmate hij langer op de troon zit, kan hij over een ruime ervaring beschikken. ${ }^{22 I}$ Waarom zou hij die niet ter beschikking kunnen stellen van zijn ministers? In een moeilijk bestuurbaar land als België kan hij zich verdienstelijk maken. Hij kan misschien een waardevol klankbord zijn met wie de premier onbevangen van gedachten kan wisselen. ${ }^{222} \mathrm{Hij}$ kan misschien oplossingen ontwaren die anderen niet zien, omdat ze te zeer betrokken partij zijn en te weinig afstand nemen. Hij kan misschien ook verzoenend optreden tussen de partijen. Vooral de matigende rol is de constitutionele vorst op het lijf geschreven. Een voorwaarde om daarin te slagen is wel dat hij zich onafhankelijk en ongebonden opstelt, boven elke partij of pressiegroep. Alleen vanuit die positie kan hij overtuigen. ${ }^{223}$ Een andere voorwaarde is uiteraard dat hij niet poogt buiten zijn ministers om een parallelle politiek te voeren. Uiteindelijk zal het aan de ministers toekomen zich scherp af te vragen of zij voor hun rekening kunnen nemen wat de Koning hun aanbeveelt. In zijn artikel over 'republikeinse denkfouten' schreef Lunshof scherpzinnig: 'In feite verkeert de koningin in geen meer bevoorrechte positie dan de partner van een minister die elk weekeinde ook haar of zijn invloed kan uitoefenen - en dat soms

2 I9 H. Van den Berg, 'Ratio versus sentiment', in T. Roodewijn (red.), De Republiek der Nederlanden. Pleidooien voor het afschaffen van de monarchie, Amsterdam, De Bezige Bij, I998, p. 24.

220 Het 'geheim van de beraadslagingen van de federale regering' is uitdrukkelijk uitgesloten van de openbaarheid van bestuur. Art. 6, § 2, $3^{\circ}$, wet II april 1994 betreffende de openbaarheid van bestuur.

22I Zo getuigde Wilfried Martens : 'Par sa connaissance personnelle unique des principaux acteurs de la vie publique, le Roi devient la mémoire politique du pays. En ce sens, il exerce une influence', La Libre Belgique, 7 september 1995 .

222 Zie in die zin minister-president W. Kok over zijn contacten met koningin Beatrix. In C. Huysen, Beatrix de Kroon op de Republiek, Uitgeverij Balans, 2005, p. I66-I67.

223 K. Rimanque en M. Wouters, 'Het optreden van de koning in België, in het bijzonder tijdens regeringscrisissen', o.c., p. I05: 'Die invloed zal zelfs aanzienlijk zijn, indien hij het gezag van een onafhankelijke en onpartijdige positie kan koppelen aan de politieke ervaring die voortvloeit uit de lange duur van zijn koningschap en een prestige ontleend aan een toegewijde ambtsvervulling.' 
heel nadrukkelijk doet. Ministers hebben ook vrienden naar wie ze luisteren, zonder dat iemand weet wie dat zijn. Geheimzinnige machten? Zwarte dozen? In het geheel niet, want de minister blijft zelf verantwoordelijk voor wat hij met al die adviezen doet. Dan doet het er niet toe dat partners of goede vrienden zelfverkozen zijn en dat het staatshoofd voor ministers een gegeven is. ${ }^{1224}$

\section{Het recht de handtekening te weigeren: de juridische versus de reële grondwet}

-68. Maar is de constitutionele positie van de Koning echt slechts die van een partner of een vriend die iets influistert? Kunnen de ministers zijn 'aanmoedigingen en waarschuwingen' zomaar naast zich neerleggen? Ze hebben toch ook zijn handtekening nodig? Kan de Koning die dan niet weigeren? Eenvoudige vragen, in het licht van de staatsrechtelijke praktijk, iets moeilijker in het licht van de staatsrechtelijke theorie. De staatsrechtelijke praktijk is duidelijk. Het staatshoofd is er zich van bewust dat eens de politieke besluitvorming is voltooid, hij zijn handtekening niet kan weigeren. Bagehot's adagium is ten volle verinnerlijkt. ${ }^{225}$ Ook de ministers zelf gaan ervan uit dat het om een 'gebonden bevoegdheid' gaat. De Koning kan wel aandringen, hij kan ook wel voor vertraging zorgen, door te talmen met de ondertekening en dat kan soms problematisch zijn. Maar uiteindelijk zal hij zich erbij moeten neerleggen. Hij heeft geen stok achter de deur. Bagehot drukte het met een ander bon mot als volgt uit: 'She must sign her own death-warrant if the two Houses unanimously send it up to her. ${ }^{226}$ A la limite beschikt de Koning dus inderdaad slechts over een adviesrecht. Maar is dat ook de staatsrechtelijke theorie? Reiken zijn constitutionele mogelijkheden niet verder? De Koning moet immers zijn handtekening plaatsen. Daar komt de partner van de eerste minister niet aan toe. Het belang daarvan werd in 1863 door Leopold I sterk in het licht gesteld: 'Niets is essentiëler voor een grondwettelijk soeverein dan het handtekenrecht te behouden, zodat er in het land dat hij regeert niets uitgevaardigd kan worden en er geen benoeming kan gebeuren zonder zijn handtekening; dat is wellicht een zware taak die hij zich oplegt, maar ze is noodzakelijk opdat men niet zou vergeten dat de soeverein altijd de hoeksteen blijft van het maatschappelijk bouwwerk.'227

-69. De commissie-Soenens die in 1949 ermee belast werd een advies uit te brengen over de prerogatieven van de Koning, heeft zich gebogen over de vraag of de Koning inderdaad zijn handtekening kan weigeren. Ze was hierover verdeeld. De meerderheid stelde: 'In het merendeel van de gevallen, zo luidt het, schikt de Koning zich

224 K. Lunshof, 'Republikeinse denkfouten. De monarchie als ware democratie', R. Meijer en H.J. Schoo (red.), De Monarchie. Staatsrecht, volksgunst en het Huis van Oranje, Amsterdam, Prometheus, 2002, p. 260.

225 Op de zgn. 'minikoningskwestie' - de weigering van koning Boudewijn om de abortuswet te ondertekenen - gaan we later in omdat dit van een andere orde was. Het ging er immers niet om dat de koning een vetorecht wilde uitoefenen. Zie infra nr. 80.

226 W. Bagehot, The English Constitution, p. 33.

227 J. Stengers, De koningen der Belgen, p. I39. 
naar het advies van zijn regering. (...) Zo de ministers de Koning er niet toe kunnen bewegen hun opvatting te delen, zullen zij - in algemene regel, na de aandacht van de Koning gevestigd te hebben op de ernst van de toestand en op gevaren die ermede gepaard gaan - geen andere uitweg hebben dan hun ontslag in te dienen, maar de Kamers zullen, hetzij voor, hetzij na de ontbinding, altijd het laatste woord hebben en, in de logische gedachtegang van artikel $25^{228}$ van de grondwet, zal het de plicht van de Koning en van de regering zijn, derwijze te handelen dat de wil van het parlement in de feiten tot uiting komt.' De socialistische minderheid in de commissie was het met deze zienswijze niet eens. Zij argumenteerde dat 'de regel wil dat de Koning zich schikt naar de adviezen zijner ministers en, tenslotte, naar de beraadslaagde beslissingen van zijn regering die haar gezag van de Kamers houdt en die voor deze verantwoordelijk is.' Terwijl de meerderheid nog ruimte liet voor de Koning om in uitzonderlijke omstandigheden ${ }^{229}$ zijn handtekening te weigeren, met als motief dat de beslissing die de regering wilde doordrukken inging tegen de wil van het parlement en zelfs tegen de wil van de bevolking, wat na verkiezingen zou kunnen blijken, was de minderheid van oordeel dat de Koning niet over die ruimte beschikte en dat indien hij er niet in slaagde zijn ministers te overtuigen, hij zich diende neer te leggen en zijn handtekening te plaatsen. Uiteindelijk liggen beide visies dicht bij elkaar. De Koning die zijn handtekening weigert, schendt volgens de minderheid de grondwet, terwijl hij volgens de meerderheid dat niet doet maar wel een ernstige politieke crisis veroorzaakt, die uiteindelijk in een constitutionele crisis kan uitmonden. De Koning moet immers niet alleen bereid zijn de regering te trotseren, die ontslag zal moeten nemen, maar ook het parlement, dat hij desgevallend zal dienen te ontbinden. ${ }^{23}$ Wanneer de kiezers de halsstarrige Koning niet volgen zal een constitutionele crisis dreigen die hem uiteindelijk tot troonsafstand kan nopen.

-70. Het antwoord dat de meerderheid gaf, wordt tot op heden als de huidige stand van het Belgisch constitutioneel recht beschouwd. ${ }^{23 \mathrm{I}}$ Het blijkt trouwens ook nog

228 Thans artikel 33 GW: 'Alle machten gaan uit van de Natie. Zij worden uitgeoefend op de wijze bij de Grondwet bepaald.'

229 In die zin het commentaar van commissielid P. De Visscher, 'La Fonction royale', Rev. Gen. B., I949, p. 685 .

230 Sinds de herziening van de grondwet zijn de mogelijkheden tot ontbinding sterk beperkt. Zie infra nr. 48.

23I Zie bv. F. Delpérée en B. Dupret, Nul ne peut découvrir la couronne, 25 met verwijzingen; J. De Meyer, 'Réflexions sur la monarchie parlementaire', Res Publica, I96I, p. 245; Ch. De Visscher, 'La Fonction royale', p. 684-685; W.J. Ganshof van der Meersch, 'Le commandement de l'armée et la responsabilité ministérielle en droit constitutionnel belge', p. 269; P. Wigny, Droit Constitutionnel, t. II, p. 574, nr. 426: '(...) en cas de résistance opiniâtre, il lui (le ministre) reste la liberté et le devoir de démissioner. Un nouveau gouvernement devra tenir compte, lui aussi, d'une volonté inchangée des Chambre. (...) La volonté de la majorité parlementaire doit finalement l'emporter.' 
steeds de stand van het Britse $\mathrm{e}^{232}$ en het Nederlandse $\mathrm{e}^{233}$ constitutioneel recht te zijn. De Koning zou zijn handtekening kunnen weigeren, maar steeds wordt er wel aan toegevoegd dat het ondenkbaar is dat het ooit zo ver zal komen. Misschien zou men dit standpunt kunnen duiden aan de hand van het onderscheid dat A.V. Dicey maakt tussen 'the law of the constitution', het ongeschreven en geschreven grondwettelijk recht enerzijds en de 'conventions of the constitution' anderzijds. Het gaat dan om politieke gebruiken die doorheen de jaren zijn gegroeid. Ze missen 'force of law', zijn niet afdwingbaar voor de rechtbanken. Dicey rekent ze niet tot de 'law of the constitution'. Ze behoren volgens hem tot de 'constitutional morality'. Ze betreffen o.m. de verhouding tussen Koning en ministers en de uitoefening van een aantal 'discretionaire' koninklijke prerogatieven. Ze zorgen ervoor dat de Kroon er slechts gebruik van maakt op een wijze die in overeenstemming is met de wil van de bevolking zoals die tot uiting komt in de instellingen van het parlementair systeem. ${ }^{234}$ De prerogatieven van de Koning komen zo onder controle van zijn ministers die regeren met steun van de meerderheid in het parlement. ${ }^{235}$

232 De Britse koning handelt 'on advice' van zijn ministers. In theorie kan hij dat advies naast zich neerleggen. In de praktijk zal dit betekenen dat de regering ontslag zal nemen en dat de koningin in onmin zal leven met een van de twee belangrijkste partijen van het land. Bogdanor schrijft: 'No constitutional sovereign can survive for long once he or she comes to be seen as a partisan.' V. Bogdanor, The Monarchy and the Constitution, Oxford, Clarendon Press, p. 66.

233 Minister-president Kok stelde in zijn brief over het koningschap (2000): 'In het licht van de ministeriële verantwoordelijkheid en de in 1983 vastgelegde regels en de zich sindsdien ontwikkelende praktijk is de Koning zich zeer bewust van de onmogelijkheid om van de bevoegdheid tot weigering gebruik te maken. Dat is een materieel feit.' (Handelingen II 200o200I, 580). Hierover schreven Vermeulen c.s.: 'Tegengeworpen kan worden dat de Grondwet de Koning toch nog steeds een eigen beslissingsbevoegdheid toekent, die onder omstandigheden kan leiden tot een blokkade van het kabinetsvoornemen. Gesteld kan worden dat de door Kok geschetste gang van zaken slechts staatkundige praktijk is, en geen staatsrechtelijke norm, zodat de Koning rechtens niet verplicht is zich bij het kabinetsvoornemen neer te leggen.' Zie B.P. Vermeulen, A.P. Krijnen en D.A. Roos, De Koning in het Nederlandse staatsrecht, Ars Aequi libri, Nijmegen, 2005, p. 90-9I. Zie ook J. Vis, 'De staatsrechtelijke ruimte van Koningin Beatrix,' in C.A. Tamse (red.), De stijl van Beatrix. De vrouw en het ambt, Amsterdam, Uitgeverij Balans, 2005, p. 40-43.

234 Zo is het op basis van 'conventions' dat de koning de leider van de partij die als grootste uit de verkiezingen naar voor komt tot 'prime minister' benoemt, dat His Majesty's Government collectief verantwoordelijk is voor het Lagerhuis, dat ze aanblijft zolang ze het vertrouwen behoudt van het Lagerhuis, dat de koning in beginsel handelt op advies van een minister, dat hij zich verre houdt van parlementszittingen en niet deelneemt aan kabinetszittingen, dat hij jaarlijks het parlement bijeenroept en ook dat hij een door de volksvertegenwoordiging aanvaard wetsontwerp behoort te bekrachtigen. Ook de regel dat de koning zijn vetorecht niet uitoefent ten aanzien van door het parlement goedgekeurde wetten, is een 'politieke stelregel', een 'convention of the constitution'.

235 A.V. Dicey, An introduction to the study of the law of the constitution, Londen, I959, p. 429: 'Having ascertained that the conventions of the Constitution are (in the main) rules determining the exercise of the prerogative, we may carry our analysis of their character a step further. They have all an ultimate object. Their end is to secure that parliament shall in the long run give effect to the will of that power which in modern England is the true political sovereign of the State, the majority of the electors of (to use popular though, not quite accurate language) the nation.' Wade en Bradley, Constitutional law, I965, 7e dr., p. 5; Wheare, K.C., Modern constitution, Londen, I975, 3e dr., p. I35; Mitchell, J.D.B., Constitutional law, Edinburgh, I968, p. 36; Hood Philips, Constitutional and administrative law, Londen, I973, 8I; Zie ook A.H.M. Dolle, Over ongeschreven staatsrecht, Zwolle, I988, p. 67-68. 


\section{De Koning, de ontslagnemende regering en de lopende zaken}

-7I. Wanneer een regering niet meer steunt op een meerderheid in het parlement, wijzigt echter ook de positie van het staatshoofd. Dat is met name het geval wanneer de regering ontslag heeft genomen - na verkiezingen of wegens een crisis in de schoot van de meerderheid - of wanneer de Kamers ontbonden zijn. In beide gevallen is de regering nog slechts met de lopende zaken belast. ${ }^{23^{6}}$ Het gaat om een praktijk die door ongeschreven grondwettelijk recht wordt beheerst. ${ }^{237}$ Meer bepaald gaat het om een grondwettelijke gewoonte die geënt is op twee constitutionele beginselen. Enerzijds is er het continuïteitsbeginsel dat vergt dat de overheid - en ook de regering - haar taken ononderbroken blijft vervullen en anderzijds is er het beginsel van het parlementair systeem, dat vergt dat een regering slechts op basis van het vertrouwen of het gedogen van een meerderheid in het parlement kan optreden. De combinatie van deze twee beginselen leidt ertoe dat een ontslagnemende regering dient aan te blijven totdat een nieuwe regering is gevormd, maar dat ze zich dient te beperken tot de 'lopende zaken' omdat ze niet meer ten volle onder controle van de Kamer van volksvertegenwoordigers staat. ${ }^{238}$ Die regering moet haar ambities temperen. Volgens de rechtspraak ${ }^{239}$ en de unanieme rechtsleer is dit de ultieme ratio constitutionis. Ze geldt niet alleen in geval de regering ontslag heeft genomen, doch ook in geval het parlement ontbonden is. Ook dan is er van parlementaire controle uiteraard geen sprake meer. Ook dan dienen de bevoegdheden van de regering tot de lopende zaken beperkt te blijven. ${ }^{240}$

-72. Het is in de eerste plaats de eerste minister die erover waakt dat zijn regering zich tot de lopende zaken beperkt. Na het ontslag van de regering, stuurt hij aan zijn collega's een rondschrijven om hen de beginselen ter zake in herinnering te brengen. ${ }^{24 \mathrm{I}}$ Daarenboven is het al voorgekomen dat hij een collega-minister terugfluit,

236 Zie P. Popelier, 'Lopende zaken: over een regering zonder vertrouwen en een parlement zonder motor', C.D.P.K., 2008, p. 94-III; J. Velaers en Y. Peeters, 'De lopende zaken en de ontslagnemende regering', T.B.P., 2008, p. 3-I9; J. Velaers: 'België, een land in crisis, een regering in lopende zaken', Ned. Tijdsch. Constitutioneel recht, september $201 \mathrm{I}$.

237 Op federaal niveau althans. Voor de Gemeenschappen en Gewesten zijn de 'lopende zaken' uitdrukkelijk opgenomen in artikel 73, lid 2, van de Bijzondere Wet van 8 augustus I980 tot hervorming der instellingen; artikel 36 \$I van de Bijzondere Wet van I2 januari I989 met betrekking tot de Brusselse Instellingen en artikel 5I van de Wet van 3I december 1983 tot hervorming der instellingen voor de Duitstalige Gemeenschap.

238 De ontslagnemende regering kan weliswaar nog steeds over haar beleid worden ondervraagd en geïnterpelleerd. Indien de Kamer haar beleid afkeurt, kan ze haar echter niet meer tot ontslag dwingen. Ze heeft er geen vat meer op. Ze is als een tandenloze tijger. De sanctie op de ministeriële verantwoordelijkheid ontbreekt.

239 Zie R.v.St., vzw Association du personnel wallon et francophone des services publics t. BS, nr. I7.I3I, I4 juli I975 en Cass. 4 februari I999, R.W. I999-2000, 432: Zie ook het advies van de R.v.St., afd. Wetgeving, over het koninklijk besluit van 22 november I99I tot bepaling van de algemene principes van het administratief en geldelijk statuut van de rijksambtenaren, B.S. 24 december I99I, 29.404 en 29.405 .

240 Dit wordt thans ondubbelzinnig erkend in de rechtspraak van de Raad van State. Zie R.v.St., Ory, nr. 47.69I, 3 I mei I994; R.v.St., Leclercq, nr. 47.689, 3 I mei 1994 en R.v.St., vzw Onderling Steunfonds Syndoc (OSS) t. BS, nr. 69.331, 3 november 1997.

24I OmzendbriefY. Leterme, 'Lopende zaken', 26 april 2010. 
door de Koning aan te bevelen een voorgelegd besluit niet te ondertekenen, omdat dit volgens hem niet tot de lopende zaken behoort. ${ }^{242}$ Ook de Koning zelf ziet erop toe dat een ontslagnemende regering de grenzen van haar bevoegdheid niet te buiten gaat. ${ }^{243}$ Dat een regering die 'aan het einde van haar Latijn' is gekomen, geneigd kan zijn haar macht te overschrijden, bv. door nog vlug enkele belangrijke benoemingen te doen, is niet denkbeeldig. De Koning waakt erover dat dit niet gebeurt en dat de rechten van de (toekomstige) meerderheid worden geëerbiedigd ${ }^{244} \mathrm{Hij}$ zal dan ook weigeren verdachte besluiten te ondertekenen. Hij zal zich daarbij steunen op de criteria die in de rechtspraak en de rechtsleer zijn ontwikkeld ${ }^{245}$ en die overigens ook in het rondschrijven van de eerste minister in herinnering worden gebracht. Wanneer er hierover een verschil van mening bestaat tussen de Koning en zijn regering, dan zal er overleg plaats vinden. Men zal pogen overeenstemming te berei$k n^{24^{6}}$ Doordat de regering enerzijds niet meer op een meerderheid in het parlement steunt, en anderzijds ontslagnemend is en dus niet met ontslag kan dreigen indien de Koning niet tekent, is de positie van die laatste versterkt. Het komt dus voor dat de Koning het been stijf houdt. Is hij van oordeel dat een besluit niet tot de lopende zaken behoort, zal hij het wel ondertekenen, maar niet aan de ontslagnemende minister overmaken, doch bijhouden tot er een nieuwe regering is, die dan kan beslissen wat ze ermee doet. ${ }^{247}$ Gewezen eerste ministers getuigen dat dit geenszins

242 De h. Wouter Gabriels, destijds voorzitter van het directiecomité van de FOD Kanselarij verklaarde: 'In een regering van lopende zaken zijn de premier en de Kanselarij "regisseur en bewaker"'. (...) 'Toen minister André Flahaut (PS) op 29 september topbenoemingen bij het leger wou doorvoeren, is hij tegengehouden (...)'. 'Is er een piloot aan boord', Knack, 3I oktober 2007 , p. 24. Zie de controverse tussen eerste minister Verhofstadt en minister van arbeid Vanvelthoven i.v.m. de uitvoering van een wet van 1948 door een K.B. i.v.m. de verkiezing van ondernemingsraden in ondernemingen met minstens 50 werknemers. E. Maes, 'Koning gekneld tussen twee ministers', Juristenkrant, 27 juni 2007, nr. I52, p. 5.

243 In de hiervoor vermelde omzendbrief luidt het: 'Er wordt trouwens aan herinnerd dat de traditionele controle door het Staatshoofd, dat elke ondertekening weigert van een maatregel die niet als een lopende zaak kan worden beschouwd, wordt aangevuld met een rechterlijke controle door de Raad van State.'

244 J. Stengers, De koningen der Belgen, deel I, hfdst. I, I, p. I66.

245 Traditioneel worden drie categorieën van regeringsbeslissingen als 'lopende zaken' beschouwd: (I) de zaken van dagelijks bestuur, (2) de 'reeds lopende' zaken die slechts de verdere uitvoering en implementering zijn van beslissingen die reeds voor de val van de regering waren genomen en (3) de dringende zaken, die redelijkerwijze niet kunnen worden uitgesteld zonder de essentiële belangen van het land of van bepaalde categorieën van burgers ernstig te schaden.

246 Op een vraag van de h. S. Bracke over een koninklijk besluit i.v.m. met een centrale databank voor beslagberichten, dat de Koning aanvankelijk niet had getekend, antwoordde eerste minister Leterme: 'Sinds de aanvaarding van het ontslag van de regering ligt een aantal Koninklijke besluiten die de Koning moet ondertekenen op het Paleis. Over de politieke dekking van het staatshoofd en het tekenen of niet-tekenen heeft er een colloque singulier plaatsgevonden tussen de Koning en mijzelf en tussen de diensten van de Koning en mijn diensten. Dat Koninklijk Besluit is blijven liggen omdat er moest worden gekeken of het effectief binnen de lopende zaken viel. Na verloop van tijd is gebleken dat het paste binnen het concept lopende zaken en is het ondertekend en in werking getreden.' Parl. Hand., Kamer, 20I0-20II, 2I december 20I0, CRIV 53 COM 077, p. I3.

247 In de hiervoor vermelde omzendbrief luidt het: 'Behalve in gevallen van hoogdringendheid, tekent de Koning overigens geen besluiten tot benoeming of tot bevordering of besluiten die belangrijke personeelswijzigingen voor gevolg hebben. Die besluiten worden in beraad gehouden en naar de nieuwe Regering teruggestuurd. Indien ze ondertekend terugkomen, wordt aan de nieuwe Regering gevraagd ze uit te voeren indien zij hiermede akkoord gaat.' 
theorie is, maar zich in de praktijk wel degelijk voordoet. ${ }^{248}$ Zo verklaarde gewezen eerste minister Marc Eyskens in een interview: 'Ja, het kabinet van de koning kijkt nauwgezet toe of elk Koninklijk Besluit dat moet worden ondertekend in overeenstemming is met de lopende zaken. Er wordt weleens gediscussieerd over het inperken van de bevoegdheden van de koning, maar ik ben er een groot voorstander van dat de koning tijdens de lopende zaken zijn bevoegdheden behoudt: het is een garantie tegen particratisch machtsmisbruik, een kankergezwel van de Belgische democratie.' Ook gewezen eerste minister Martens herinnert zich: 'Ik hield altijd nauw contact met het kabinet van koning Boudewijn. En heel wat beslissingen werden daadwerkelijk door de koning tegengehouden. Dan werd gewoon gewacht op de vorming van de nieuwe regering. ${ }^{249}$ Dat de praktijk onder Albert II niet gewijzigd is, moge blijken uit de volgende verklaring van de minister van ambtenarenzaken Vervotte in de Kamer: 'In principe is het de lijn van deze regering om zo weinig mogelijk benoemingen te doen, om daar het continuïteitsprincipe te hanteren. Wanneer dit een probleem is, kan het dossier naar de regering worden gebracht, maar ook dan moet worden gekeken in welke mate de Koning bereid is dat te ondertekenen. De Koning hanteert daarin een strikte houding.' ${ }^{250}$

-73. Door - weze het tijdelijk - een besluit tegen te houden, oefent de Koning politieke macht uit, zonder daarin door een minister gedekt te zijn. Gelet op het feit dat de periodes van lopende zaken vaak vele weken en maanden duren, en recent zelfs meer dan een jaar, hebben we hier te maken met een niet zo marginaal fenomeen. De historicus Stengers stelt hierover nog dat aangezien de Koning optreedt op basis van een onderzoek van de dossiers door zijn kabinet men kan stellen 'dat de werkelijke zetel van de macht op dat ogenblik het Koninklijk Paleis is. ${ }^{251}$ Deze praktijk is niet onbetwist. ${ }^{252}$ Het vrijwaren van de rechten van de nieuwe meerderheid en van de regering in spe is zeker een nobel motief. De vraag rijst echter of het niet aan rechtscolleges toekomt om ter zake rechtsbescherming te bieden. In België kan de Raad van State, afdeling Bestuursrechtspraak, een besluit van de ontslagnemende regering - een koninklijk besluit of een ministerieel besluit - dat de lopende zaken te buiten gaat, schorsen en vernietigen wegens 'machtsoverschrijding' (art. I4 geco-

248 'België land van lopende zaken. Dit kan niet lang meer duren', Knack, 3I oktober 2007.

249 'Is er een piloot aan boord?', Knack, 3I oktober 2007, p. 24.

250 Parl. Hand., Kamer, 20I0-20II, 24 november 20I0, CRIV 53 COM 047, p. 6.

$25 \mathrm{I}$ J. Stengers, De koningen der Belgen, deel I, hfdst. I, I, p. I66.

252 Zie bv. S. Bracke, 'Albert II, il règne et il gouverne', 27 december 20I0: 'Het leidt tot de conclusie dat de Koning niet alleen bij een regeringsvorming politieke macht heeft. Hij oefent kennelijk ook politieke macht uit via de regering van lopende zaken. En je hoeft geen republikein te zijn om dat laatste fout te vinden. (...) Met andere woorden: de koning beslist zelf wat er lopende zaken zijn, en wat niet. En daar waar normaliter de koning tekent onder verantwoordelijkheid van één of meer ministers, beslist de man blijkbaar zelf ... Hij discussieert blijkbaar in de beslotenheid van de Colloque Singulier met de uittredende regering of ze wel binnen haar lopende zaken blijft. Waarbij onvermijdelijk de vraag is: komt dat de koning toe? Zo ja, krachtens welke grondwettelijke regel? En wie controleert daarbij de Koning? En voorts: welke besluiten houdt de man op dit moment tegen? Welke laat hij wel gaan? Hoeveel andere KB's liggen er klaar ter ondertekening, en waarom weigert hij te tekenen? En welke heeft hij eerst geweigerd te tekenen, en welke heeft hij ... uiteindelijk - toch getekend, en waarom?' www.siegfriedbracke.be/index. php/albert-ii-il-regne-et-il-gouverne/. 
ordineerde wetten op de Raad van State). Daarenboven kunnen de hoven en rechtbanken, in een concreet geschil, weigeren een dergelijk besluit toe te passen (art. I59 GW). Kan dat niet volstaan? En is dat niet wenselijk ter wille van de onverantwoordelijkheid van de Koning?

-74. Tijdens de lange regeringscrisis in 2010 en $201 \mathrm{I}$ heeft de Koning trouwens nog een andere rol gespeeld ten aanzien van de lopende zaken. Tot tweemaal toe heeft Albert II in een communiqué de ontslagnemende regering-Leterme II ertoe aangezet om ondanks de lopende zaken, er niet voor terug te schrikken om in het belang van de bevolking de nodige maatregelen te nemen. In een communiqué van 5 oktober 2010 vroeg de Koning 'het maximum te doen om het economische en sociale welzijn van de burgers te vrijwaren', ${ }^{253}$ in een communiqué van ro januari 2010 vroeg hij de begroting $201 \mathrm{I}$ voor te bereiden teneinde 'het saldo van deze begroting beter zou zijn dan wat met de Europese overheden werd overeengekomen' en in een communiqué van 2 februari 20 II vroeg hij om de begroting ook op te stellen. ${ }^{254}$ Merkwaardige communiqués. Dat een ontslagnemende regering zich tot de lopende zaken dient te beperken, impliceert immers niet dat ze verlamd is. Ze kan alle 'dringende', koninklijke en ministeriële besluiten nemen en daarenboven verzet, vanuit constitutioneel oogpunt, niets zich ertegen dat ze ook wetsontwerpen of zelfs een ontwerp van begroting bij de Kamer indient. De 'lopende zaken' tasten immers de macht van het parlement niet aan. Dat kan perfect de ontwerpen amenderen of verwerpen. In het verleden stelden ontslagnemende regeringen zich weliswaar zeer terughoudend op. Ze regeerden met 'voorlopige twaalfden' en lieten het opstellen van de ontwerpbegroting aan de volgende regering over. Vanuit politiek oogpunt was dat ook begrijpelijk. De ontslagnemende regeringen wilden immers niet het gras voor de voeten maaien van de regering in spe en misten vaak zelf de slagkracht om een begroting op te stellen. Door het lange aanslepen van de crisis en om aan Europa en de financiële markten te tonen dat België op budgettair vlak niet stuurloos is, achtte

253 Communiqué 5 oktober 20I0: De Koning heeft deze namiddag de Heer Yves Leterme, Eerste Minister, in audiëntie ontvangen op het Paleis te Brussel. De Koning heeft aan de Eerste Minister gevraagd dat de Regering van lopende zaken in nauwe samenwerking met het Parlement, het maximum zou doen om het economische en sociale welzijn van de burgers te vrijwaren in deze zeer lange periode van lopende zaken.

254 Communiqué 2 februari 20II: 'De koning heeft op woensdag 2 februari $201 \mathrm{I}$ de Heer Yves Leterme, eerste minister, in audiëntie ontvangen op het kasteel te Laken; Gelet op de lange duur van de periode van lopende zaken, heeft de koning de eerste minister gevraagd dat de regering aan het parlement de begroting 20 I zou voorleggen en de nodige maatregelen zou nemen om in de nabije toekomst te beantwoorden aan de Europese eisen op het vlak van begrotingsbeleid en structurele hervormingen voor de eerstkomende jaren. De koning heeft de eerste minister ook gevraagd dat de regering van lopende zaken alle maatregelen zou nemen op economisch, sociaal en financieel vlak om het welzijn van de burgers te vrijwaren.', Portaal Belgische Overheid. www. belgium.be/nl/nieuws/20II/news_koning_vraagt_extra_maatregelen_regering_lopende_ zaken/Zie daarover de kritiek van kamerlid Dedecker: Parl. Hand., Kamer, 20I0-20II, Io februari 20II, CRIV 53 PLEN oI7, p. IO: 'U mijnheer de premier, bent vorige week ook naar de Koning geweest. En wat hebt u daar gedaan? U hebt daar van de grondwet een vodje papier gemaakt. Uit het colloque singulier hebt u gezegd: "De koning heeft mij gevraagd een begroting op te stellen." 
de ontslagnemende regering dat niet langer houdbaar. ${ }^{255}$ In het licht van wat in het verleden gebruikelijk was, had ze blijkbaar wel wat koudwatervrees te overwinnen. Dat blijkt uit het feit dat ze zich - met een merkwaardige omkering van het grondwettelijke principe - liet dekken door de Koning, die in een publiek communiqué vroeg om een begroting op te stellen en die in de media daarvoor ook kritiek incasseerde. ${ }^{256}$ Die instrumentalisering van de Koning is problematisch. Of de ontslagnemende regering is bevoegd om een begroting op stellen en dan is het niet nodig dat de Koning haar daartoe een opdracht geeft, óf ze is daar niet toe bevoegd en dan is het uiteraard uitgesloten. De communiqués van het Paleis wekken de indruk dat de lopende zaken door de Koning kunnen worden uitgebreid. Dat is niet zo.

\section{De koning een privépersoon}

-75. Wezenlijk voor het koningschap is dat een persoon van vlees en bloed tegelijkertijd een instelling is. De koning oefent niet alleen een publieke functie uit, hij heeft ook een eigen persoonlijk, familiaal en sociaal leven. Als privépersoon is hij een burger zoals elk ander. Hij treedt dan niet onder ministeriële verantwoordelijkheid op en hoeft geen inmenging van de Kamers in zijn privéleven te dulden.257 Hij is beschermd door de artikelen in de grondwet en de internationale verdragen over de mensenrechten en is ook onderworpen aan de bepalingen van het burgerlijk wetboek. Omdat persoon en functie sterk verweven zijn, werpt het staatsrecht zijn schaduw ook over de persoonlijke levenssfeer van de koning. Er zijn nu eenmaal heel wat daden die voor de gewone burger tot het privéleven behoren, maar die als het de Koning betreft, een weerslag kunnen hebben op het openbaar belang, met als gevolg dat zij onder ministeriële verantwoordelijkheid vallen. ${ }^{25}$ De categorie 'handelingen met politieke gevolgen' - die de commissie-Soenens hanteert - is, zoals eerder aangegeven, erg ruim en slaat op alles wat een weerslag kan hebben op het

255 Zie daarover de verklaring van de eerste minister Parl. Hand., Kamer, 20I0-20II, I8 mei 20II, CRABV 53, Plen 033, p. 40: 'Een aantal factoren verplicht ons hiertoe. Wij moeten de afspraken met de Europese Commissie nakomen en de stabiliteitstrajecten volgen. Bovendien dwingen de financiële markten ons tot actie en moet de werking van de openbare instellingen gegarandeerd blijven. Er zijn dus redenen genoeg om in deze periode van lopende zaken af te stappen van het systeem van voorlopige twaalfden en over te schakelen op een effectieve begroting. Het opstellen daarvan was een moeilijke klus voor de regering die de lopende zaken strikt zou respecteren en tegelijk een volwaardig document wou indienen. De uitgaven die in deze begroting zijn opgenomen, zijn uitgaven die zoveel mogelijk teruggaan op wat de regering in het systeem van voorlopige twaalfden zou hebben kunnen uitgeven, met uitzondering van onder andere volumeen inflatie-effecten.'

256 Zie bv. Le Vif l'Express, I8-24 februari 200 'Le Roi viole-t-il la loi ?', 'Albert II, le téméraire'.

257 Zie het advies van de Nederlandse Raad van State $N^{\circ}$ OOr.Io.o8I/I, 's-Gravenhage 23 december 2010.

258 De Visscher schreef in dit verband: 'La règle d'après laquelle le Roi ne peut agir seul ... vise les actes de la personne privée du Roi lorsque ces actes sont connus du public et que, dans les circonstances particulières du moment, ils peuvent objectivement être interprétés comme ayant une incidence politique directe ou indirecte.' P. De Visscher, 'La Fonction royale', o.c., p. 682. 
staatsbelang, waarvan ook het aanzien van de monarchie een aspect is. ${ }^{259}$ Ook daarvoor draagt de regering een verantwoordelijkheid. Het lijkt evenwel een kenmerk te zijn van het Belgische staatsrecht dat het constitutioneel keurslijf voor de Koning als privépersoon, niet al te strak wordt aangespannen en dat er binnen de instelling ruimte wordt gelaten voor de persoon van de Koning. We gaan hierna in op een aantal thema's die in een recent verleden tot een activering van de ministeriële verantwoordelijkheid hebben geleid.

\section{Het privéleven van de koning}

-76. Alleen die aspecten van het privéleven van de Koning die het openbaar belang raken en rechtstreeks of onrechtstreeks geacht kunnen worden 'politieke gevolgen' te hebben, vallen onder de ministeriële verantwoordelijkheid. Omwille van de verwevenheid van persoon en functie, is het niet altijd eenvoudig een precieze scheidslijn te trekken in de grijze zone tussen publiek en privaatleven. De concrete omstandigheden zijn bepalend. Zo zal een telefoongesprek van de Koning met een bankier niet onder de ministeriële verantwoordelijkheid vallen, als het over het private vermogen van de Koning gaat, maar wel als de overname van een Belgische bank wordt besproken. ${ }^{260}$ Twee instanties brengen hun oordeel uit over de vraag of de ministeriële verantwoordelijkheid in het geding is. In de eerste plaats de voorzitters van Kamer en Senaat die een parlementaire vraag niet-ontvankelijk verklaren wanneer die louter het privéleven van de Koning betreft. ${ }^{26 r}$ En vervolgens, wanneer de vraag

259 A. Van Welkenhuyzen, $V^{\circ}$ Chef de l'État, nr. 69: 'Le prestige dont il est souhaitable que le titulaire d'une aussi haute charge soit entouré a aussi ses exigences.'

260 Zie bv. het antwoord van eerste minister Dehaene op de mondelinge vraag van de h. Van Hauthem 'over de rol die het Hof heeft gespeeld bij de overname van de Generale Bank': 'bij mijn weten is het Hof in de kwestie van de Generale Bank niet tussenbeide gekomen.' Parl. Hand., Senaat, I juni I998, I-I96. Zie anders St. Michielsen en B. Devaux, Zes huwelijken en één begrafenis, grote en kleine geheimen van de Belgische haute finance, Lannoo, 1999. Daarover ondervraagd op 24 mei 2000 door de h. Annemans antwoordde eerste minister Verhofstadt dat 'de bedoelde handelingen onder de politieke verantwoordelijkheid van de vorige regering vallen. De verantwoordelijkheid van de huidige regering kan dus niet in het geding worden gesteld.' Parl. Hand., Kamer, I999-2000, QRVA 50, 037, 3 juli 2000, p. 4227-4228.

26I Zo stelde Vlaams Blok-senator Ceder een vraag over het boek 'Achter de Maskerade' van Manu Ruys, waarin sprake was van 'de wufte escapades van Albert en Paola' en van 'de spin in het web', zijnde het Hof. De vraag werd echter door de Senaatsvoorzitter niet-ontvankelijk verklaard. Dit was voor de senatoren Ceder en Verreycken een aanleiding om de herziening van artikel 88 van de grondwet te vragen (Parl. St., Senaat, I998-I999, I-II98/I). Even later stelde ook Vlaams Blok-kamerlid G. Van Tastenhoye op 22 oktober 1999 aan eerste minister Verhofstadt een vraag over de geruchten dat koning Albert II een buitenechtelijke dochter zou hebben. Van Tastenhoye vroeg of de eerste minister over inlichtingen beschikte dat koning Albert inderdaad een onwettige dochter had, en of, indien dit het geval was, dit geen risicofactor vormde in die zin dat de Koning daardoor chanteerbaar zou kunnen zijn. Hij vroeg ook of deze 'Delphine', indien zij bestaat, in de gaten werd gehouden door de veiligheidsdiensten, zoals dat met andere leden van de koninklijke familie het geval is. Krijgt zij politionele bescherming? Wat is de kostprijs van deze eventuele bescherming en/of de activiteiten van de Staatsveiligheid in dit verband? Kamervoorzitter Herman Decroo verklaarde deze vraag op 25 oktober 1999 echter nietontvankelijk. Dat het privéleven van de Koning hier in het geding was, is duidelijk. De vragen over de bewaking op staatskosten betroffen echter het algemeen belang, en hadden dan ook dienen te worden beantwoord. 
die eerste sluis is gepasseerd, de eerste minister die nog steeds kan aangeven dat de zaak louter het privéleven van de vorst betreft, zodat ministeriële verantwoordelijkheid niet in het geding is. Telkens dient dit in concreto te worden beoordeeld.

-77. Nemen we als een voorbeeld de vakantie van de koning. In beginsel behoort die tot zijn privéleven. In bepaalde omstandigheden kan ze echter ook het openbaar belang raken, omdat er in binnen- en/of buitenland een politieke betekenis aan wordt gehecht, zodat ook minstens de perceptie ontstaat dat het buitenlands beleid in het geding is. Dat bleek met name in I96r toen het koningspaar tijdens hun vakantie in Spanje een uitnodiging aanvaardde van generaal Franco voor een diner op diens jacht. Het zou om een privébezoek gaan, maar de koning kreeg een semiofficiële ontvangst. Hij had vooraf deze ontmoeting besproken met eerste minister Theo Lefèvre en met minister van Buitenlandse Zaken Paul-Henri Spaak, die zich niet hadden verzet. ${ }^{262}$ Er stak een korte maar hevige storm van verontwaardiging op in een aantal kranten. Het Luikse kamerlid Dejardin schreef een brief aan eerste minister Lefèvre met de vraag of de regering het optreden van de koning dekte. Die antwoordde na enige tijd dat 'l'acceptation de semblable invitation n'était pas de nature à susciter d'objection ministérielle.' Tot een interpellatie in de Kamer kwam het uiteindelijk niet meer. ${ }^{263}$ Ook de terugkeer uit vakantie kan tot een activering van de ministeriële verantwoordelijkheid leiden. Dat ondervond het huidige koningspaar in augustus 1996. Na de ontdekking van de lijkjes van de door Marc Dutroux ontvoerde meisjes, keerden de koning en de koningin niet meteen uit hun vakantieoord in Frankrijk terug om in de collectieve rouw en verontwaardiging te delen. Er verschenen speculaties in de pers dat dit aan eerste minister Dehaene te wijten was die zich in een telefonisch gesprek tegen een vervroegde terugkeer van de koning zou hebben verzet. Als reactie op deze berichtgeving ging er op 27 september 1996 een gezamenlijk communiqué uit van de kabinetten van de koning en van de premier: 'De koning en de eerste minister zijn in die periode inderdaad telefonisch met elkaar in verbinding geweest. De gesprekken tussen de vorst en de eerste minister hebben een vertrouwelijk karakter'. ${ }^{264}$ Ook hier werd de ministeriële verantwoordelijkheid geactiveerd. Het ging niet louter om een private aangelegenheid. Ook de rol van de koning als staatshoofd en ook de publieke perceptie ervan, waren in het geding. Een probleem daarbij is dat de betekenis van een privaat optreden, ook van een vakantie, snel kan veranderen en dat het voor de koning en de eerste minister niet steeds eenvoudig is om daarop in te spelen. Of zoals Van Wijnen het uitdrukt: 'De koningin kan als privépersoon van huis gaan, maar als de politieke omstandigheden onderweg veranderen, komt zij als staatshoofd op haar vakantieadres aan. ${ }^{265}$

262 In die zin A. Molitor, La fonction royale en Belgique, p. I20.

263 Zie V. Delcorps, La Couronne et la Rose. Baudouin et le monde socialiste 1950-I974, Le Cri, Histoire, 2010, p. 185-I92. J. Stengers, De Koningen der Belgen, hfst. 2, I, p. 247.

264 L. Demullier, Twee Koningen vijf jaar na Boudewijn. Bijlage bij het Volk van ro juli I998.

265 H. van Wijnen, De macht van de Kroon, Uitgeverij Balans, 2000, p. I70, i.v.m. de skivakantie van koningin Beatrix in Oostenrijk op een ogenblik dat er in Europa verontwaardiging was gerezen over de deelname van Jörg Haiders partij aan de regering. 
-78. De Koning heeft zoals elke Belg het recht op een eigen religieuze en filosofische overtuiging. In een staatsbestel zonder staatsgodsdienst, met scheiding van kerk en staat, en een op levensbeschouwelijk vlak neutrale overheid die de gelijkheid van de verschillende levensovertuigingen dient te eerbiedigen, mag de levensovertuiging van de Koning uiteraard geen weerslag hebben op de uitoefening van zijn functie. De Belgische koningen zijn zich hiervan steeds bewust geweest. ${ }^{266}$ Van in het begin van de Belgische geschiedenis heeft dit echter niet belet dat de religieuze plechtigheden die bij blijde en droeve gebeurtenissen in de koninklijke familie plaatsvinden, zoals dopen, huwelijken en begrafenissen, een ruime publieke belangstelling krijgen en dat het vorstenpaar en andere leden van de koninklijke familie in het openbaar deelnemen aan religieuze plechtigheden bijvoorbeeld in het Vaticaan. Lange tijd werd dit niet problematisch gevonden.

-79. In de recente periode is in onze levensbeschouwelijk pluralistische samenleving de gevoeligheid voor alles wat aan de neutraliteit van de staat afbreuk zou kunnen doen, toegenomen. Dat bleek bv. toen de paarse regering-Verhofstadt I besliste om het Feest van de Dynastie dat sedert I83 I slechts met een Te Deum in de katholieke kerken werd gevierd, ook op meer geseculariseerde wijze, door een viering in het Parlement, in het licht te stellen. Dit is uiteraard volstrekt vanzelfsprekend. Een stap verder ging een wetsvoorstel over de scheiding van kerk en staat dat aan overheidspersonen wilde verbieden officiële plechtigheden te organiseren of eraan deel te nemen, die naar een religieuze of niet-confessionele levensbeschouwing verwijzen. ${ }^{267}$ In zijn advies merkte de Raad van State op dat het niet duidelijk was of het verbod toepasselijk zou zijn op de religieuze plechtigheden in de Koninklijke familie. ${ }^{268}$ Wel duidelijk was dat de deelname van bv. de Koning of leden van de regering aan een religieuze plechtigheid die in een vreemde staat plaatsvindt, naar aanleiding van het overlijden van het staatshoofd - bijv. de uitvaart van een paus in het Vaticaan - voortaan verboden zou zijn. De Raad merkte op dat indien het aan overheidspersonen ook verboden zou zijn als private personen aan die plechtigheden deel te nemen, dit een beperking van hun godsdienstvrijheid zou zijn, waarvoor er een verantwoording diende te worden geboden. De Raad wees er daarenboven op dat de bepaling een negatieve weerslag zou kunnen hebben op de internationale betrekkingen met staten die geen regime van scheiding van kerk en staat hebben. Belgische overheden zouden niet kunnen aanwezig zijn op de door de ambassade

266 Met uitzondering dan van de abortuskwestie waarop we later nader ingaan. Zie infra nr. 8o en v.

267 Art. 3 'Publiekrechtelijke rechtspersonen mogen noch rechtstreeks, noch onrechtstreeks, officiële plechtigheden organiseren of eraan deelnemen, als deze naar een religieuze of niet-confessionele levensbeschouwing verwijzen, in het bijzonder wegens het tijdstip of de plaats.' Parl. St., Senaat, 2007-2008, nr. 4-35I.

268 Dat zijn weliswaar geen officiële plechtigheden, maar er is soms wel sprake van enige officiële omkadering door de aanwezigheid van gezagsdragers en zelfs magistraten in toga. 
van een islamitisch land in een moskee georganiseerde religieuze plechtigheid. ${ }^{269}$ Het wetsvoorstel werd ingetrokken. Vooralsnog is het de koning dus niet verboden aan een officiële religieuze plechtigheid deel te nemen, zij het onder ministeriële verantwoordelijkheid. Dat dit nog steeds gevoelig ligt, blijkt uit de commotie die er recent ontstond over de aanwezigheid van het koningspaar en eerste minister Leterme bij de zaligverklaring van paus Johannes Paulus II in Rome.

\section{De gewetensvrijheid van de Koning}

-8o. Dat de gewetensvrijheid van de Koning tot een kortsluiting tussen persoon en instelling kan leiden is in België duidelijk geworden naar aanleiding van de weigering in 1990 van koning Boudewijn om de abortuswet te ondertekenen. Boudewijn zelf zei hierover aan een minister: 'Mijn taak en mijn leven zijn niet te scheiden'. ${ }^{270}$ Dat niet de Koning, maar de ministers verantwoordelijk zijn, is dan wel een staatsrechtelijk antwoord 'uit het boekje', maar voor het overige weinig relevant. Ook de Nederlandse koningin Juliana zei ooit aan een van haar ministers: 'Ja natuurlijk, u is politiek verantwoordelijk, maar dat neemt niet weg dat ik voor datgene waaraan ik meewerk, waar ik mijn handtekening aan geef, toch morele verantwoordelijkheid voel. ${ }^{271}$ In zijn brief aan eerste minister Martens stelde koning Boudewijn de vraag: 'Is het normaal dat ik de enige Belgische burger ben die verplicht is tegen zijn geweten te handelen in zulke belangrijke materie? Geldt de gewetensvrijheid voor allen behalve de Koning?' Voorwaar, een interessante vraag. Het antwoord had kunnen luiden: 'Neen, Sire, er zijn nog Belgen die gedwongen worden om tegen hun geweten te handelen.' Ben Vermeulen noemt de vrijheid van geweten terecht een 'onmogelijk grondrecht'. Het geweten is immers strikt individueel, oeverloos en niet controleerbaar. Het kan voor ieder mens anders zijn. Het kan in zeer uitlopende situaties opduiken en het is niet objectiveerbaar. ${ }^{272}$ Het recht slaagt er dan ook niet in om, in het algemeen, ${ }^{273}$ toe te laten zich op grond van gewetensbezwaren te onttrekken aan rechtsplichten. Burgers die bv. na het stemmen van de abortuswet, gewetensbezwaren inriepen tegen het betalen van bijdragen in de ziekteverzekering omdat die ook voorziet in de terugbetaling van de kosten van de abortus, vonden geen gehoor. Niet alle gewetensbezwaren worden erkend. Vooral personen met een uiterst fijngevoelig geweten ervaren dat. Dat neemt uiteraard niet weg dat het legitiem is om te pogen, in de mate van het mogelijke, toch aan de gewetensnood van

269 Advies R.v.St., afd. Wetg., nr. 44.52I/AV, 20 mei 2008, over een voorstel van wet 'houdende toepassing van de scheiding van de Staat en de religieuze of niet-confessionele levensbeschouwelijke organisaties of gemeenschappen', Parl. St., Senaat, 2007-2008, nr. 4-351/2.

270 W. Claes, 'Indrukken en beschouwingen', in 'Wij, Koning der Belgen. I83I-I98I. I50 jaar Grondwettelijke monarchie', Brussel, Gemeentekrediet, I98I, 25.

27 I W. Drees sr., 'Kroon en ministers', in C.A. Tamse (red.), De monarchie in Nederland, Amsterdam/ Brussel, I980, p. I50.

272 B.P. Vermeulen, De vrijheid van geweten, een fundamenteel rechtsprobleem, Gouda Quint Arnhem, I989, p. 345 .

273 Wel kan de wetgever bepaalde gewetensbezwaren erkennen omdat hij weet dat ze bestaan en omdat hij ze binnen een wettelijk kader op een enigszins controleerbare wijze denkt te kunnen erkennen. De gewetensbezwaren tegen de militaire dienst zijn hiervan een voorbeeld. 
eenieder en dus ook van de Koning, tegemoet te komen. Dat Boudewijn geen twijfel had laten bestaan over zijn 'Bereitheit zur Konsequenz' door troonsafstand te doen, legde een hoge druk op de regering.

-8r. Op geen enkel ogenblik suggereerde koning Boudewijn zijn gewetensprobleem op te lossen door een veto te stellen en de abortuswet niet te bekrachtigen. Hij wilde niet ingaan tegen het parlement. Hij wist ook dat geen minister bereid zou zijn het veto te dekken. In een parlementair systeem is een regering niet in staat tegen de meerderheid in het parlement in te gaan. In de Belgische geschiedenis is het vetorecht dan ook slechts driemaal onder ministeriële verantwoordelijkheid uitgeoefend. Het laatst gebeurde dat in 1884 . Inmiddels is het uitgedoofd. ${ }^{274}$ Eerste minister Martens schreef in zijn brief aan de koning dat de goede werking van instellingen vergt 'dat een door beide Kamers aangenomen wetsontwerp moet worden bekrachtigd, afgekondigd, bekendgemaakt en in werking moet treden.' Ook in een opinie van de Commissie van Venetië wordt, op grond van een rechtsvergelijkend onderzoek gesteld: 'The monarch's sanction is obligatory, if the sanction is recommended by the parliamentary government. ${ }^{275}$

-82. Het conflict tussen persoon en instelling kon evenmin worden opgelost door een tijdelijk neerleggen van het koninklijk gezag. De Belgische grondwet laat dat niet toe. ${ }^{276}$ Met nogal wat constitutionele creativiteit zocht de regering een oplossing in artikel 93 van de grondwet ${ }^{277}$ over de 'onmogelijkheid om te regeren'. Het scenario voltrok zich in drie fasen: (I) de ministerraad stelde op 3 april 1990 vast dat de Koning in de onmogelijkheid was om te regeren; (2) op grond van een analoge toepassing van artikel 9I van de grondwet over het overlijden van de Koning ${ }^{278}$ ging de ministerraad ervan uit dat hij daardoor meteen de macht van de Koning overnam en tekende nog dezelfde dag de abortuswet; (3) de Verenigde Kamers werden op 4 april I990 verzocht om op grond van een wet van I9 juli $1945^{279}$ meteen het einde van de

274 Zie J. Velaers, 'Op de grens van grondwet en politiek. Enkele beschouwingen bij het uitgedoofd koninklijk vetorecht', in Publiek recht, ruim bekeken. Opstellen aangeboden aan J. Gijssels, Antwerpen, Maklu, I994, p. 484 en v.

275 Opinion $\mathrm{n}^{\circ}$ 227/2002, CDL-AD (2002) 32, I6 december 2002, on the amendments to the Constitution of Liechtenstein proposed by the princely House of Liechtenstein, nr. I 2 en v.

276 Anders dan de Nederlandse Grondwet waarvan artikel 36 bepaalt: 'De Koning kan de uitoefening van het koninklijk gezag tijdelijk neerleggen en die uitoefening hervatten krachtens een wet, waarvan het voorstel door of vanwege hem wordt ingediend. De Staten Generaal beraadslagen en besluiten ter zake in verenigde vergadering.' Artikel 37 voegt eraan toe: 'Het koninklijk gezag wordt uitgeoefend door een regent ... d) indien de Koning de uitoefening van het koninklijk gezag tijdelijk heeft neergelegd.'

277 Artikel 93: Indien de Koning in de onmogelijkheid verkeert te regeren, roepen de ministers, na deze onmogelijkheid te hebben laten vaststellen, de Kamers bijeen. Door de verenigde Kamers wordt in de voogdij en in het regentschap voorzien.'

278 Artikel 9o, tweede lid GW: 'Te rekenen van het overlijden van de Koning en tot de eedaflegging van zijn troonopvolger of van een Regent, wordt de grondwettelijke macht van de Koning in naam van het Belgische volk uitgeoefend door de in raad verenigde ministers en onder hun verantwoordelijkheid.'

279 Wet I9 juli 1945 strekkend tot het voorzien in de uitvoering van artikel 82 van de Grondwet, B.S., 2I juni ig6r. 
onmogelijkheid om te regeren vast te stellen, wat ze op 5 april I99o ook deden. Op het eerste zicht is men geneigd te denken: goed gevonden! Probleem opgelost! Zowel de monarchie als de democratie gespaard! De abortuswet was bekrachtigd en aan de gewetensvrijheid van de koning was recht gedaan. Het land werd een constitutionele crisis, een tweede koningskwestie, bespaard. Er was slechts één schaduwzijde: het was every inch ongrondwettig. Het stond op gespannen voet met elk van de onderdelen van artikel 93 van de grondwet. (I) Het begrip 'onmogelijkheid om te regeren' kan weliswaar ruim worden geïnterpreteerd ${ }^{280}$ maar het veronderstelt minstens een toestand die het regeren als zodanig onmogelijk maakt en niet slechts het stellen van bepaalde regeringsdaden. ${ }^{28 \mathrm{r}}$ (2) Het is niet door een beslissing van de ministerraad dat de 'onmogelijkheid om te regeren' ingaat, maar wel door een beslissing van de Verenigde Kamers die ook de regent aanduiden. ${ }^{282}$ Vandaar dat er - anders dan bij het overlijden van de Koning - geen bepaling is die de ministerraad aanwijst om de macht van de Koning uit te oefenen in de periode tussen de vaststelling van de onmogelijkheid om te regeren en de aanduiding van de regent. Die twee momenten vallen immers samen. (3) Ten slotte ging het er nooit om de Verenigde Kamers een regent te laten aanduiden - het doel van de procedure over de onmogelijkheid om te regeren - maar alleen om de ministerraad in de mogelijkheid te stellen de abortuswet te bekrachtigen. Een schoolvoorbeeld van wetsontduiking.

-83. De constitutionele creativiteit die in 1990 werd opgebracht, stemde iedereen wel gelukkig. Immers: 'All's well, that ends well'. Toch vond niemand dat dit voor

280 Zie reeds G. Beltjens, Encyclopédie de droit civil, 4I3, nr. 2, 'Si le Roi majeur tombe en démence ou se trouve autrement dans l'impossibilité de régner, les Chambres sont convoqués immédiatement ...' Zie ook A. Giron, Droit Public de la Belgique, Brussel, Manceaux, I884, p. II5; M. Vauthier, 'Droit constitutionnel - Régence', Rev. Adm., I946, p. 204.

28I M. Leroy, 'Sanction royale, Constitution et droits de l'homme', in Le Soir, ig april I99o.

282 Uit de parlementaire voorbereiding van de wet van I9 juli I945 blijkt dat de procedure die in 1940 werd gevolgd, toen de onmogelijkheid om te regeren meteen inging, zonder dat de Verenigde Kamers samenkwamen, alleen door overmacht is te verklaren en niet als precedent voor normale tijden kan worden beschouwd. Het verslag van de senaatscommissie is ter zake duidelijk. Verslaggever Rolin stelde: 'In strijd met de mening uitgedrukt in de loop van de besprekingen in de Kamer, behoudt deze bepaling (art. $82 \mathrm{GW}$ ) aan de regering niet de vaststelling voor van de onmogelijkheid te regeren; de Verenigde Kamers belast met de verkiezing van de Regent, hebben noodzakelijk het recht en de plicht vooraf de gegevens ter beoordeling te onderzoeken welke de regering hun overmaakt in verband met de onmogelijkheid te regeren welke zij heeft doen vaststellen.' (Parl. Hand., Senaat, I8 juli I945, 458) Ook minister van Buitenlandse Zaken Spaak bevestigde deze zienswijze: '(...) on lit toujours d'une manière un peu hâtive l'article 82 de la Constitution et l'on semble croire que c'est le gouvernement qui doit constater l'impossibilité de régner. Le gouvernement a une obligation pour ainsi dire matérielle. Il doit faire constater l'impossibilité de régner et puis il doit convoquer le parlement' (Parl. Hand. Senaat, I8 juli i945, 466). Senator Coulonvaux bevestigde eveneens: '(...) les Chambres saisies, elles ont qualité pour vérifier si le fait de l'impossibilité existe ou n'existe pas. (...) le véritable pouvoir d'admettre, d'enregistrer, d'accueullir comme vraie l'impossibilité de régner appartient au parlement tout seul. (...) En vertu du texte formel de la Constitution seul, le parlement est investi de ce droit.' (Parl. Hand. Senaat, I8 juli I945, 467). De wetgevende Kamers moeten het einde van de onmogelijkheid om te regeren vaststellen, omdat ze ook het begin moeten vaststellen. Zie J. Velaers en H. Van Goethem, Leopold III; De Koning, het land, de oorlog, Lannoo, I994, p. 979982 . 
herhaling vatbaar was. ${ }^{283}$ In zijn brief aan de koning van 3 april 1990 schreef eerste minister Martens: 'Om te vermijden dat in de toekomst gelijkaardige problemen zouden rijzen, heeft de regering de bedoeling een structurele wijziging voor te stellen. ${ }^{284}$ Van dat voornemen werd niet meteen werk gemaakt. Na de troonsopvolging in 1993 deed eerste minister Dehaene, op verzoek van koning Albert II, wel een poging om een oplossing te vinden. De Koning zou de mogelijkheid krijgen om bij de ondertekening van een wet, aan de bekrachtigingsformule, overwegingen toe voegen, waaruit kon blijken dat hij alleen als instelling en niet als persoon instemde met de wet. ${ }^{285}$ De politieke partijen zouden er zich in een zogenoemde 'gentlemen's agreement' toe verbinden hierover geen debat uit te lokken. In 1995 lekte deze ingewikkelde constructie uit ${ }^{286}$ en werd meteen door iedereen verworpen. Ze impliceerde immers dat er twee soorten wetten zouden zijn, die waartegen de Koning wel en die waartegen hij geen bezwaren had. Het 'gentlemen's agreement' zou nauwelijks afdwingbaar zijn en stond op gespannen voet met de vrijheid van meningsuiting. De 'oplossing' werd dus afgevoerd. Het probleem bleef bestaan. Volgens een recent boek zou Koning Albert hebben overwogen de euthanasiewet niet te tekenen. Zijn toenmalige eerste minister Verhofstadt zou hem echter met forse taal overtuigd hebben: 'Sire, het is nee. Dit is onbespreekbaar. Men heeft uw broer zijn demarche vergeven omdat hij een heilige was, maar men zal u een gelijkaardige houding nooit vergeven.' ${ }^{287}$

283 Zie bv. het debat later in de Senaat, Parl. Hand., Senaat, I989-I990, I9 april I990, I900-I935. F. Delpérée, 'Faut-il reviser l'article 69 de la Constitution ?' Journ. Procès, 20 april r990, Io; R. Lallemand, 'La conscience royale et la représentation de la Nation. Réflexions à propos d'une crise', J.T. ? I990, 465-469; M. Leroy, 'Sanction royale, Constitution et droits de l'homme', Le Soir, I9 april I990. R. Ergec, en M. Uyttendaele, 'La monarchie en Belgique - Reflet du passé ou nécessité nationale?' in Présence de droit public et des droits de l'homme. Mélanges offerts à Jacques Velu, Brussel, Bruylant, I992, p. 597-6I4; R, Visker, 'Ontregeling van de democratie? Over de plaats van de koning en de zorg voor het politieke', in Onze Alma Mater, Leuvense perspectieven, I990/3, p. 212-227; de Raad van State achtte zich niet bevoegd te oordelen over de toepassing van artikel 93 van de Grondwet. Zie R.v.St., nr. 48.008, I5 juni I994, J.T., I996, 7 noot M. Rigaux.

284 Zie ook de verklaring van de eerste minister in de Kamer. Parl. St., Kamer, I99o-9I, nr. Io/6oI53I/2, p. 2.

285 Volgens art. 3 bis van het voorontwerp zou het kunnen gaan om een overweging die 'het belang van de te bekrachtigen wet in de Belgische rechtsorde benadrukt, die de te bekrachtigen wet plaatst in het raam van de rechten van de mens en de fundamentele vrijheden, die de te bekrachtigen wet plaatst in het raam van de verhouding tussen de takken van de wetgevende macht, of die de te bekrachtigen wet situeert in het raam van de verhouding tussen de federale overheid en de gemeenschappen en de gewesten'.

286 L. Neuckermans en P. Van den Driessche, Albert Koning na Boudewijn, Leuven, Van Halewijck, I995, p. II9.

287 S. Samyn en M. Buxant, Koning zonder land, p. Io8. 
-84. Ook in de recente periode is opnieuw nagedacht over structurele oplossingen. ${ }^{288}$ Een wijziging van artikel oog van de grondwet wordt overwogen. ${ }^{289}$ Dat artikel bepaalt dat de Koning de wetten bekrachtigt en afkondigt. Traditioneel wordt de bekrachtiging gedefinieerd als de 'handeling waarbij de Koning, als tak van de wetgevende macht, zich akkoord verklaart met het door de Kamers aangenomen wetsontwerp of wetsvoorstel', terwijl de afkondiging de 'handeling is waarbij de Koning, als hoofd van de uitvoerende macht, het bestaan van de wet bevestigt en beveelt dat ze met 's lands zegel bekleed en in het Belgische staatsblad bekendgemaakt wordt'. ${ }^{29}$ Aangezien het wellicht vooral de bekrachtiging is die tot gewetensbezwaren leidt, omdat die een 'akkoordverklaring' impliceert, zou men alleen de afkondiging van de wetten aan de Koning kunnen laten. Dat is de oplossing waarvoor de Luxemburgse grondwetgever op I2 maart 2009 opteerde, nadat groothertog Henri had geweigerd de euthanasiewet te bekrachtigen. ${ }^{291}$ Ook al volstaat dit wellicht om een herhaling van de gebeurtenissen van 1990 te voorkomen, een echt structurele oplossing is het niet. Het biedt immers alleen een oplossing voor een gewetensbezwaar dat rijst ten aanzien van een door de Kamers aangenomen wet. Gewetensbezwaren kunnen echter ook rijzen ten aanzien van de wetsontwerpen die de regering wil indienen of de ontwerpen van koninklijk besluit die ze ter ondertekening voorlegt. ${ }^{292}$ Ook dan zou de Koning kunnen weigeren zijn medewerking te verlenen. Wil men een echt structurele oplossing, voor elk mogelijk gewetensprobleem, dan komt men onvermijdelijk uit bij een ceremoniële of protocollaire monarchie.

\section{$4 \quad$ De Koninklijke familie}

-85. De grondwet stelt niet alleen een monarchie in, maar ook een dynastie: een familie waarbinnen de kroon volgens de regels van erfopvolging, van generatie op generatie, wordt overgedragen. De familie van de Koning is een essentieel aspect van de monarchie, omdat zij de toekomst ervan waarborgt en ook mee de stabiliteit

288 In de verklaring tot herziening van de Grondwet die 'koninklijk onderhandelaar en bemiddelaar' Dehaene in april 20 Io voorbereidde kwamen ook de artikelen Io8, Io9 en IIo voor over respectievelijk de uitvoering van de wetten, de bekrachtiging en de afkondiging van de wetten en het genaderecht. In de verklaring tot herziening van de Grondwet van 7 mei 2010 (B.S. 7 mei 20I0) werden deze artikelen uiteindelijk niet opgenomen. Zie B. Dalle, 'Overzicht van de communautaire onderhandelingen sinds 2007. Een straatje zonder eind of de weg naar verandering', TBP, oktober $201 \mathrm{I}$, nr. 54 en 63.

289 'De Koning bekrachtigt de wetten en kondigt ze af.' Zie over de verschillende pistes: F. Delpérée, 'Le Roi sanctionne les lois', J.T. , I99I, p. 593.

290 A. Mast en J. Dujardin, Overzicht van het Belgisch Grondwettelijk recht, gde druk, Brussel, I987, nr. I80-I8I.

29I Zie artikel 34: 'Le Grand-Duc promulgue les lois dans les trois mois du vote de la Chambre.' Zie ook het advies over het projet de révision de l'article 34 de la Constitution van de Luxemburgse Raad van State, 9 december 2008, Chambre des Députés, Session ordinaire 2008-2009. N5967. Zie ook het advies van de Commissie van Venetië 'sur le projet de révision constitutionnelle du Luxembourg', I4 december 2009, Avis n 544/2099.

292 Wanneer de regering, bijvoorbeeld, als een loutere hypothese, een ontwerp van Koninklijk besluit voorlegt, dat voorziet in een regeling voor de terugbetaling, in het kader van de ziekteverzekering, van de medische kosten van een abortus, kan dit uiteraard even goed op een gewetensbezwaar stuiten. 
en de continuïteit van de staat zichtbaar maakt. En ten slotte ... 'een familie op de troon is leuk om naar te kijken'. Bagehot schreef dat reeds en vele burgers vinden dat nog steeds, tot groot jolijt van de royaltypress. ${ }^{293}$

-86. In België is er geen globale regeling van het statuut van de leden van de koninklijke familie. Anders dan in Nederland hebben wij geen wet die precies bepaalt welke de leden van het Koninklijk Huis zijn. Ook hun statuut, hun rechten en plichten, zijn niet duidelijk geregeld. Slechts enkele aspecten ervan worden in de grondwet vermeld. Zo kan geen lid van de Koninklijke familie minister zijn (art. $98 \mathrm{GW}$ ). De kinderen van de Koning kunnen wel vanaf achttien jaar senator van rechtswege worden (art. $72 \mathrm{GW}$ ). De bedoeling van de grondwetgever in I83I was dat zij zo vertrouwd zouden raken met de werking van de instellingen. In onze tijd beperkt het lidmaatschap van de senaat zich tot het houden van een toespraak bij de eedaflegging over een thema dat tot weinig politieke controverse aanleiding geeft en tot het bijwonen van enkele vergaderingen. Ook de senatoren van rechtswege genieten de parlementaire immuniteit (art. $58 \mathrm{GW}$ ) en onschendbaarheid (art. $59 \mathrm{GW}$ ) en zijn tevens onderworpen aan de verplichting om een aangifte van mandaten, ambten en beroepen en een vermogensaangifte te doen. ${ }^{294}$ In de eenentwintigste eeuw heeft het senatorschap van rechtswege vooral een symbolische betekenis. De vraag kan echter gesteld worden of het niet om een inhoudsloos en zelfs om een verkeerd symbool gaat. Er werden reeds vaak voorstellen ingediend om artikel 72 van de grondwet te herzien. Tot nu toe zonder gevolg. Bij de herziening van het tweekamerstelsel in 1993 werd in een verklaring tot herziening van de grondwet nog overwogen om 'kamerleden van rechtswege' in te stellen. ${ }^{295}$ Vanaf 1996 werd zelfs gebroken met de gedurende ${ }^{6} 65$ jaar bestaande traditie ${ }^{296}$ dat er slechts één senator van rechtswege zetelt, nl. de vermoedelijke troonopvolger. Thans zetelen niet alleen prins Filip, maar ook prinses Astrid, thans zesde in de lijn van de troonopvolging en prins Laurent, twaalfde in de lijn van de troonopvolging, in de Senaat.

-87. Alleen de Koning zelf is volgens de grondwet onschendbaar. De leden van de koninklijke familie zijn dat niet, noch strafrechtelijk, ${ }^{297}$ noch burgerrechtelijk, noch

293 Bagehot schreef : 'A family on the throne is an interesting idea also. It brings down the pride of sovereignty to the level of pretty life.' W. Bagehot, The English Constitution, p. 23.

294 Wet 2 mei 1995 betreffende de verplichting om een lijst van mandaten, ambten en beroepen, alsmede een vermogenaangifte, in te dienen, B.S., 26 juli 1995.

295 Zie Verklaring tot herziening van de Grondwet, B.S., I8 oktober I99I; Zie Parl. St., Kamer, I99II992, I79I/I, p. 4.

296 Leopold II, Albert I, Leopold III en Albert II waren senator van rechtswege voor hun troonsbestijging.

297 Behoudens de immuniteit (art. $58 \mathrm{GW}$ ) en de onschendbaarheid (art. 59 GW) die ze desgevallend als senator van rechtswege genieten. De artikelen 5 Io tot 513 van het Wetboek van Strafvordering houden wel een bijzondere regeling in over de wijze waarop getuigenissen van 
politiek. Ook de ministeriële verantwoordelijkheid geldt in beginsel slechts voor de koning en niet voor de leden van de koninklijke familie. Uit de staatsrechtelijke praktijk blijkt echter dat er weliswaar wel geen rechtstreekse maar wel een onrechtstreekse ministeriële verantwoordelijkheid bestaat. ${ }^{298}$ We dienen verschillende situaties te onderscheiden.

a De politieke verantwoordelijkheid voor de officiële opdrachten die de leden van de koninklijke familie vervullen.

-88. Aan leden van de koninklijke familie worden soms bijzondere opdrachten toegekend. Zo werd prins Filip bij besluit van de in Raad Verenigde Ministers van 6 augustus 1993 benoemd tot ere-voorzitter van de Belgische Dienst van Buitenlandse Handel, ${ }^{299}$ een functie die, na de regionalisering van de buitenlandse handel in 200I, op grond van een samenwerkingsakkoord van 24 mei 2002, ${ }^{300}$ werd omgedoopt tot erevoorzitter van het Agentschap voor Buitenlandse Handel. $3^{\text {or }}$ De regering is uiteraard rechtstreeks verantwoordelijk voor het verlenen van deze opdracht en voor de wijze waarop ze de handelsmissies begeleidt. Naar aanleiding van het zogenoemde Eurosystem-schandaal in de jaren zeventig ${ }^{302}$ werden ter zake afspraken gemaakt. Prins Albert leidde toen een handelsmissie in Saoedie-Arabië, waar hij zich inzette voor een consortium 'Eurosystem Hospitalier' van Belgische ondernemingen die een project ter waarde van 740 miljoen euro voor de bouw van ziekenhuizen in Djeddah en Ryad wilden binnenhalen. De prins bracht twee bezoeken aan de Saoedi's en ook koning Boudewijn ging op staatsbezoek. Uiteindelijk werd het project toegewezen aan het consortium. Dat ging echter in een schandaalsfeer ten onder en werd failliet verklaard. De zaak liep uit op een fiasco waarvoor de Belgische Staat opdraaide. Er rezen vragen over de rol die het Hof en meer bepaald de prins hadden gespeeld. De regering bevestigde dat de leden van de koninklijke familie alleen stappen hadden gezet op verzoek van de regering of onder haar verantwoordelijkheid. Op geen enkel ogenblik hadden zij zich gemengd in de onderhandelingen over het contract. Om de taak van de prins bij dergelijke handelsmissies duidelijker af te lijnen en ook de ministeriële verantwoordelijkheid beter te omschrijven, werd, naar verluidt op verzoek van het Hof zelf, een interministeriële werkgroep opgericht. Deze onderstreepte het belang van de aanwezigheid van de prins bij economische zendingen en pleitte ervoor dat zijn rol niet louter protocollair zou zijn doch

prinsen en prinsessen van koninklijke bloede worden afgenomen in criminele, correctionele en politiezaken. Zie daarover EHRM, 20 juni ig89, Bricmont t. België.

298 Zie hierover ook M. Kooij, 'Van de prinsenkinderen geen kwaad? Ministeriële verantwoordelijkheid voor 's Konings naasten', T.B.P., 2003, 599-6Io; A. Verlinden, 'Moet het 'Koninklijk Huis' een constitutionele positie krijgen?' T.B.P., 2003, p. 98-I07.

299 Besluit 6 augustus 1993 van de in Raad Verenigde Ministers, B.S., I2 augustus 1993.

300 Zie art. 9 Samenwerkingsakkoord van 24 mei 2002 tussen de federale overheid en de gewesten tot oprichting van een Agentschap voor Buitenlandse Handel, goedgekeurd bij wet van I8 december 2002, B.S., 20 december 2002.

$30 \mathrm{~K}$ K.B. 3 mei 2003 tot benoeming van Z.K.H. Prins Filip, Prins van België, tot erevoorzitter van de raad van bestuur van het Agentschap voor Buitenlandse Handel, B.S., I6 mei 2003.

302 Zie C. Laporte, Albert II. De biografie, Tielt, Lannoo, 2003, p. 84-88; L. Neuckermans en P. Van den Driessche, Albert Koning na Boudewijn, Leuven, Van Halewijck, I995, p. 46-47. 
uitgesproken 'operationeel' zou blijven. Tegelijkertijd werd ook de ministeriële verantwoordelijkheid voor het optreden van de prins in het kader van de handelsmissie erkend. De aanwezigheid van een minister bij de buitenlandse zendingen van de prins is sindsdien een verworvenheid. In het verleden is het dan ook vaak voorgekomen dat er mondelinge of schriftelijke vragen werden gesteld over de wijze waarop de handelsmissies onder leiding van prins Albert destijds en thans prins Filip waren georganiseerd. Het verklaart ook waarom de regering zich zeer uitdrukkelijk inliet met een interview dat de prins over de handelsmissies gaf. ${ }^{303}$

-89. Ook voor de vertegenwoordigende taken die aan de koninklijke prinsen of prinsessen door de regering worden toevertrouwd is de ministeriële verantwoordelijkheid o.i. in het geding. Wanneer zij een protocollaire rol vervullen, het staatshoofd vertegenwoordigen in binnen- en buitenland, allerlei vieringen luister bijzetten, kortom, wanneer, zij met instemming van de regering, taken uitvoeren, is de regering verantwoordelijk. Dat geldt ook voor de toespraken die het lid van de Koninklijke familie bij zo'n gelegenheid houdt. ${ }^{304}$ Niet dat de regering het prinselijk optreden strak moet regisseren, dat ze telkens moet aangeven welke de politieke 'voetangels en schietgeweren' zijn die een behoedzaam optreden vergen. De regering kan best van oordeel zijn dat ze kan vertrouwen op de feeling van de leden van de koninklijke familie of dat zij zich tot enkele afspraken kan beperken. Wanneer echter over het optreden van een lid van de Koninklijke familie in een officiële hoedanigheid vragen rijzen, is de regering aanspreekbaar.

b De politieke verantwoordelijkheid voor de reactie van de Koning en/of van de regering op het private optreden van de leden van de koninklijke familie.

-90. Voor het private optreden van de leden van de koninklijke familie draagt de regering geen rechtstreekse verantwoordelijkheid. Dat is het officiële standpunt dat opeenvolgende eerste ministers de afgelopen jaren telkens opnieuw hebben ingenomen wanneer ze in de Kamer werden aangesproken over incidenten waarin prins Filip of prins Laurent betrokken waren. De regering is niet de hoeder van de koninklijke prinsen. Ze draagt geen verantwoordelijkheid voor hun doen en laten, voor hun uitspraken en gedragingen. Ze acht zich niet verplicht de prinsen en prinsessen te begeleiden in hun sociaal of professioneel leven. Ze weigerde dan ook te antwoorden op vragen met betrekking tot de privaatrechtelijke stichting K.I.N.T., waarvan prins Laurent voorzitter was. ${ }^{305}$ Ook voor de toespraken die de kinderen van de koning als senator van rechtswege houden in de Senaat, geldt de ministeriële verantwoordelijkheid niet. ${ }^{306}$ Daarover ondervraagd in de Senaat, stelde eerste minister Verhofstadt dat de regering niet verantwoordelijk is voor de prinselijke uitspraken

303 Zie Parl. Hand., Kamer, 2005-2006, CRIV 5I PLEN 20I, 30 maart 2006, p. 23.

304 Zie bv. het antwoord van staatssecretaris Simonet op de vraag van de h. G. Tastenhoye aan de eerste minister over 'de uitspraak van Prins Filip aangaande de verantwoordelijkheid van België als Navo-gastland', Parl. Hand., Kamer, 2003-2004, CRIV 5I Com 037, 3 november 2003, p. I6.

305 Zie Vragen en Antwoorden, Kamer, I998-99, 21709 en 22.389, vragen nr. I8 en 974 van mevr. A. Van de Casteele.

306 A. Mast, o.c., p. I92-I93; J. Velu, Droit public, I, Brussel, I986, p. 403. 
en dat hijzelf van mening is 'dat leden van de koninklijke familie in deze moderne tijd perfect het recht hebben om aan het maatschappelijk debat deel te nemen en opinies te hebben over maatschappelijke ontwikkelingen.' Hij voegde eraan toe 'dat ze er echter ook moeten voor zorgen dat zij door het verwoorden van die opinies niet in polemieken terechtkomen of dat ze geen personen aanvallen.'307 Daarmee is echter niet alles gezegd. De regering mag dan al niet rechtstreeks verantwoordelijk zijn voor het private optreden van de leden van de koninklijke familie, ze is wel verantwoordelijk voor de wijze waarop de Koning en de wijze waarop zijzelf op dat optreden reageert.

-9I. Een aantal malen reeds heeft koning Albert in het publiek - via een communiqué van het Paleis - zijn ongenoegen uitgesproken over het optreden van met name prins Laurent. Toen deze bv. de zogenoemde 'hypocrisie' aanklaagde bij de herziening van de regels over de erfopvolging of toen hij recent naar Kongo reisde en daarbij het negatief advies van de regering naast zich neerlegde, reageerde het Paleis met een scherp communiqué. Uiteraard was de regering hiervoor verantwoordelijk..$^{308}$ Ook voor het uitblijven van enige reactie, zou de regering trouwens verantwoordelijk zijn geweest. De Nederlandse rechtsgeleerde Toxopeus drukte het als volgt uit: 'De grondwet kent maar één onschendbare persoon en dat is het staatshoofd. De andere leden van het Koninklijk Huis zijn helemaal niet onschendbaar. (...) De ministeriële verantwoordelijkheid wordt pas dan geactiveerd als het staatshoofd nalaat maatregelen te nemen tegen een lid dat zich niet wenst te gedragen zoals het kabinet verlangt.' ${ }^{309}$ Of met andere woorden niet het gedrag en de uitspraken van de prinsen of prinsessen zelf, doch de wijze waarop de Koning daarop al dan niet reageert, valt onder de ministeriële verantwoordelijkheid.

-92. Ook voor de eigen reacties op het private optreden van de prinsen zijn de ministers uiteraard verantwoordelijk. Wanneer een lid van de koninklijke familie bv. een strafbaar feit pleegt en het openbaar minister oordeelt om opportuniteitsredenen niet te moeten vervolgen, dan is de minister van Justitie aanspreekbaar over het al dan niet uitoefenen van het positief injunctierecht waarmee hij het parket kan dwingen de strafvervolging in te stellen. Wanneer door toedoen van een lid van de koninklijke familie het aanzien van de monarchie wordt geschaad, dan staat het aan de regering af te wegen of het nodig is hierop te reageren. Zij kan oordelen dat een reactie niet nodig is, dat de monarchie tegen een stootje kan en dat angsthazerij niet van deze tijd is. Zij kan ook door discrete contacten pogen het kwaad te voorkomen.

307 Parl. Hand., Senaat, I999-2000, 8 juni 2000, 2-54. Antwoord op mondelinge vraag van de heer Wim Verreycken aan de eerste minister over de 'verantwoordelijkheid voor prinselijke toespraken in de Senaat'

308 Eerste minister Dehaene bevestigde in de Kamer dat het communiqué van het paleis 'politiek is gedekt'. Parl. Hand., Kamer, I996-97, 30 april I997, p. I59.

309 H. Hansen, 'De Koning komt. De toekomst der oranjes en de ministeriële verantwoordelijkheid, Van Gennep Amsterdam, I993, 94-95. 
Zij kan, als het kwaad is geschied, haar afkeuring uiten over het prinselijk gedrag. ${ }^{\text {10 }}$ Die piste is de laatste jaren steeds vaker bewandeld. Alhoewel zij steeds opnieuw benadrukten niet verantwoordelijk te zijn, leverden de eerste ministers de afgelopen jaren herhaaldelijk commentaar op het optreden van de zonen van de koning dat zij niet in overeenstemming vonden met de terughoudendheid die men van koninklijke prinsen mag verwachten. De reacties gingen in crescendo. Aanvankelijk waren ze nog welwillend en omzwachteld. De eerste minister beperkte zich tot enkele wijze raadgevingen. ${ }^{31}$ Naar mate de prinsen echter recidiveerden werden ze tot de orde geroepen en klonken er hardere woorden..$^{312}$

-93. Naar aanleiding van het recentste incident rond het bezoek van prins Laurent aan Kongo tegen het advies van de regering in, stelde de eerste minister in de Kamer: 'Er is geen grondwettelijke of wettelijke bepaling met betrekking tot de zogenaamde dekking van de handelingen van de prins. Het statuut van Koninklijke prins legt prins Laurent uiteraard wel bepaalde verplichtingen op, net zoals het hem bepaalde rechten toekent, uit hoofde van de wet tot vaststelling van een dotatie, die eind $200 \mathrm{I}$ in dit Parlement is goedgekeurd. Zo is de prins verplicht tot terughoudendheid, voorzichtigheid en overleg wanneer hij daden stelt of verplaatsingen onderneemt met een mogelijke politieke dimensie.. ${ }^{313}$ De regering overweegt thans, in samenspraak met het parlement, over te schakelen naar een hogere versnelling. De prins verbond er zich in een brief aan de premier o.m. toe om voor elke buitenlandse reis die contacten inhoudt met politieke persoonlijkheden of een perspectief inhoudt op een ontwikkelingproject, voorafgaand de minister van Buitenlandse Zaken te consulteren en het advies scrupuleus op te volgen. Laurent gaf in de brief aan zich terdege ervan bewust te zijn en te aanvaarden dat het niet naleven van deze regel er automatisch toe zal leiden dat de regering de intrekking van zijn dotatie aan het parlement voorstelt. ${ }^{34}$ We komen er later op terug. ${ }^{315}$

-94. Er is dus een tendens om de ministeriële verantwoordelijkheid te doen toenemen. Terwijl de regering voorheen alleen verantwoordelijk was voor de wijze waarop ze ex post reageerde, zou ze in de toekomst verantwoordelijk worden voor de wijze

3I0 Molitor schreef hierover reeds: ‘(...) si un membre de la famille royale a un comportement critiquable ou répréhensible, le gouvernement pourrait être amené à lui adresser des reproches. Il pourrait en l'occurrence se fonder sur le tort que son attitude cause à l'institution.' A. Molitor, La fonction royale en Belgique, o.c., p I20.

3II Zie bv. het antwoord van eerste minister Verhofstadt op vragen over de kritische uitlatingen van prins Laurent over de vorige eerste minister en over de oproep van de stichting KINT, waarvan de prins voorzitter was, om te betogen tegen een gerechtelijke uitspraak in een proces ingesteld door GAIA. Parl. Hand, Senaat, 200I-2002, 28 februari 2002.

3I2 Zie het antwoord van eerste minister Verhofstadt op de samengevoegde vragen van de hh. Annemans en Cocriamont over 'de uitspraken van kroonprins Filip.' (Parl. Hand. Kamer, 20042005, CRIV 5I PLEN 096, 2 december 2004, p. 4); over de samengevoegde vragen van de hh. Laeremans en Deseyn over 'het VBO-incident rond Prins Filip.' (Parl. Hand.; Kamer, 2004-2005, CRIV 5I PLEN II6, 3 februari 2005, p. 4). Zie het antwoord van de vice-premier Onkelinx over vragen over 'het persbeleid en de zogenaamde 'missie' van prins Filip.

3I3 Zie Parl. Hand., Kamer, 20I0-20II, 3I maart 20II, p. I0-22.

3I4 'Prins Laurent moet regels volgen of verliest dotatie', De Morgen, I4 april 20 Ir.

315 Zie infra nr. IIo. 
waarop ze ex ante de regie heeft gevoerd. België lijkt dus dezelfde weg als Nederland op te gaan. In Nederland is het leerstuk over de onrechtstreekse of 'afgeleide' ministeriële verantwoordelijkheid voor de leden van het Koninklijk Huis sterker ontwikkeld dan in ons land..$^{36}$ De behartiging van het algemeen belang en de bescherming van het aanzien van de dynastie wordt als grondslag van de verantwoordelijkheid van de regering beschouwd. Men leidt eruit af dat de ministers verantwoordelijk zijn wanneer zij 'in gebreke zijn gebleven hun invloed aan te wenden tot het voorkomen van een bepaalde gedraging of als zij verzuimd zouden hebben passende maatregelen te bevorderen nadat een gedraging heeft plaatsgehad. ${ }^{317}$ Ook het Belgische staatsrecht evolueert in die richting.

\section{$5 \quad$ De medewerkers van de Koning}

-95. De Koning wordt in zijn constitutionele taken bijgestaan door een aantal persoonlijke medewerkers, die samen het 'Huis van de Koning' vormen. In het Ancien Régime, toen de monarch een autocraat was die zelf de macht uitoefende, waren de ministers de persoonlijke raadslieden van de Koning. Ze werden door hem naar goeddunken benoemd en ook weer ontslagen. Er bestond geen reden om een eigen Huis in te richten. Pas toen de ministers ook en vooral het vertrouwen van het Parlement nodig hadden om te regeren, begon de Koning beroep te doen op persoonlijke medewerkers die zijn vertrouwen genoten. Het was geen toeval dat koning George III, precies bij de invoering van het parlementaire systeem, de functie van private secretary creëerde. Aanvankelijk was die bedoeld om de strijd met de ministers aan te binden..$^{38}$ Geleidelijk groeide de private secretary echter uit tot het instrument bij uitstek waarmee de Koning de samenwerking met zijn ministers organiseert. ${ }^{\text {I9 }}$ In ons land zijn de regels over het Huis van de Koning van gewoonterechtelijke aard. Ze werden gevestigd in het prille begin van de Belgische staat. De grondwet noemt het 'Huis van de Koning' niet uitdrukkelijk. Ze houdt geen analoge bepaling in als artikel 4I van de huidige Nederlandse Grondwet dat stelt dat de Koning 'met inachtneming van het openbaar belang' zijn Huis inricht. Noch de Grondwet, noch een wet, noch een K.B. regelt het 'Huis van de Koning'. Er zijn alleen tradities en ongeschreven gewoonterecht. ${ }^{320}$

3I6 Zie E. Van Raalte, Het Koninklijk Huis en zijn leden en de ministeriële verantwoordelijkheid', Zwolle, Tjeenk Willink, I966, p. 56 e.v.; P. Rehwinkel, De minister-president: Eerste onder gelijken of gelijke onder eersten?, Zwolle, Tjeenk Willink, I99I, p. 83-85; H. Hansen, De Koning komt. De toekomst der oranjes en de ministeriële verantwoordelijkheid, Amsterdam, Van Gennep, I99I, p. I5I p.; A. Verlinden, 'Met het 'Koninklijk Huis' een constitutionele positie krijgen?', T.B.P., 2003/2, p. 99-IoI.

317 Advies W. Drees en P. Oud, Kamerstukken, II, I964-I965, 7800, nr. 8.

II8 Taswell-Langmead, English constitutional history, London, I929, p. 66r.

3 I9 A.B. Keith, Constitutional law, 7the ed., London, I939, p. I37-I38. The British Cabinet System. I830-1938, London, I939, p. 44I en v.

320 A. Molitor, La fonction royale, p. I37, A. Vanwelkenhuyzen, RPDB, nr. 58; Advies Scholsem, p. 292 . 
-96. De Koning bepaalt autonoom de organisatie en inrichting van zijn Huis en hofhouding. ${ }^{321} \mathrm{Hij}$ is vrij in het benoemen en ontslaan van zijn medewerkers. Het behoort tot het constitutioneel gewoonterecht dat de ministeriële verantwoordelijkheid hier niet geldt. ${ }^{22}$ De regering wordt wel geraadpleegd, doch uiteindelijk kiest de koning zelf zijn medewerkers. ${ }^{323}$ Ze worden benoemd in een Huisbesluit dat niet door een minister wordt mede ondertekend. De leden van het Koninklijk Huis zijn immers de persoonlijke medewerkers van de Koning. Dat wordt om twee redenen belangrijk geacht. In de eerste plaats heeft ieder die een belangrijke functie uitoefent de psychologische behoefte om een beroep te kunnen doen op personen op wie hij onvoorwaardelijk kan vertrouwen en op wier loyauteit en volstrekte discretie hij kan rekenen. ${ }^{324}$ Daarnaast is er een meer institutionele reden: de Koning heeft het recht en de plicht zich een eigen oordeel te vormen over de uitoefening van zijn taken. ${ }^{325}$ Hij moet daarbij beroep kunnen doen op medewerkers die zijn vertrouwen hebben. Ministeriële verantwoordelijkheid zou tot gevolg kunnen hebben dat de eerste minister aan de Koning medewerkers opdringt en dat de koninklijke functie door de regering wordt ingepalmd. Het zou de medewerkers van de Koning kunnen afhankelijk maken van de regering. ${ }^{326}$ Het zou ook tot gevolg kunnen hebben dat het Huis van de Koning bij de wisseling van de regering wordt gewijzigd. Dit zou de continuïteit van het optreden van de Koning in het gedrang brengen en ook ingaan tegen de idee dat het staatshoofd de tegenstellingen tussen de partijen, tussen de meerderheid en de minderheid overstijgt.

-97. Het staatshoofd mag dan al vrij zijn medewerkers te kiezen, het is ook gebruikelijk zoals de commissie-Soenens het uitdrukte dat men de ministers 'die bescheiden geraadpleegd werden, de mogelijkheid laat de redenen te doen kennen voor dewelke

32I Het Huis van de Koning bestaat thans uitzes autonome departementen. De departementshoofden samen vormen het Directiecomité van het Hof. Het bestaat uit de Kabinetschef van de Koning, de Intendant van de Civiele lijst, het Hoofd van het Militair Huis, de Protocolchef, het Hoofd van het Departement Buitenlandse Betrekkingen en het Hoofd van het Departement Rekwesten en Sociale Zaken.

322 P. De Visscher, 'La Fonction royale', Rev. Gen. B., I949, 698.

323 A. Molitor, La fonction royale en Belgique, p. I58.

324 Met De Visscher kan men dan ook stellen dat het Kabinet van de Koning 'relève du domaine privé; l'on pourrait même dire, du domaine sentimental et affectif. En effet, la justification première de la fonction réside dans ce besoin naturel qui existe chez tout individu d'avoir à ses côtés un homme de confiance.' C. De Visscher, 'Le Cabinet du Roi', Ann. Dr., I950, p. I70.

325 In het Verslag van de Commissie-Soenens uit 1949 lezen we hierover: 'In de uitoefening van de machten welke hem door de Grondwet toegekend worden, heeft de Koning niet alleen het recht maar tevens de plicht zich een persoonlijke opvatting te vormen over de zaken die hem voorgelegd worden. Te dien einde moet de Koning ingelicht en voorgelicht worden. Indien zulks slechts geschiedde door de bemiddeling van zijn ministers, die zijn enige verantwoordelijke raadgevers zijn, maar die schier altijd een fractie van de politieke opvatting vertegenwoordigen, zou de koninklijke functie het gevaar lopen opgeslorpt te worden door de ministeriële functie en zou de Koning slechts moeilijk zijn hoge zending van verzoener der partijen kunnen volbrengen. Daarom moet de Koning het advies kunnen inwinnen van private medewerkers die in de politieke strijd niet betrokken zijn.' Zie ook A. Molitor, La fonction royale en Belgique, p. I37.

326 A. Van Welkenhuyzen, $V^{\circ}$ Chef de l'Etat, R.P.D.B., I977, Compl. V., n 58. 
een bepaalde benoeming hun ongepast zou schijnen.' Ook zij zullen immers intensief met die medewerkers moeten samenwerken. Een onoordeelkundige keuze kan zowel het aanzien van de monarchie schade berokkenen als de goede werking van de instellingen hypothekeren. ${ }^{327} \mathrm{Zij}$ kunnen dus hun bedenkingen overmaken. De Koning kan ermee rekening houden, maar is daar niet toe verplicht.

In het verleden is het voorgekomen dat ingevolge het 'discreet advies' van de regering bepaalde personen niet in het Kabinet van de Koning zijn opgenomen. Enige jaren geleden is de Koning echter niet ingegaan op de nauwelijks verholen openlijke suggestie vanuit de regering om de kabinetschef van de Koning, de h. van Yperseele de Strihou, die reeds sinds 1984 in dienst is, te vervangen. ${ }^{228}$ Daarover ondervraagd in een Kamercommissie bevestigde de eerste minister de grondwettelijke gewoonte: 'De koning kiest en benoemt vrij zijn medewerkers. Het is mijn intentie, net als die van de regering die ik leid, het hierbij te laten.' De premier stelde nog dat er geen duurtijd voor die medewerkers wordt bepaald en dat de koning daar zelf over beslist: 'De regering komt daar niet in tussen, er is zelfs geen ministeriële medeondertekening. (...) En ik ben niet van plan dat in de toekomst te veranderen. ${ }^{329}$

-98. De grondwettelijke gewoonte houdt een subtiel evenwicht in tussen de vrijheid van de Koning om zijn medewerkers te kiezen en de erkenning dat ook de ministers belang hebben bij die keuze. Ze leidt ertoe dat de regering terughoudend zal blijven omdat ze weet dat het gaat om de persoonlijke medewerkers van de Koning en dat de ministeriële verantwoordelijkheid ter zake niet geldt, doch dat de Koning de negatieve bedenkingen in overweging kan nemen die de regering desgevallend uit, zonder er evenwel door gebonden te zijn..$^{3{ }^{\circ}}$ Het Belgische staatsrecht verschilt hier dus van het Nederlandse dat inhoudt dat de minister-president in overeenstemming met de minister van binnenlandse zaken en Koninkrijksrelaties verantwoordelijk is voor de benoeming en het ontslag van de directeur van het Kabinet van de Koning. ${ }^{331}$ Het Belgische staatsrecht gaat ook minder ver dan het Britse waar de private secretary weliswaar door de Koning wordt benoemd maar ook voor de prime minister aanvaardbaar moet zijn. Dit wordt op typische Britse wijze tot uiting gebracht doordat de koningin hem de Royal Victorian Order verleent, wat haar persoonlijk privilegie

327 Ch. De Visscher, 'La Fonction royale', 698; zie ook L. De Lichtervelde, 'Coutumes de la Monarchie constitutionnelle', o.c., p. 156 en v.; P. De Visscher, 'La Fonction royale', Rev. Gen. B., I949, p. 698.

328 Vice-eerste minister Vande Lanotte stelde op 8 december 1999 in het VTM-programma 'Schaduwkabinet' over de kabinetschef van de Koning, dat 'geen enkele functie eeuwig kan duren, ook niet die van kabinetschef van de koning.' Daags nadien reageerde de eerste minister Verhofstadt kort als volgt: 'Wat hij zegt, lijkt me helemaal evident, maar ik wil daar verder geen verklaringen over afleggen.'

329 Antwoord op de mondelinge vraag van de h. Tastenhoye aan de eerste minister over 'de verklaringen van de vice-eerste minister en minister van Begroting, Maatschappelijke Integratie en Sociale Economie met betrekking tot de kabinetschef van de Koning. Parl. St., Kamer, I9992000, HA 50 COM 079, p. I6 en v. 9.

330 Ganshof vander Meersch schrijft : 'Celui-ci (le Roi) toutefois ne pourrait pas ne pas consulter ou ne pas tenir compte des objections qu'ils pourraient lui présenter.' W.J. Ganshof van der Meersch, 'Des rapports entre le chef de l'Etat et le gouvernement en droit constitutionnel belge', Rev. dr. Int. dr. comp., nr. spec., I950, p. I94.

33 Art. 2 Besluit van I8 december 2003 houdende bepalingen over het Kabinet van de Koning. 
is, en een knighthood in the Order of the Bath wat ze on advice van de eerste minister doet. ${ }^{332}$

\section{B Het optreden van de medewerkers van de Koning}

-99. De persoonlijke medewerkers zijn in beginsel slechts aan de Koning zelf verantwoording verschuldigd voor de wijze waarop zij hun functie uitoefenen. 333 De ministers kunnen hun geen instructies geven en kunnen voor hun optreden ook niet ter verantwoording worden geroepen in de Kamer. ${ }^{334}$ Soms wordt beweerd dat er hier van een democratisch deficit sprake is. In een democratie moet het geheel van het overheidsoptreden immers door de volksvertegenwoordiging kunnen worden gecontroleerd en gestuurd. De leden van het Huis van de Koning lijken daaraan te ontsnappen. De afwezigheid van ministeriële verantwoordelijkheid wordt veelal verantwoord door erop te wijzen dat de medewerkers van de Koning niet tot het overheidsapparaat behoren: zij hebben geen eigen bevoegdheden en oefenen geen enkele overheidsmacht uit, waarvoor de ministeriële verantwoordelijkheid zou moeten gelden. Zij zijn slechts de persoonlijke private medewerkers van de Koning, die hem informeren en adviseren. Omdat de ministers geen enkele zeggenschap over hen hebben, kunnen ze ook niet verantwoordelijk zijn. Immers: 'Geen verantwoordelijkheid zonder bevoegdheid.'

-Iоo. Men kan inderdaad stellen dat de medewerkers van de Koning in beginsel slechts private personen zijn, die niet als overheden kunnen worden beschouwd. In de mate dat zij het staatshoofd slechts adviseren, hem informeren en bijstaan en door allerhande ontmoetingen en contacten, ten behoeve van het staatshoofd, pogen op de hoogte te blijven van het politieke reilen en zeilen in het land, oefenen zij geen overheidstaken uit. Zeer uitzonderlijk treden leden van het Huis van de Koning echter wel namens de Koning zelf op, met rechtsgevolgen. Zo treedt de intendant van de civiele lijst in rechte op, als eiser of verweerder, wanneer het vermogen van de Koning in het geding is. ${ }^{335} \mathrm{Hij}$ zal bv. ook het klachtrecht uitoefenen inzake jachtmisdrijven en zich burgerlijke partij stellen..$^{336}$ De intendant treedt op qualitate qua, op zo'n wijze dat de Koning zelfs niet als mandataris in het geding voorkomt. ${ }^{337}$ Omdat zijn optreden dan bezwaarlijk als dat van een louter private medewerker kan worden beschouwd en omdat het daarenboven niet alleen een weerslag kan hebben op het vermogen van de Koning, doch ook op het aanzien van het Staatshoofd en van de dynastie, is het o.i. moeilijk denkbaar dat de ministeriële verantwoordelijkheid

332 V. Bogdanor, The monarchy and the constitution, p. 201.

333 A. Molitor, La fonction royale en Belgique, p. I35.

334 A. Molitor, La fonction royale en Belgique, p. I35; Advies Alen, o.c., p. 292.

335 Artikel 4I van het Gerechtelijk Wetboek bepaalt thans: 'Iedere betekening ten aanzien van de Koning met betrekking tot zijn domeinen wordt gedaan aan de persoon en aan het kabinet van de intendant of van de administrateur van de civiele lijst.' 20/I, p. 902, nr. I4 en I5.

336 P. Schuermans, 'Le Roi en Justice', B.J., I895, p. 4I8-4I9.

337 S. Wiener, 'Observations' bij Rb. Dinant, 6 december I894, Les comtes de Cunchy c. le baron Goffinet, intendant de la liste civile et administrateur du domaine privé du Roi, et c. la Caisse hypothécaire Anversoise, BJ, I895, p. I74-I8o. 
hier niet zou gelden. Daarenboven dient ook melding te worden gemaakt van het Koninklijk Besluit van I6 oktober 2002 dat aan bepaalde diensten van het Koninklijk Paleis toegang verleent tot het Rijksregister van de natuurlijke personen. ${ }^{33^{8}}$ In beginsel kan zo'n toegang alleen worden verleend aan een openbare overheid zoals bedoeld in artikel 5 , eerste lid, van de wet van 8 augustus I $_{9} 83$ tot regeling van een Rijksregister van de natuurlijke personen. In het Verslag aan de Koning dat aan het K.B. voorafgaat wordt geargumenteerd dat 'de Koning, als Staatshoofd, onder de verantwoordelijkheid van de Ministers, niet enkel belast is met de uitvoering van de wetten maar ook met het algemeen beleid van het land en met het beheer van de diensten van de Staat' en dat hij derhalve dient beschouwd te worden als een openbare overheid. Het K.B. geeft evenwel niet rechtstreeks aan de Koning zelf toegang doch wel aan een aantal hofdignitarissen. ${ }^{339}$ Het bepaalt, welke informatie ze kunnen opvragen ${ }^{340}$ en voor de uitoefening van welke taken. ${ }^{34 \mathrm{I}}$ Volgens het Verslag aan de Koning gaat het om de taken die inherent zijn aan de uitoefening van de koninklijke functie overeenkomstig het grondwettelijk gewoonterecht. Wanneer de diensten van de Koning van de bevoegdheid om het Rijksregister te consulteren gebruik maken is de ministeriële verantwoordelijkheid o.i. eveneens in het geding. Ze hebben die bevoegdheid dan immers slechts omdat ze voor de Koning optreden. Dat de ministeriële verantwoordelijkheid hier wenselijk is, blijkt trouwens uit de zogenoemde Margarita-affaire die in 2003 in Nederland voor heel wat opschudding zorgde.

-IoI. In België wordt tot op heden niet aanvaard dat de verantwoordelijkheid van de regering voor het algemeen belang en dus ook voor het aanzien van de monarchie onrechtstreeks een verantwoordelijkheid voor het optreden van de medewerkers van de Koning tot gevolg heeft. In het verleden is weliswaar gebleken dat de gesprekken die een medewerker van de Koning voert en de ontmoetingen die hij heeft, de monarchie in opspraak kunnen brengen. ${ }^{342}$ De onschendbaarheid van het staatshoofd is dan in het geding. Omdat het echter strijdig wordt geacht met de constitutionele beginselen over de monarchie dat de persoonlijke medewerkers

338 K.B. I6 oktober 2002 waarbij aan bepaalde diensten van het Koninklijk Paleis toegang wordt verleend tot het Rijksregister van de natuurlijke personen, B.S., 23 januari 2002.

339 De toegang tot de informatiegegevens is voorbehouden voor de volgende dignitarissen: $I^{\circ}$ (a) de Grootmaarschalk van het Hof; (b) de Kabinetschef van de Koning; (c) het Hoofd van het Militair Huis van de Koning; (d) de Grootmeester van het Huis van Koningin Fabiola; (e) de Adviseur van Prins Filip en $2^{\circ}$ de personeelsleden die deze dignitarissen met dit doel bij naam en schriftelijk aanwijzen, wegens hun functie en binnen de perken van hun respectieve bevoegdheden.

340 Naam en voornaam, geboorteplaats- en datum, geslacht, hoofdverblijfplaats, plaats en datum van overlijden, burgerlijke staat, samenstelling van het gezin.

34I Het gaat meer bepaald om $\mathrm{I}^{\circ}$ de behandeling van verzoekschriften gericht tot de Vorsten of Leden van de Koninklijke Familie; $2^{\circ}$ de gelukwensen van de Vorsten aan jubilarissen; $3^{\circ}$ het toesturen van de antwoorden op de blijken van gehechtheid aan de Vorsten of op de gelukwensen gericht tot de Vorsten of Leden van de Koninklijke Familie; $4^{\circ}$ het bijhouden van adressenbestanden van alle personen die in contact komen met het Hof in het kader van de verschillende activiteiten waar de Vorsten of Leden van de Koninklijke Familie bij betrokken zijn.

342 Zie bv. de commotie veroorzaakt door het optreden van de secretaris van Koning Albert I, Jules Ingenbleek, voor de Eerste Wereldoorlog en door het optreden van de secretaris van koning Leopold III, graaf Robert Capelle, tijdens de Tweede Wereldoorlog. 
van de koning op enigerlei wijze van de ministers afhankelijk zouden zijn, wordt elke ministeriële verantwoordelijkheid ter zake verworpen. Het Belgisch staatsrecht verkiest uit te gaan van het adagium 'het is beter te voorkomen dan te genezen.' Vandaar dat zwaar wordt ingezet op de deontologie van die persoonlijke medewerkers van de Koning. Van hen wordt verwacht dat ze de onschendbaarheid van de Koning niet in het gedrang brengen. Zij zijn tot strikte geheimhouding verplicht over alles wat ze in de uitoefening van hun functie vernemen en wat tot een ontbloting van de Kroon zou kunnen leiden indien ze het zouden onthullen. Ze zijn ook tot discretie verplicht. Zij dienen zich steeds ervan bewust te zijn dat zij als een 'verlengstuk' van de Koning worden beschouwd. Velen gaan er immers van uit dat als zij zich uiten, zij de zienswijze van het Hof weergeven en dat zij in staat zijn invloed uit te oefenen op de Koning en daardoor ook op de regering. ${ }^{343}$ De commissie-Soenens stelde: 'In het vervullen van deze zending moeten de leden van het Kabinet van de koning zich op de achtergrond houden en blijk geven van een absolute bescheidenheid.' De medewerkers van de Koning mogen zich dan ook niet laten verleiden om zich in het openbaar uit te laten over actuele politieke kwesties of over controversiële onderwerpen. Om niet de indruk te wekken dat bepaalde personen of groepen in de samenleving een bevoorrechte relatie onderhouden met het Hof, is ook elk lidmaatschap van politieke partijen of belangengroepen uit den boze.

-I02. Deze deontologische regels hebben ook uitlopers in de rechtspraak. Zo heeft de Raad van State in een arrest van 8 juni rg6r geoordeeld dat het niet toegelaten is in een procedure over de geldigheid van een benoemingsbesluit, uitlatingen van een medewerker van de Koning aan te voeren om te bewijzen dat het besluit door machtsafwending is aangetast. In casu zou een medewerker van de Koning hebben verklaard dat een kandidaat niet benoemd was omdat hij 'door Hofkringen zeer werd veracht wegens zijn bedenkelijke rol in de Koningskwestie.' Uit het arrest blijkt dat de Raad van State om twee redenen met die uitlatingen weigert rekening te houden. ${ }^{344}$ In de eerste plaats omdat het de medewerkers niet toekomt de persoonlijke mening van de Koning bekend te maken, en vervolgens ook omdat alleen de motieven van de minister relevant zijn om een eventuele machtsafwending te beoordelen. De Raad beklemtoont immers 'dat de Minister de enige is die grondwettelijk verantwoordelijk is voor de daden van de Koning.'

-I03. Ook parlementaire onderzoekscommissies hebben niet het recht aan de medewerkers van de Koning vragen te stellen die onvermijdelijk tot een aantasting van de koninklijke onschendbaarheid zullen leiden. Die kwestie was aan de orde in de zogenoemde Rwanda-commissie van de Senaat die in het midden van de jaren negentig

343 A. Molitor, La fonction royale en Belgique, p. I63-I64.

344 R.v.St., 8 juni I96I, Leloup t. B.S., nr. 8649, 8 juni r96r 'Overwegende dat de Minister de enige is die grondwettelijk verantwoordelijk is voor de daden van de Koning; dat uitlatingen, toegeschreven aan personen die geacht worden 's Konings persoonlijke mening te kennen maar niet bevoegd zijn om deze te verkondigen alleen die personen binden; dat die uitlatingen zelfs al waren ze bewezen niet vermogen aan te tonen dat er machtsafwending is; dat het aanbod het bewijs van die feiten te leveren niet in aanmerking kan worden genomen.' 
werd opgericht Uit de voorbereidingen van deze commissie was gebleken dat er ten tijde van het drama vermoedelijk informatie was overgemaakt aan de kabinetschef van de Koning en wellicht ook aan het hoofd van het Militair Huis. Er rezen vele vragen. Welke rol had het Huis van de Koning precies gespeeld? Was de informatie overgemaakt aan de Koning en had ze van daaruit ook de ministers bereikt? Een aantal senatoren drongen erop aan de kabinetschef en het Hoofd van het Militair Huis te horen. Over dit verzoek won de voorzitter van de Senaat het advies in van de constitutionalisten A. Alen en J.C. Scholsem en van de juridische dienst van de Senaat. Allen oordeelden dat zowel de onschendbaarheid van de koning als de eenheid van de Kroon er zich tegen verzette dat de persoonlijke medewerkers van de koning door de commissie werden ondervraagd 345 Volgens Alen 'zou hun ondervraging (...) in feite neerkomen op een ondervraging van de Koning zelf, hetgeen vanzelfsprekend niet mogelijk is, gelet op zijn absolute onschendbaarheid. Bovendien zou dergelijke ondervraging nog andere grondwettelijke beginselen schenden, met name de eenheid tussen de Koning en de Regering en het hiermee samenhangend verbod om het aandeel van de Koning in de onder de verantwoordelijkheid der ministers genomen beslissingen te kennen. ${ }^{346}$ Vanzelfsprekend geldt dit slechts als het onderzoek betrekking heeft op 'de uitoefening van zijn functie', ${ }^{347}$ niet als het onderzoek daar niets mee te maken heeft. Indien een onderzoekscommissie van oordeel is dat hij de medewerker van de Koning wel kan ondervragen, dan zal deze o.i. niet kunnen weigeren om op die uitnodiging in te gaan. Hij zal evenmin kunnen weigeren de eed af te leggen..$^{34} \mathrm{Hij}$ heeft echter wel het recht en de plicht ${ }^{349}$ om te weigeren om te antwoorden, wanneer hij daardoor de hiervoor vermelde constitutionele beginselen zou schenden.

\section{De financiële aspecten van het koningschap: de civiele lijst en de dotaties van de leden van de koninklijke familie}

-I04. Ten slotte weze nog vermeld dat de bepaling in de grondwet over de financiële aspecten van het koningschap er eveneens op gericht is de koning op dat vlak voldoende ruimte te laten. Artikel 89 van de Belgische grondwet bepaalt: 'De civiele lijst wordt door de wet vastgesteld voor de duur van de regering van elke koning.'

345 Zie A. Alen, J.C. Scholsem en Dienst Juridische Zaken van de Senaat, 'Kan een parlementaire commissie leden van het kabinet van de Koning ondervragen?', T.B.P., I997, p. 29I-296; zie ook Parl. St., Senaat, 1997-1998, nr. I-6ri/ro.

346 Advies A. Alen, o.c., p. 292.

347 A. Alen heeft het in zijn advies over een ondervraging over 'politieke beleidsbeslissingen'; Scholsem beperkt zich tot de 'feiten die te maken hebben met de uitoefening van hun specifieke functies'. In de nota van de juridische dienst, wordt terecht gesteld: 'De zaak ligt anders wanneer een medewerker van de Koning opgeroepen wordt om verhoord te worden over een kwestie die totaal vreemd is aan de uitoefening van zijn ambt in het kabinet van de Koning; als specialist in een of andere aangelegenheid, wegens een vroeger uitgeoefend ambt.'.

348 Zie in dezelfde zin i.v.m. personen die zich op een beroepsgeheim kunnen beroepen. M. Van der Hulst, Het federale parlement, Organisatie en werking, UGA, 20Io, p. 472, nr. 879.

349 De medewerkers van de Koning zijn hier in dezelfde positie als degenen die verplicht zijn tot geheimhouding zoals bv. magistraten die het geheim van de beraadslaging niet mogen schenden. Zie daarover Cass. 27 januari 2007, J.L.M.B., 2007, 28I. 
Het impliceert dat de wetgever verplicht is bij het begin van de regeerperiode de middelen te bepalen waarover de Koning zal kunnen beschikken om zijn ambt uit te oefenen en dat deze middelen tijdens de regeerperiode niet meer kunnen worden gewijzigd. Het artikel houdt aldus een dubbele waarborg in: de civiele lijst heeft een forfaitair karakter (A) en is onveranderlijk (B). In het verleden is er over het gebrek aan transparantie van de civiele lijst discussie gerezen (C).

\section{A Het forfaitair karakter van de civiele lijst}

-I05. Het begrip 'civiele lijst', in de zin van artikel 89 van de grondwet, slaat op het geheel van de middelen die door de wetgever aan de Koning bij het begin van zijn regeerperiode worden toegekend, om hem toe te laten op een waardige wijze zijn ambt uit te oefenen..$^{50}$ De grondwet houdt geen aanwijzingen in over de omvang van de Civiele Lijst. De wetgever bepaalt die vrij. Traditioneel legt de wet een bedrag vast en stelt een aantal goederen die tot het Kroondomein behoren ter beschikking van de Koning. Zo werd de civiele lijst van Koning Albert bij wet van I6 november $1993^{351}$ op 244.000 .000 fr. (6.048.602 euro) vastgesteld, werden hem het Koninklijk Paleis te Brussel en het Kasteel van Laken ter beschikking gesteld ${ }^{352}$ en werd een regeling uitgewerkt voor de onderhoudskosten. ${ }^{353}$ De Civiele lijst is noch een inkomen, noch een schenking. Er zijn dan ook geen inkomstenbelastingen of schenkingsrechten verschuldigd. ${ }^{354} \mathrm{Ze}$ heeft het statuut van een dotatie. Een dotatie is een krediet dat is opgenomen in de begroting maar waarvan de besteding wordt geregeld door de instelling waaraan het wordt verleend. ${ }^{355}$ De civiele lijst is een dotatie die ter beschikking van de Koning wordt gesteld om in de uitgaven van zijn ambt te voorzien. ${ }^{356} \mathrm{Het}$ is met andere woorden een forfaitaire vergoeding die de Koning moet toelaten zijn taken als staatshoofd naar behoren uit te oefenen. ${ }^{357}$ Op een regeringswebsite wordt de civiele lijst een 'institutioneel budget' genoemd 'waarmee de Koning zijn medewerkers vergoedt, de koninklijke residenties onderhoudt, zijn persoonlijke uitgaven

350 J. Vanwelkenhuyzen, R.P.D.B., V Chef de l'Etat, Compl. V, I977, p. 237, nr. 9.

35I Wet van I6 november 1993 houdende vaststelling van de Civiele Lijst voor de duur van de regering van Koning Albert II, tot toekenning van een jaarlijkse en levenslange dotatie aan Hare Majesteit Koningin Fabiola en van een jaarlijkse dotatie aan Zijne Koninklijke Hoogheid Prins Filip, B.S., 29 maart 1994 .

352 Daarnaast worden aan de Koninklijke familie ook eigendommen van de Koninklijke Schenking ter beschikking gesteld. Het gaat om goederen die Leopold II ruim een eeuw geleden aan de staat heeft geschonken en die werden ondergebracht in een zelfstandige openbare instelling. We gaan er hier niet nader op in. Zie K. Stangherlin, Le patrimoine royale, La Charte, 2004, p. 32-59.

353 Het extern onderhoud van het Paleis te Brussel en het Kasteel te Laken, alsook de verwarmingskosten van het Paleis te Brussel, vallen ten laste van de Staat.

354 Parl. St., Senaat, I993-I994, 860/2, p. 3 (minister van Financiën).

355 Advies Raad van State, 39.894/4, Parl. St.,Senaat, BZ 2005-2006, nr. 3-1060/6.

356 Molitor schrijft: 'La Liste civile, par contre, est une dotation forfaitaire de droit public accordée au Roi par la Nation pour faire face à ses obligations de Chef de l'Etat.' o.c., I73. Zie ook K. Stangherlin, Le patrimoine royale, La Charte, 2004, p. 67.

357 Parl. Hand., Kamer, I993-I994, I2 oktober I993, p. 23 (vice-premier Van Rompuy). 'La liste civile est en réalité, pour le Souverain un budget de dépenses analogue aux budgets ministériels; elle n'a ni le caractère d'une libéralité, ni celui d'une indemnité, ni celui d'une rémunération. Memorie van toelichting bij het ontwerp dat de wet van 27 juli 1927 is geworden, Pasin, I927, p. $304(\mathrm{Ned})$. 
dekt, alsook de onthaal- en representatiekosten. ${ }^{35^{8}}$ Eventuele overschotten worden overgedragen naar het volgende begrotingsjaar. Er gebeurt geen overdracht naar het privévermogen van de Koning. 359

\section{B De onveranderlijkheid van de civiele lijst}

-Io6. Uit artikel 89 van de grondwet volgt dat de civiele lijst bij het begin van de regeerperiode moet worden vastgesteld en heel de regeerperiode onveranderlijk moet blijven. Het Nationaal Congres had daarmee een dubbel doel. De grondwetgever wilde de wederzijdse onafhankelijkheid van de Koning en het parlement waarborgen. ${ }^{360}$ Hij wilde voorkomen dat de Koning jaarlijks bij het parlement zou moeten aankloppen om zijn dotatie veilig te stellen, maar ook dat hij jaarlijks het parlement onder druk zou kunnen zetten om de dotatie te verhogen. ${ }^{6 r}$ Daarenboven wilde de grondwetgever verhinderen dat er jaarlijks in het parlement over de middelen van de Koning discussie zou ontstaan, waarbij ook de monarchie zelf of haar actuele invulling zou worden betwist. ${ }^{362}$ Om te vermijden dat er jaarlijks een dergelijk debat zou plaats vinden, overwoog het Nationaal Congres aanvankelijk om het bedrag van de civiele lijst in de grondwet zelf in te schrijven. ${ }^{363}$ Uiteindelijk werd er voor geopteerd het aan de wetgever over te laten om bij het begin van de regeerperiode van elke koning de civiele lijst te bepalen. Jaarlijks dient dat bedrag dan in de begroting voor dotaties te worden ingeschreven. Tussentijdse verhogingen of verlagingen zijn strijdig met de grondwet. Met de ratio legis van artikel 89 van de grondwet is het evenwel niet strijdig dat het nominale bedrag van de civiele lijst bij muntontwaarding wordt aangepast. Het beginsel van de onveranderlijkheid impliceert immers dat de waarde van de civiele lijst gedurende de hele regeerperiode gelijk blijft. Om de muntontwaarding te compenseren werden in het verleden verschillende technieken aangewend. Een eerste aanpassing gebeurde in 1927. Door een devaluatie in 1926 was de Belgische frank tot $\mathrm{I} / 7$ van haar waarde gedaald. In een interpretatieve wet van 23 juli $1927^{364}$ werd dit gedeeltelijk gecompenseerd door te bepalen dat de 3.300.000 franken die in 1909 waren toegekend, overeenstemden met 9.500.000 franken uit I927. Tijdens de regeerperiode van Koning Boudewijn werd de civiele lijst door een

358 www.belgium.be/nl/over_belgie/overheid/federale_overheid/koning/symbolische_rol.

359 P.Y. Monette, Métier de Roi de A à Z, p. I05 (Liste civile du Roi).

360 Zie Parl. St., Senaat, I992-I993, nr. II55/3, p. 2.

36I Zie het verslag van de Senaatscommissie bij het ontwerp dat de wet van 23 juli ig27 betreffende de civiele lijst (B.S., 29 juli 1927) is geworden: 'Dit voorschrift heeft voor doel te vermijden dat volgens de gelegenheid en den stand der politieke machten de Vorst en het Parlement van hunnen invloed zouden misbruik maken, de eene om een verhooging van de Civiele Lijst te verkrijgen, de andere om ze te verminderen of ze afhankelijk te stellen aan voorwaarden van de stemming der noodige credieten. Elk gevaar moet vermeden worden aldus op bepaalde tijdstippen pijnlijke debatten en tusschen de Kroon en de Kamers een band van ondergeschiktheid te zien ontstaan die de miskenning ware van een fundamenteel beginsel van de parlementaire monarchie, namelijk het evenwicht der machten.' Parl. St., Senaat, I926-I927, nr. 202, p. 5 .

362 R. Senelle en E. Clement, Dotaties, Die Keure, I990, p. 4.

363 E. Huyttens, Discussions de Congrès National de Belgique, I830-I83I, IV, p. 85.

364 Wet 23 juli ig27 over de civiele lijst, B.S., 29 juli 1927. 
interpretatieve wet van 26 januari $1965^{365}$ aan de index van de consumptieprijzen gekoppeld. De civiele lijst van Koning Albert II ten slotte werd van meet af aan de index van de consumptieprijzen gekoppeld. Daarenboven werd bepaald dat het bedrag driejaarlijks zou worden geherwaardeerd op grond van de evolutie van de reële lonen van de diensten van het algemeen bestuur van de Federale Staat en van de toename van de werkgeversbijdragen inzake sociale zekerheid. ${ }^{366} \mathrm{Al}$ deze aanpassingen werden onontbeerlijk geacht om de waarde van de civiele lijst op peil te houden. In $201 \mathrm{I}$ is de civiele lijst van Albert daardoor opgelopen tot bijna Io,7 miljoen euro. Dat de onveranderlijkheid van de civiele lijst in onze tijd soms als hinderlijk wordt ervaren moge blijken uit de merkwaardige constructie die recent werd opgezet. Om in tijden van matiging de verhoging van de civiele lijst ingevolge indexatie te compenseren, werden de dotaties van de overige leden van de koninklijke familie verminderd. ${ }^{367}$ Zo kon ook de Koninklijke familie haar steentje bijdragen in de besparingen van de overheid.

\section{Transparantie en democratische controle op de aanwending van de civiele lijst}

-I07. De aanwending van de civiele lijst valt in beginsel niet onder de ministeriële verantwoordelijkheid en staat niet onder parlementaire controle. Ook het Rekenhof oefent geen toezicht uit. De Koning besteedt de gelden van de civiele lijst zonder dat hij daarover verantwoording heeft af te leggen. ${ }^{368}$ Zelfs tot mededelingen over de gedane uitgaven is het Hof niet verplicht. Al vele jaren wordt wel op vrijwillige basis, onder verantwoordelijkheid van de regering, informatie verstrekt over de globale percentages van uitgaven die met de civiele lijst worden gefinancierd..$^{36}$

-ro8. De constitutionele regeling over de financiële aspecten van het koningschap was al vaak voorwerp van kritiek, zowel in het parlement als in de media. De regeling werd in 183 I uitgedacht en kwam tegemoet aan bekommernissen die in de negentiende eeuw leefden. Vandaag lijkt ze echter niet meer te voldoen aan de eisen die in de eenentwintigste eeuw aan het beheer van overheidsfinanciën worden gesteld. Er worden drie types van kritieken geformuleerd. In de eerste plaats wordt betreurd dat de regering niet op een meer transparante en controleerbare wijze verantwoording aflegt over het gebruik van de middelen die aan de monarchie

365 B.S., 3 februari 1965 .

366 Art. 4 en 5 wet 6 september 1993 . De wet van 29 december 2008 heeft de driejaarlijkse aanpassing afgeschaft en de evolutie van de civiele lijst aan de gezondheidsindex gekoppeld en niet meer aan het indexcijfer van de consumptieprijzen.

367 Zie Parl. St., Kamer, 2009-2010, Doc. 52 2285/2, p. 3.

368 A. Mast en J. Dujardin, Overzicht van het Belgisch grondwettelijk recht, 7de druk, Gent, Story Scientia, I983, p. 287; H. Matthijs, D. Matthijs en S. Mergaerts, Overheidsbegrotingen, t. I, Brugge, Die Keure, 2002, p. I6o; K. Stangherlin, Le patrimoine royale, La Charte, 2004, p. 67.

369 De website van de Monarchie splitst de uitgaven over de jaren I995 tot 2007 als volgt uit: 'Personeelsuitgaven: $66 \%$; onderhoud van domeinen en meubilair: I2,5\%; activiteiten, bezoeken: 5,5\%; verwarming, gas, elektriciteit, water: $4,9 \%$; werking van de administratie: 2,6\%; huishoudelijke uitgaven: I,6\%; autopark 4,5\%; allerlei: I, $8 \%$, www.monarchie.be/nl/ de-monarchie-vandaag/middelen\#liste. 
ter beschikking worden gesteld. De enkele gegevens die door het Hof op de website worden gepubliceerd zijn inderdaad te elementair om ze als een verantwoording te beschouwen. Meer precieze staten met de uitgaven van de civiele lijst ontbreken. Hierover is al vaker ongenoegen geuit. Vervolgens wordt benadrukt dat alhoewel de civiele lijst alle uitgaven verbonden aan het koningschap zou moeten dekken, er nog steeds heel wat uitgaven ten laste van andere begrotingen worden gelegd, wat op gespannen voet staat met artikel 89 van de grondwet. Het gaat o.m. om lonen van gedetacheerde ambtenaren die soms op de loonlijst van hun overheidsdienst blijven staan, om de kosten van het veiligheidsdetachement van het Paleis dat onder de federale politie valt, om de verplaatsingskosten met vliegtuigen van de luchtmacht, om vrijstellingen, zoals portvrijdom of vrijstelling van btw op brandstof voor het wagenpark enz. Ten slotte wordt soms ook gehekeld dat het onderscheid tussen de persoonlijke uitgaven van de Koning, die ten laste van de civiele lijst kunnen worden gelegd, en deze die ten laste van het private vermogen van de koning moeten blijven, onvoldoende scherp is en dat daarenboven het statuut van de roerende goederen die de Koning met middelen van de civiele lijst aankoopt - het halssnoer voor de koningin of het schilderij dat voor een ontvangstsalon in het kasteel is bestemd - niet zo duidelijk is. Behoren ze tot het Kroondomein, zodat ze eigendom zijn van de Staat, of behoren ze tot het privaatvermogen van de koning? Op het ogenblik dat de nalatenschap moet worden verdeeld en de aangifte voor de successiebelastingen moet worden opgesteld zijn er in het verleden daarover al vaak betwistingen gerezen..$^{370}$ Meer duidelijkheid over het roerend vermogen van de Koning zou geen overbodige luxe zijn. ${ }^{371}$

370 Derème schrijft hierover: 'Des droits de succession ont-ils dû être payés lors du décès du Roi Baudouin sur les biens meubles acquis par le Roi au cours d'un règne long de 40 ans et accumulés au Palais de Bruxelles ainsi qu'au Château de Laeken? Objets d'art, limousines de cérémonie, ordinateurs, télévisions, meubles meublants... font-ils partie de la succession du Roi et sont-ils soumis aux droits de succession? Devraient-ils être pris en compte pour le calcul de la masse successorale, de la réserve et de la quotité disponible éventuelles? Vu qu'aucune solution claire et précise n'a jamais été dégagée, il semble que les successions royales aient toujours été réglées par voie d'un compromis, fruit de discussions entre le ministre des Finances, le Premier ministre, l'Intendant de la Liste civile, le Chef de Cabinet du Roi.' F. Derème, 'Le régime juridique des biens du Roi', Rev. Not., 2000, p. 76. Zie ook K. Stangherlin, Le patrimoine royale, La Charte, 2004, p. 90-94.

37 I De lege late, stelt Derème voor uit te gaan van het onderscheid publiek en privaat domein. De door de Koning, met gelden van de civiele lijst, aangekochte roerende goederen die een publieke bestemming hebben gekregen, in het kader van de uitoefening van de koninklijke functie, zouden tot het Kroondomein en dus tot het eigendom van de Staat behoren. Om de problemen die kunnen rijzen bij de toepassing van de criteria in de grijze zone tussen publiek en privaat, zou men kunnen uitgaan van een weerlegbaar vermoeden dat de goederen behoren tot het Kroondomein. De lege ferenda suggereert Derème de oprichting, bij wet, van een 'Kroonpatrimonium', een instelling met rechtspersoonlijkheid die zoals een 'Trust' of een 'Fiduciaire', eigenaar zou worden van het Kroondomein en ook van alle goederen die voor de uitoefening van de koninklijke functie zijn bestemd. F. Derème, 'Le régime juridique des biens du Roi', Rev. Not., 2000, p. 62-8I. 
-rog. De hele discussie stelt de ambiguïteit van de civiele lijst in het licht. ${ }^{372}$ Weliswaar wordt erop gewezen dat het nu eenmaal wezenlijk is voor het koningschap dat persoon en instelling onlosmakelijk verbonden zijn en dat het dus moeilijk is in het financieel statuut een strikte scheiding aan te brengen. Daarenboven wordt aangevoerd dat een aantal van de zogenoemde additionele kosten die niet door de civiele lijst worden gedragen - zoals bv. de beveiligingskosten - tot het normale takenpakket van die andere overheden behoren, die zij normalerwijze niet aanrekenen. En ten slotte wordt ook aangegeven dat de kostprijs van de Belgische monarchie zeer redelijk is in vergelijking met andere monarchieën en republieken. ${ }^{373}$ Dit alles neemt echter niet weg dat de kern van de kritiek overeind blijft. Een meer doorzichtige en rechtszekere regeling van de financiële aspecten van het koningschap is wenselijk. Net zoals in Nederland zou de civiele lijst van de Koning een 'salarisdeel' en een 'onkostendeel' kunnen bevatten. Voor dat laatste zou de ministeriële verantwoordelijkheid moeten gelden en zouden regels inzake transparantie en controle moeten worden nageleefd. ${ }^{374}$

-IIo. Het is een traditie bijna zo oud als Belgische Staat, dat aan koninklijke prinsen en prinsessen dotaties worden toegekend. ${ }^{375}$ Anders dan voor de civiele lijst van de Koning is dit weliswaar niet in de Grondwet zelf voorzien. De wetgever is vrij ze al dan niet toe te kennen. ${ }^{37}$ Hij moet de opportuniteit ervan beoordelen en desgevallend zowel de begunstigden als het bedrag ervan vaststellen. De dotaties kunnen bij gewone meerderheid worden verhoogd, verlaagd en ook weer afgeschaft. Ze worden beschouwd als een vergoeding voor de onkosten die leden van de koninklijke familie maken bij de vertegenwoordigingstaken die zij uitvoeren. Het gaat bijgevolg niet om een inkomen waarop personenbelasting wordt betaald. Vier leden van de koninklijke familie ontvangen thans een dotatie, koningin-weduwe Fabiola, 377 kroonprins

372 Zie over de vraag of de civiele lijst toch niet als een inkomen van de Koning kan worden beschouwd, waarop dan ook inkomstenbelastingen zouden verschuldigd zijn: K. Stangherlin, Le patrimoine royale, La Charte, 2004, p. 72-77.

373 Y. Monette, Métier de Roi de A à Z, Brussel, 2002, p. 45 (coût de la monarchie et de la république).

$374 \mathrm{Zie}$ voor een voorstel in die zin het wetsvoorstel van de h. Francken c.s. wat de bezoldiging van de leden van de Koninklijke familie betreft, Parl.St., Kamer, 20I0-20II, Doc 53, I3382/oor. Het voorstel houdt één globale regeling in voor de civiele lijst van de koning en voor de dotaties aan de weduwe of de weduwenaar van het staatshoofd en de troonopvolger. Aangezien het voorstel de huidige civiele lijst van de koning aanpast, staat het op gespannen voet met artikel 89 van de Grondwet.

375 Zie het verslag 'Dotaties aan leden van de Koninklijke familie', Parl. St., Senaat, 2008-2009, 4-I335/I.

376 Ze worden geacht op artikel I79 van de Grondwet gebaseerd te zijn.

377 Bij wet van I6 november 1993 werd aan koningin-weduwe Fabiola een dotatie van 45.000.00o fr. (I.II5.520 euro) toegekend. Door de koppeling aan de index van de consumptieprijzen, is deze thans opgelopen tot I, 4 miljoen euro. 
Filip,,$^{378}$ prinses Astrid ${ }^{379}$ en prins Laurent. ${ }^{380}$ Die laatste dotatie stuitte op heel wat weerstand. Laurent was bij de toekenning tiende in de lijn van de troonopvolging. Vele kamerleden vonden het geenszins vanzelfsprekend dat aan alle kinderen van de Koning een dotatie werd toegekend. Ze drongen aan op een globale regeling, waarin ook coherente criteria werden bepaald. Andere kamerleden benadrukten de gelijkheid van de kinderen van de Koning. De dotatie werd uiteindelijk met een ruime meerderheid goedgekeurd, nadat de regering had toegezegd haar medewerking te verlenen aan het uitwerken van een wetsvoorstel met 'een adequate regeling van de problematiek van de civiele lijst van de koning en de dotaties van de leden van de Koninklijke familie. ${ }^{381}$ In de schoot van de Senaat werd er een werkgroep 'Dotaties aan leden van de Koninklijke Familie' opgericht ${ }^{382}$ en die deed in 2009 een aantal aanbevelingen, die naar verluidt discreet het fiat kregen van Laken. ${ }^{883}$ In de toekomst, vanaf de regeerperiode van de opvolger van Albert II, ${ }^{3{ }^{8}} \mathrm{zal}$ nog alleen de afgetreden koning of koningin, de weduwe of weduwenaar van een overleden vorst en de vermoedelijke troonopvolger een dotatie krijgen. De dotatie van de troonopvolger zal uit twee delen bestaan: een inkomen en een vergoeding voor onkosten. Over de aanwending van dit laatste deel zal een controle worden georganiseerd door de Eerste voorzitter van het Rekenhof. De Senaat vroeg de regering om haar aanbevelingen in 'een wettelijk regeling om te zetten'. Dat is vooralsnog niet gebeurd. De recente incidenten rond de reis van prins Laurent naar Kongo, tegen het advies van de regering in, hebben inmiddels tot nieuwe ontwikkelingen geleid. De dotatie zou een voorwaardelijk karakter krijgen. De prins zou ze verliezen indien hij de afspraken in verband met onder meer zijn reizen naar het buitenland niet zou naleven. ${ }^{35}$ De voorzitters van Kamer en Senaat bereiden terzake een wetsvoorstel voor. ${ }^{86}$

\section{Besluit}

-III. Bij de aanvang van de twintigste eeuw telde Europa 2I monarchieën..$^{387} 94 \%$ van het grondgebied werd door monarchen geregeerd. Alleen Frankrijk, Portugal

378 Bij wet van I6 november 1993 werd aan prins Filips een dotatie van 13.500 .000 fr. toegekend. Naar aanleiding van zijn huwelijk werd ze bij wet van 7 mei 2000 opgetrokken tot 31.800.000 fr. (788.30r euro). Door de koppeling aan de index bedraagt deze dotatie thans 920.000 euro.

379 Bij wet van 7 mei 2000 werd aan prinses Astrid een jaarlijkse dotatie van II.00o.00o fr. (272.682 euro) toegekend. Door de koppeling aan de index bedraagt deze dotatie thans 320.000 euro.

$380 \mathrm{Bij}$ wet van $\mathrm{I} 3$ november $200 \mathrm{I}$ werd aan prins Laurent een jaarlijkse dotatie van 272.682 euro toegekend. Door de koppeling aan de index bedraagt dit bedrag thans 306.000 euro.

38I Parl. St., Senaat, 200I-2002, 2-833/7, p. I.

382 Parl. Hand., Senaat, 200I-2002, 25 oktober 200I, 2-I55.

383 Zie het verslag 'Dotaties aan leden van de Koninklijke familie', Parl. St., Senaat, 2008-2009, 4-I335/I, p. 92-93.

384 De dotaties van prinses Astrid en prinses Laurent zouden behouden blijven. Zie F. Delpéree, Parl. Hand., Senaat, 2008-2009, 9 juli 2009, 4-83, p. 39.

385 Zie supra nr. 89 .

386 'Flahaut en Pieters pakken dotaties aan', De Morgen, I2 april $201 \mathrm{I}$.

387 Het keizerrijk Duitsland rekenen we daarbij slechts als één monarchie en we houden geen rekening met de vier koninkrijken, de zes groothertogdommen, de vijf hertogdommen en de zeven vorstendommen die er deel van uitmaakten. 
en Zwitserland waren republieken. ${ }^{38}$ Vandaag zijn er nog slechts acht Europese staten met een monarchie: België, Nederland en Luxemburg, het Verenigd Koninkrijk en Spanje en drie Scandinavische landen, Denemarken, Noorwegen en Zweden. ${ }^{389}$ Deze monarchieën overleefden doordat ze, in de terminologie van Bagehot, bereid waren zich terug te plooien op hun 'dignified functions' en hun 'effective functions' te beperken tot het uitoefenen van invloed, niet van macht. 'De verzwakking van de monarchie heeft de monarchie in stand gehouden', schrijft Schoo terecht. ${ }^{390}$

-II2. Republikeinen denken dat de monarchie, sowieso, gedoemd is om te verdwijnen. Dat het staatshoofd zijn positie ontleent aan het toeval van de geboorte en niet aan de wil van het volk, staat voor hen haaks op de democratie en het gelijkheidsideaal van de Franse Revolutie. Of zoals de Nederlandse socialist Troelstra het ooit uitdrukte: 'Erfelijkheid moge een geschikt leidend beginsel zijn voor paard- en rundveestamboeken, voor het bekleden van publieke ambten kan het geen leidraad geven. ${ }^{391}$ Het koningschap is inderdaad geen ambt dat kan worden nagestreefd en dat, zoals een politiek mandaat, kan worden veroverd door in de volksgunst te raken, dankzij bekwaamheid en verdienste, handigheid en overtuigingskracht, talent en steun van drukkingsgroepen, media, kapitaalverstrekkers en, last but not least, oligarchisch gestructureerde politieke partijen. De monarchie is dus inderdaad een schoonheidsfout op het blazoen van de democratie. Maar misschien heeft het daardoor ook een voordeel. Dankzij de erfelijkheid van het koningschap kan het staatshoofd makkelijker neutraal zijn, de talentegenstellingen overstijgen, boven de partijen staan en daardoor de verbondenheid van de burgers van het land tot uiting brengen. In die symbolische functie scoren presidenten - verkozen of niet verkozen - vaak minder goed. Hoezeer ze ook hun best doen, ze komen voort uit partijen en kunnen dat nooit helemaal doen vergeten. De Koning is daarenboven inderdaad niet democratisch verkozen maar of hij daardoor antidemocratisch dan wel a-democratisch is, hangt geheel af van de rol die hem wordt toebedeeld. De monarchie is grondwettelijk verankerd en met de parlementaire democratie verstrengeld. De Koning vervult zijn rol binnen de krijtlijnen van de grondwet en onder de verantwoordelijkheid van zijn ministers. Van persoonlijke macht is er geen sprake. Hij staat weliswaar in voor de vorming van de regering. De analyse van de crisissen van 2007 en 20I0-20II toont echter aan dat zijn sturend vermogen nauwelijks kan worden onderschat. Hij beschikt ook over Bagehots drie R's. De invloed die hij daardoor op het beleid kan uitoefenen, reikt evenwel niet verder dan de ministers het toelaten.

388 We laten de dwergstaten Andorra en San Marino buiten beschouwing.

389 We laten de dwergstaten Liechtenstein en Monaco buiten beschouwing.

390 H.J. Schoo, 'Hedendaags republicanisme. Een oud politiek idee in de herkansing', in R. Meijer en H.J. Schoo (red.), De Monarchie. Staatsrecht, volksgunst en het Huis van Oranje, Amsterdam, Prometheus, 2002, 212.

39I F. Van den Bergh, 'Sire, ons hart verkrijgt gij nooit', in T. Roodewijn (red.), De Republiek der Nederlanden. Pleidooien voor het afschaffen van de monarchie, Amsterdam, De Bezige Bij, I998, p. I2I. 
'Royalty is not essential...zolang politici hun verantwoordelijkheid nemen', schreef Rehwinkel terecht. ${ }^{392}$

-II3. De geschiedenis leert dat het 'ideaal van de democratie' landen nooit heeft doen overgaan op een republikeinse staatsvorm. Een overgang naar de republiek heeft zich alleen voorgedaan wanneer de monarchie niet langer houdbaar was, na een revolutie (Rusland), een oorlog (Duitsland, Oostenrijk-Hongarije, Turkije), of een fatal error van de Koning (Griekenland, Italië), waardoor het koningshuis bij de bevolking zijn krediet verloor. ${ }^{393}$ In België was het na de Tweede Wereldoorlog, door de houding van Leopold III, bijna zover. Een dergelijke crisis hangt op dit ogenblik niet in de lucht. Een meerderheid van de bevolking aanvaardt de monarchie nog steeds. Er is daarbij ook sprake van de wijsheid dat het vooral theoretici zijn die schrijven op een schone lei, maar dat in de praktijk de lei niet schoon is, maar beschreven door de geschiedenis. ${ }^{394}$

-II4. Dit alles mag ons echter niet doen verhelen dat de crisis waarin de Belgische Staat thans verkeert, een crisis van het staatshoofd tot gevolg kan hebben. De Koning is immers bij uitstek het symbool van de eenheid en de continuïteit van de staat. Als die staat vastvaart en door een aanzienlijk deel van de (Vlaamse) politieke klasse wordt betwist, komt ook de functie van het staatshoofd zelf onder druk te staan. In dit preadvies hebben we erop gewezen dat de Koning in het politiek strijdgewoel terecht komt wanneer hij als een 'believer' de eenheid van het land verdedigt en daardoor de 'non believers' tegen zich in het harnas jaagt. Een paradoxale situatie voor een staatshoofd. We hebben er ook op gewezen dat de rol die de Koning in 2007 en 20I0-20II speelde in de zoektocht naar een vergelijk tussen Vlamingen en Franstaligen over de staatshervorming, hem er meer dan eens toe heeft gebracht in de politieke arena af te dalen, ten koste van een strikte neutraliteit en met meteen ook verwijten van partijdigheid tot gevolg. De recente schendingen van de vertrouwelijkheid van de gesprekken met de Koning wijzen erop dat een aantal politici - en niet de minste - al dan niet met republikeinse intenties, niet meer het respect opbrengen dat nodig is om het staatshoofd toe te laten zijn taak te vervullen. Er zijn aanwijzingen dat het aanzien van het koningschap ook in de publieke opinie taant. Uit een Ipsos-opiniepeiling bij 2000 mensen in maart 2010 blijkt dat een meerderheid van $62 \%$ van de Belgen nog steeds voor het behoud van de monarchie is. Betekenisvol is echter dat $75 \%$ van de Franstaligen het koningshuis nog steunt, tegen slechts $54 \%$ van de Vlamingen. ${ }^{395}$ Een vorst die verplicht is voortdurend initiatieven te nemen die hem in politiek vaarwater brengen, dreigt teken van verdeeldheid te worden. Zijn

392 P. Rehwinkel, 'Royalty is not essential... zolang politici hun verantwoordelijkheid nemen', in R. Meijer en H.J. Schoo (red.), De Monarchie. Staatsrecht, volksgunst en het Huis van Oranje, Amsterdam, Prometheus, 2002, p. 73-roo.

393 V. Bogdanor, The monarchy and the constitution, Oxford, Clarendon Press, I995, p. 299.

394 T. Roodewijn (red.), De Republiek der Nederlanden. Pleidooien voor het afschaffen van de monarchie, Amsterdam, De Bezige Bij, I998, p. I2I.

395 S. Samyn en M. Buxant, Koning zonder land. De toekomst van de Belgische monarchie in woelige tijden, Amsterdam, De Bezige Bij, 20II, p. I67-I68. 
symbolische rol om de eenheid van de Staat en van de Natie te vertegenwoordigen kan dan in het gedrang komen. Of om het in Bagehot's termen te stellen: een staatshoofd kan de 'dignified functions' slechts echt uitoefenen, indien de 'efficient functions' door anderen worden vervuld. De Britse constitutionalist Vernon Bogdanor schreef zelfs: "when he or she exercises the "efficient" functions, the head of state will cease to be able to represent all the people; he or she will be representing the particular cross-section who agree with his or her activities. ${ }^{396}$

-II5. Zowel in België als in Nederland is er inmiddels discussie ontstaan over het koningschap. In ons land hebben verschillende politieke partijen zich uitgesproken voor een protocollaire, ceremoniële monarchie. De koning zou zich dan dienen terug te buigen op zijn rol als a-politiek en neutraal staatshoofd dat de eenheid en de continuïteit van de staat vertegenwoordigt zonder nog politieke taken op zich te nemen. De hamvraag is echter of het complexe Belgische staatsbestel geen behoefte heeft aan de rol die de Koning steeds heeft gespeeld bij de vorming van de regering en of er evenwaardige alternatieven bestaan. Indien België ooit zelf weer in rustiger vaarwater terecht komt, zal misschien ook de koning opnieuw een minder uitgesproken rol kunnen spelen. Tevens rijst de vraag of het wel wenselijk is het staatshoofd ook de drie R's van Bagehot te ontzeggen. In Nederland wordt de stelling verdedigd dat door het staatshoofd buiten de regering te plaatsen de kans groter wordt dat hij 'zijn gang gaat, ook publiekelijk'. Buiten de regering heeft hij immers niet meer 'de morele verantwoordelijkheid tegenover de andere leden van de regering om hen niet in de problemen te brengen met onbesuisde uitlatingen.' 'Wie de macht van de koning beperkt wil houden, moet hem dan ook binnen de regering houden', schrijft Lunshof.397 Of anders uitgedrukt: 'het losweken van het koningschap van de regeringsfunctie kan onder omstandigheden leiden tot een onwenselijke "politisering" van de monarchie', aldus Elzinga..$^{39^{8}}$ Wie nadenkt over de invoering van een protocollaire monarchie zal zich over deze vragen dienen te buigen.

-II6. De vraag rijst ten slotte of het misschien niet wenselijk zou zijn om, net als in Nederland, ook in België de constitutionele bepalingen over de monarchie onder het stof vandaan te halen, door de machten niet langer aan de Koning toe te wijzen, maar aan de regering, waarvan de Koning en de ministers deel uit maken. Dat zou weliswaar niet veel veranderen, maar het is het overwegen waard. Ook al is een grondwet niet descriptief, maar normatief, het is toch best dat ze geen verkeerde indruk wekt over de machtsuitoefening. Een constitutionele facelift, die toelaat om de positie van de Koning, respectievelijk de ministers correcter in te schatten is niet overbodig. Een alternatief kan zijn om de actuele draagwijdte van de grondwettelijke

396 V. Bogdanor, The monarchy and the Constitution, I995, Oxford University Press, p. 62-63.

397 K. Lunshof, 'Republikeinse denkfouten. De monarchie als ware democratie', in R. Meijer en H.J. Schoo (red.), De Monarchie. Staatsrecht, volksgunst en het Huis van Oranje, Amsterdam, Prometheus, 2002, p. 25I.

398 D.J. Elzinga, "Monarchie en constitutioneel neutrum. Over de betekenis van de "pouvoir neutre" in de Nederlandse democratie', in D.J. Elzinga, De Nederlandse constitutionele monarchie in een veranderend Europa, Kluwer, Alpen aan de Rijn, 2006, p. I9. 
bepalingen, gewoonten en de conventies over de monarchie, bij het aantreden van de nieuwe Koning, in een officieel document te verduidelijken. Verschillende pistes kunnen worden gevolgd: de eerste minister kan namens de regering een notitie over het hedendaags koningschap aan de Kamer voorleggen waarin de actuele invulling van monarchie en democratie wordt uiteengezet. Een dergelijke demarche zou perfect kunnen. Het gaat er dan immers niet om de grondwet te wijzigen en zelfs niet om een authentieke interpretatie ervan te geven. De regering geeft slechts aan van welke invulling van de grondwettelijke bepalingen, gewoonten en conventies over de monarchie, zij uitgaat bij het dragen van de ministeriële verantwoordelijkheid. Zij kan vervolgens daarover met het parlement in debat treden. De Nederlandse ervaring met de notitie van minister-president Kok in 2000 en met de brief van ministerpresident Rutte in $2011^{399}$ kan hier tot voorbeeld strekken. Desgevallend zou ook, zoals in I949, een commissie in het leven kunnen worden geroepen, om opnieuw de prerogatieven van het hedendaagse koningschap helder te verwoorden. Ook de financiële aspecten - de civiele lijst en de dotaties van de leden van de koninklijke familie - zouden op een heldere leest moeten worden geschoeid. Het zou een frisse start van een nieuw koningschap kunnen mogelijk maken.

399 Zie supra voetnoot I4. 